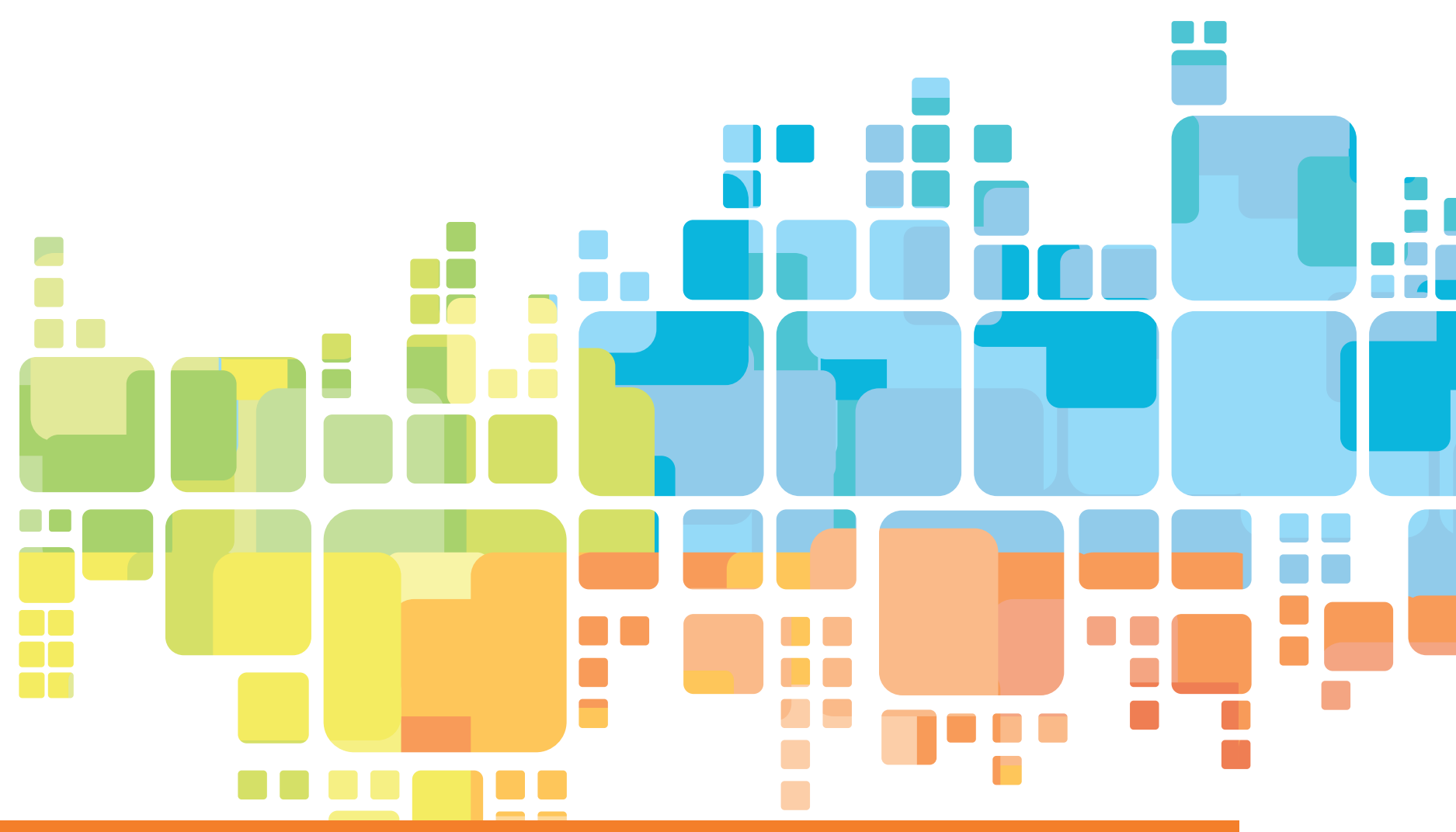

\title{
LAO PEOPLE'S
}

DEMOCRATIC REPUBLIC

ENERGY SECTOR ASSESSMENT,

STRATEGY, AND ROAD MAP

NOVEMBER 2019 


\section{LAO PEOPLE'S \\ DEMOCRATIC REPUBLIC ENERGY SECTOR ASSESSMENT, STRATEGY, AND ROAD MAP}

NOVEMBER 2019 
(C) 2019 Asian Development Bank 6 ADB Avenue, Mandaluyong City, 1550 Metro Manila, Philippines

Tel +632 8632 4444; Fax +63286362444

www.adb.org

Some rights reserved. Published in 2019.

ISBN 978-92-9261-894-o (print), 978-92-9261-895-7 (electronic)

Publication Stock No. TCS190567

DOI: http://dx.doi.org/10.22617/TCS190567

The views expressed in this publication are those of the authors and do not necessarily reflect the views and policies of the Asian Development Bank (ADB) or its Board of Governors or the governments they represent.

ADB does not guarantee the accuracy of the data included in this publication and accepts no responsibility for any consequence of their use. The mention of specific companies or products of manufacturers does not imply that they are endorsed or recommended by ADB in preference to others of a similar nature that are not mentioned.

By making any designation of or reference to a particular territory or geographic area, or by using the term "country" in this document, $A D B$ does not intend to make any judgments as to the legal or other status of any territory or area.

This work is available under the Creative Commons Attribution 3.0 IGO license (CC BY 3.0 IGO)

https://creativecommons.org/licenses/by/3.o/igo/. By using the content of this publication, you agree to be bound by the terms of this license. For attribution, translations, adaptations, and permissions, please read the provisions and terms of use at https://www.adb.org/terms-use\#openaccess.

This CC license does not apply to non-ADB copyright materials in this publication. If the material is attributed to another source, please contact the copyright owner or publisher of that source for permission to reproduce it. $\mathrm{ADB}$ cannot be held liable for any claims that arise as a result of your use of the material.

Please contact pubsmarketing@adb.org if you have questions or comments with respect to content, or if you wish to obtain copyright permission for your intended use that does not fall within these terms, or for permission to use the ADB logo.

Corrigenda to ADB publications may be found at http://www.adb.org/publications/corrigenda.

Notes:

In this publication, “\$” refers to United States dollars.

ADB recognizes "Laos" as the Lao People's Democratic Republic, "Korea" as the Republic of Korea, and

"Vietnam" as Viet Nam.

Cover design by Mike Cortes. 


\section{Contents}

Tables, Figures, and Maps $\quad \mathrm{v}$

Acknowledgments vii

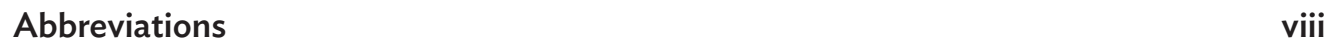

$\begin{array}{ll}\text { Weights and Measures } & \text { ix }\end{array}$

$\begin{array}{ll}\text { Currency Equivalents } & \text { ix }\end{array}$

$\begin{array}{llr}1 & \text { Introduction } & 1\end{array}$

2 Overall Sector Context 2

2.1 Energy Resources 5

$\begin{array}{ll}2.2 \text { Energy Balance } & 10\end{array}$

3 Institutional Context 12

3.1 Government Institutions in the Power Sector $\quad 12$

3.2 State-Owned Enterprises 14

3.3 Role of the Private Sector 16

3.4 Legal Framework 19

3.5 Policy Evolution 20

4 Core Sector Issues $\quad 22$

4.1 Power Capacity and Generation $\quad 22$

4.2 Domestic Demand 31

4.3 Transmission and Cross-Border Exports $\quad 35$

4.4 Distribution and Tariffs 40

4.5 Climate Change and the Environment 42

4.6 Electrification and Access to Electricity 47

$\begin{array}{ll}4.7 \text { Energy Efficiency } & 50\end{array}$

5 Power Sector Constraints $\quad \mathbf{5 2}$

5.1 Financial Sustainability of Électricité du Laos 52

5.2 Transmission Infrastructure Requirements $\quad 57$

5.3 Regulation and the Need for Institutional Capacity Building 61

5.4 Realizing Hydropower Potential 63 
6 Sector Strategy $\quad 64$

6.1 Government Sector Strategy 64

6.2 ADB Sector Support Program and Experience 65

6.3 ADB Self-Evaluation 66

6.4 ADB Lessons Learned $\quad 66$

6.5 Other Development Partner Support $\quad 67$

6.6 ADB Sector Forward Strategy 68

6.7 Lending and Non-Lending Program and Resource Needs 69

$\begin{array}{ll}6.8 \text { Risks and Assumptions } & 70\end{array}$

7 Sector Road Map and Results Framework, 2018-2023 72

Appendixes

1 Energy Sector Problem Tree $\quad 73$

2 Power Plants of the Lao People's Democratic Republic, as of 2017

3 Key Transmission Projects Proposed in the Lao People's Democratic Republic 76

4 Pipeline of Hydropower Projects of the Lao People's Democratic Republic 77

5 Laws and Regulations for Power Project Development 80 in the Lao People's Democratic Republic 


\section{Tables, Figures, and Maps}

\section{Tables}

1 Summary of Lao Holding State Enterprise Project Investments, 15 as of December 2017

2 Current and Official Proposed Future Plant Type Mix in 30 the Lao People's Democratic Republic

3 Renewable Energy Development Targets for 31 the Lao People's Democratic Republic

$4 \quad$ System Average Interruption Duration Index and System Average 41 Interruption Frequency Index within Southeast Asia, 2013-2015

5 Intended Mitigation Activities to be Implemented by 44 the Lao People's Democratic Republic in 2015-2020

$6 \quad$ Électricité du Laos Key Financial Ratios 53

7 EDL-Generation Public Company Key Financial Ratios 54

8 Regional Domestic Peak and Domestic Installed Capacity for 60 the Lao People's Democratic Republic, 2017 and 2030

9 ADB Loan and Technical Assistance Support to the Power Sector in 65 the Lao People's Democratic Republic, since 2005

\section{Figures}

$1 \quad$ Energy Intensity in the Lao People's Democratic Republic 4 and Selected Southeast Asian Nations, 2005-2016

2 Historical Economic Growth and Per Capita Income in the Lao People's Democratic Republic

3 Visualization of Annual Runoff and Precipitation in the Mekong River 7

4 Solar Potential of Selected Members of the Association of Southeast 8 Asian Nations

$5 \quad$ Historical Total Energy Supply by Source and Final Energy Use by Sector in 11 the Lao People's Democratic Republic, 2012-2016

6 Structure of the Power Sector in the Lao People's Democratic Republic 13

7 Energy Generation Capacity by Sponsor Nation 19

8 Domestic and Export-Oriented Installed Capacity in 23 the Lao People's Democratic Republic, as of 2017

9 Power Capacity in the Lao People's Democratic Republic, 23 by Domestic Consumption and Export, and by Fuel Source, 2017
Past Domestic Generation, Short-Term Exports and Imports

$\begin{array}{lll}10 & \text { Past Domestic Generation, Short-Term Exports and Imports } & 24 \\ 11 & \text { Rainfall Trends in the Lao People's Democratic Republic } & 25\end{array}$

12 Power Capacity for Domestic Consumption and the Adjusted Reserve 26 Margin in the Lao People's Democratic Republic 
13 Outlook for Generation Serving the Domestic Market in 27 the Lao People's Democratic Republic

14 Export Power Capacity Outlook for the Lao People's Democratic Republic 28

15 Contracted Power Exports of the Lao People's Democratic Republic 29

16 Electricity Consumption in the Lao People's Democratic Republic, 32 by End-User Type, 2010-2017

17 Diurnal Demand Profile in Four Grids of the Lao People's 33

Democratic Republic

18 Electricity Imports from Neighboring Countries to the Lao People's 34

Democratic Republic in 2017 and Average Precipitation, 1960-2005

19 Transmission and Distribution Grid Losses in the Lao People's 36

Democratic Republic, 2000-2016

20 Regional Peak Demand and Installed Capacity for Domestic 37

Consumption in the Lao People's Democratic Republic, 2017

21 Tariff Trends of Key Customer Classes and Average Cost of Supply in 42

the Lao People's Democratic Republic

22 National Electrification Levels in the Lao People's Democratic Republic 48

23 Électricité du Laos Recurring Revenues, Costs, and Profit/Loss 53

24 Électricité du Laos Tariffs, 2017

25 Profile of Global Average Power Tariffs 56

Maps

1 Transmission Network of the Lao People's Democratic Republic 3

2 Électricité du Laos Near-Term Transmission Expansion Plans in the North, 39 Central 1, Central 2, and Southern Grids

3 Electrification Rate in the Lao People's Democratic Republic, by Province, 49 as of 2017

4 Électricité du Laos Long-Term 500-Kilovolt Transmission Plan 


\section{Acknowledgments}

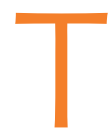

his report was prepared by a team from The Lantau Group under the technical supervision of Pradeep Tharakan, principal climate change specialist from the Energy Division, Southeast Asia Department, of the Asian Development Bank (ADB). Additional guidance and support were provided by Andrew Jeffries (director, Energy Division, Southeast Asia Department, ADB). The team wishes to thank Yongping Zhai, chief, Energy Sector Group, Sustainable Development and Climate Change Department, ADB, as the report's peer reviewer; Julie Casabianca, consultant, ADB, who provided contributions; and Elmar Elbling, consultant, $A D B$, who helped guide the final preparation of the report.

The team would also like to thank the Department of Energy Policy and Planning, Ministry of Energy and Mines, Électricité du Laos (EDL), EDL-Generation Public Company of the Lao People's Democratic Republic (Lao PDR), and development partners for their inputs and discussions during the preparation of the report. The team is also grateful to ADB's Lao PDR Resident Mission and Department of Communications for their support. 


\section{Abbreviations}

$\begin{array}{ll}\text { ADB } & \text { Asian Development Bank } \\ \text { AFD } & \text { Agence Française de Développement } \\ \text { ASEAN } & \text { Association of Southeast Asian Nations } \\ \text { ASR } & \text { assessment, strategy, and road map } \\ \text { BOT } & \text { build-operate-transfer } \\ \text { CAGR } & \text { compound annual growth rate } \\ \text { CPS } & \text { country partnership strategy } \\ \text { DEB } & \text { Department of Energy Business } \\ \text { EDL } & \text { Électricité du Laos } \\ \text { EDL-Gen } & \text { EDL-Generation Public Company } \\ \text { EEC } & \text { energy efficiency and conservation } \\ \text { EGAT } & \text { Electricity Generating Authority of Thailand } \\ \text { FDI } & \text { foreign direct investment } \\ \text { GDP } & \text { gross domestic product } \\ \text { GMS } & \text { Greater Mekong Subregion } \\ \text { INDC } & \text { Intended Nationally Determined Contribution } \\ \text { IPP } & \text { independent power producer } \\ \text { JICA } & \text { Japan International Cooperation Agency } \\ \text { Lao PDR } & \text { Lao People's Democratic Republic } \\ \text { LHSE } & \text { Lao Holding State Enterprise } \\ \text { MEM } & \text { Ministry of Energy and Mines } \\ \text { MOU } & \text { memorandum of understanding } \\ \text { NSEDP } & \text { National Socio-Economic Development Plan } \\ \text { PDP } & \text { power development plan } \\ \text { PEA } & \text { Provincial Electricity Authority (Thailand) } \\ \text { PPA } & \text { power purchase agreement } \\ \text { PRC } & \text { People's Republic of China } \\ \text { PV } & \text { photovoltaic } \\ \text { RPTCC } & \text { Regional Power Trade Coordination Committee } \\ \text { SEA } & \text { strategic environmental assessment } \\ \text { SHS } & \text { solar home system } \\ \text { SOE } & \text { state-owned enterprise } \\ \text { USAID } & \text { United States Agency for International Development } \\ & \end{array}$




\section{Weights and Measures}

$\begin{array}{ll}\text { GW } & \text { gigawatt } \\ \text { GWh } & \text { gigawatt-hour } \\ \text { km } & \text { kilometer } \\ \text { kV } & \text { kilovolt } \\ \text { kWh } & \text { kilowatt-hour } \\ \text { kWp } & \text { kilowatt-peak } \\ \text { mt } & \text { million ton } \\ \text { MTOE } & \text { million tons of oil equivalent } \\ \text { MW } & \text { megawatt } \\ \text { MWh } & \text { megawatt-hour } \\ \text { TWh } & \text { terawatt-hour }\end{array}$

\section{Currency Equivalents}

(as of 5 September 2019)

$\begin{array}{lll}\text { Currency unit } & - & \text { kip }(\mathrm{KN}) \\ \mathrm{KN} 1.00 & = & \$ 0.00011 \\ \$ 1.00 & = & \mathrm{KN} 8,793.22\end{array}$




\title{
1 Introduction
}

\begin{abstract}
his sector assessment, strategy, and road map (ASR) reviews the state of the energy sector of the Lao People's Democratic Republic (Lao PDR). Consistent with the government's plans and strategy, the ASR proposes supportive actions for the energy sector to be taken by the Asian Development Bank (ADB) during 2019-2022. It also provides sector background information, which will be updated as needed for investment and technical assistance operations. The ASR is a working paper based on a systematic review of the Lao PDR's energy sector and consultations with the government and other development partners.

The ASR is linked with and informs ADB's country partnership strategy (CPS) for the Lao PDR. The current CPS (2017-2020) sets out principles for assistance and partnership between ADB and the Lao PDR. The CPS is aligned with the government's policies and priorities and draws upon ADB's new Strategy 2030.' Published in July 2018, Strategy 2030 outlines a framework for ADB's overall operations for 2030. The ASR will also be used for the preparation of the next CPS (2021-2025).
\end{abstract}




\section{Overall Sector Context}

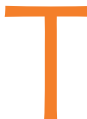

he Lao PDR is a landlocked nation in Southeast Asia with a total land area of 236,800 square kilometers and comprising 18 provinces. ${ }^{2}$ It is characterized by a rugged mountainous topography and the north to south flow of the Mekong River, which straddles much of the country's long western frontier with Thailand. The Lao PDR also shares a border with Viet Nam to the east and adjoins Cambodia, Myanmar, and the Yunnan Province of the People's Republic of China (PRC).

The population of the Lao PDR is one of the smallest in Southeast Asia and, as of July 2017, was estimated to be 7,126,706, having grown at a compound annual growth rate (CAGR) of $1.90 \%$ since $2010 .^{3}$ The Lao PDR is classed as a "lower middle-income country," with per capita gross domestic product (GDP) of $\$ 2,027$ in 2016, from $\$ 621$ in $2006 .{ }^{4}$ Map 1 provides a geographic overview of the country's transmission network, which comprises the northern, central 1, central 2 , and southern regions.

With a GDP of $\$ 17.15$ billion as of 2017, the Lao PDR's economy is the third smallest in Southeast Asia. ${ }^{5}$ Having historically been a centrally planned economy prior to the introduction of the New Economic Mechanism in 1986, it has since developed its agricultural foundation into a market-oriented economy, of which around half is now tied to services (48.02\%); the industrial sector accounts for $32.51 \%$ and the agricultural sector at $19.47 \%$ on a value-added basis. ${ }^{6}$ Given the country's small population, the economy is strongly intertwined with the development and export of natural resources, principally mining, hydropower, and timber extraction industries. ${ }^{7}$

The per capita electricity consumption of the Lao PDR, at 725 kilowatt-hours ( $\mathrm{kWh}$ ) in 2017, is one of the lowest in Southeast Asia. ${ }^{8}$ However, the energy intensity of its economy

K. Kouphokham. 2016. Lao PDR Country Report. In S. Kimura and P. Han, eds. Energy Outlook and Energy Saving Potential in East Asia 2016. Jakarta: Economic Research Institute for ASEAN and East Asia (ERIA). ERIA Research Project Report 2015-5. pp.193-213.

3 World Bank. Population, Total. https://data.worldbank.org/indicator/SP.POP.TOTL?locations=LA (accessed 10 December 2017).

4 ADB. 2017. New ADB-Lao PDR Strategy to Support Inclusive, Sustainable Growth. News from Country Offices. 21 September. https://www.adb.org/news/new-adb-lao-pdr-strategy-support-inclusive-sustainable-growth.

5 International Monetary Fund (IMF). IMF DataMapper. Real GDP Growth. http://www.imf.org/external/datamapper/ (accessed 17 December 2017).

6 World Bank. Economy \& Growth. https://data.worldbank.org/topic/economy-and-growth?locations=LA (accessed 17 December 2017).

7 The mining industry is focused on copper, gold, gypsum, and tin, in particular.

8 In comparison, the latest available per capita electricity consumption (in kWh) of other Southeast Asian countries is as follows: Malaysia (4,303), Thailand (2,547), Viet Nam (1,690), Indonesia (827), the Philippines (718), Myanmar (256), and Cambodia (321), as cited in ADB. 2018. Key Indicators for Asia and the Pacific 2018. Manila. 
Map 1: Transmission Network of the Lao People's Democratic Republic

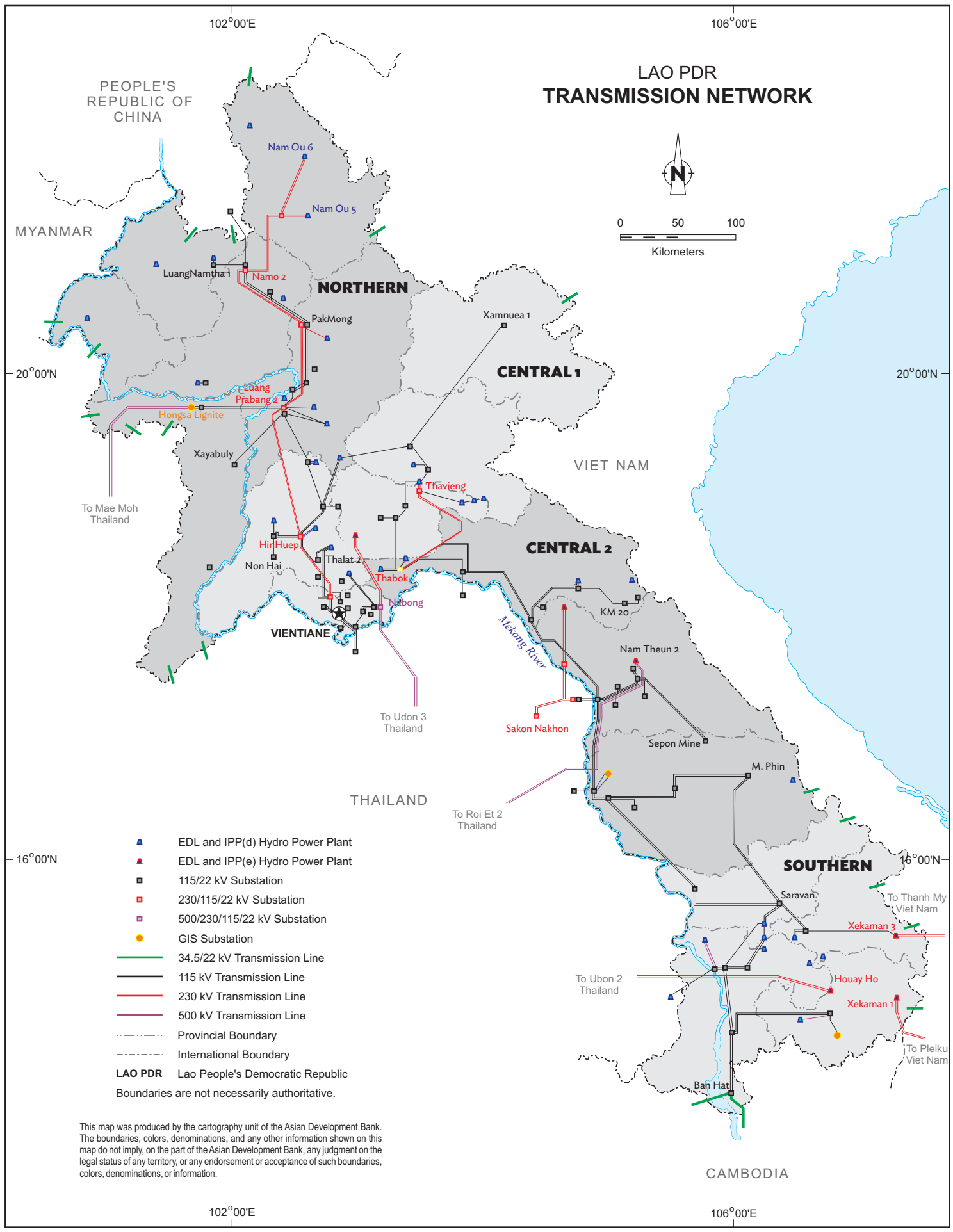

181956A 18LAO ABV

Source: Électricité du Laos. 2017. Electricity Statistics 2016. Vientiane. 
Figure 1: Energy Intensity in the Lao People's Democratic Republic and Selected Southeast Asian Nations, 2005-2016

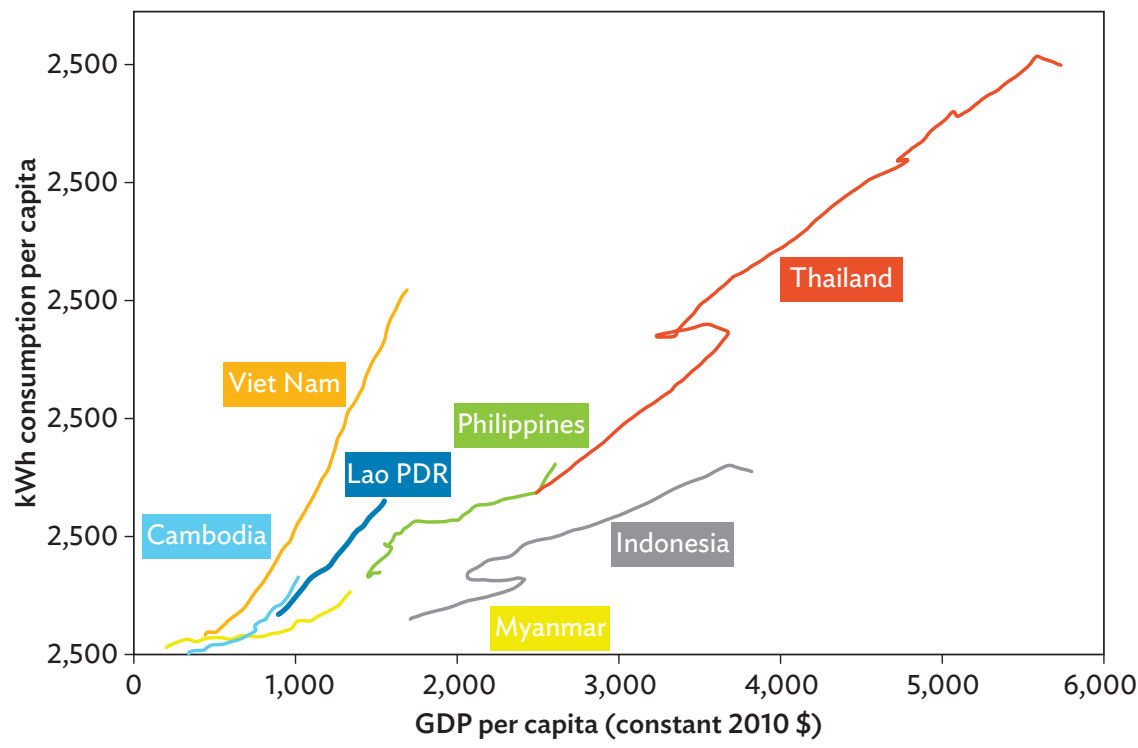

GDP = gross domestic product, $\mathrm{kWh}=$ kilowatt-hour, Lao PDR $=$ Lao People's Democratic Republic . Source: World Bank. World Bank Open Data. https://data.worldbank.org (accessed 18 December 2017); government departments of the respective countries.

is higher than Indonesia, Myanmar, and the Philippines yet lower than Viet Nam as indicated by the steepness of the data series presented in Figure 1. ${ }^{9}$ The Lao PDR also has very low carbon emissions, at 0.30 metric tons per capita in 2014 or $6 \%$ of the global average equivalent of 4.97 metric tons (footnote 9 ).

Notwithstanding its comparatively small size, the economic growth of the Lao PDR in recent years has been robust, with real GDP at an average annual growth rate of 7.67\% between 2010 and 2016 as shown in Figure 2 (footnote 5).

The rate of economic growth is forecast to remain strong-albeit slowing down slightly-in the coming years with an average annual growth rate of $7.02 \%$ from 2018 to 2022 (footnote 5). Growth is expected to be buoyed by the commissioning of new hydropower projects and increased foreign investment, as the Lao PDR has established special economic zones to increase foreign direct investment (FDI) inflows. ${ }^{10}$ The government has prioritized not only the electricity sector but also the agroforestry, tourism, mining, and construction sectors."

9 World Bank. World Bank Open Data. https://data.worldbank.org (accessed 3 September 2018).

10 IMF. 2017. Lao People's Democratic Republic: 2016 Article IV Consultation. IMF Country Report. No. 17/53. Washington, DC.

1 ADB. 2017. Lao PDR: Accelerating Structural Transformation for Inclusive Growth: Country Diagnostic Study. Manila. 
Figure 2: Historical Economic Growth and Per Capita Income in the Lao People's Democratic Republic

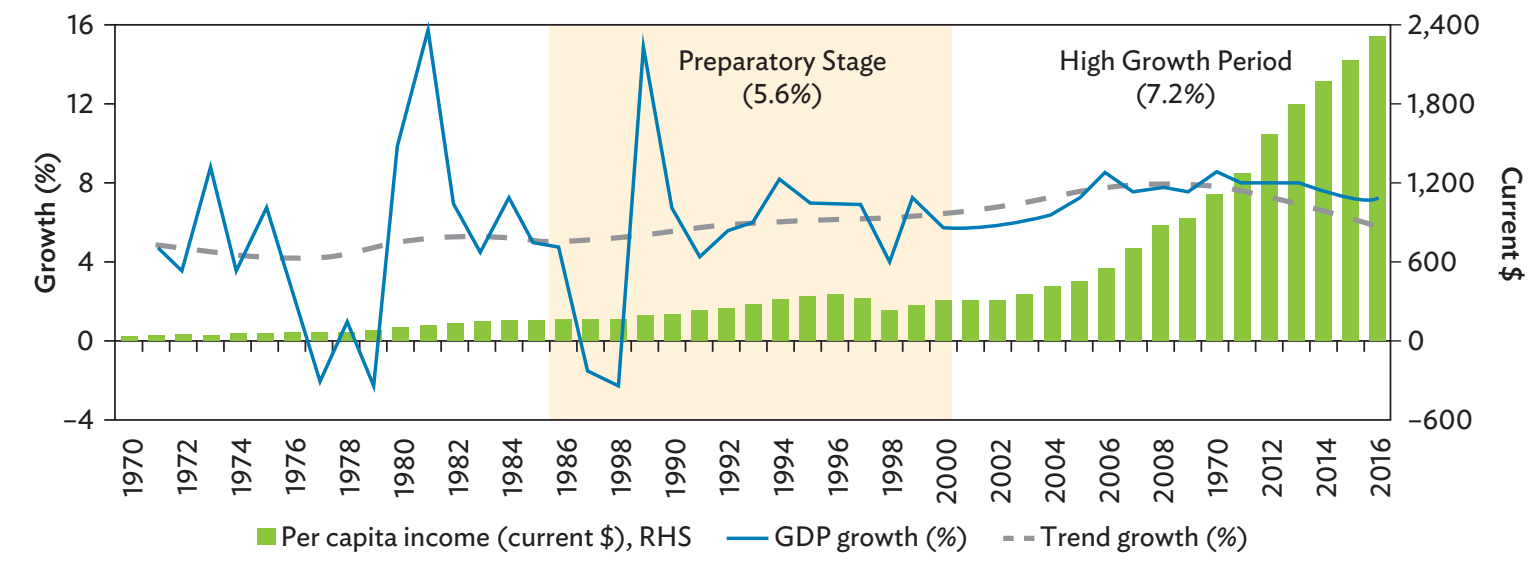

$\mathrm{GDP}=$ gross domestic product, $\mathrm{RHS}=$ right-hand side axis.

Source: ADB. 2017. Lao PDR: Accelerating Structural Transformation for Inclusive Growth: Country Diagnostic Study. Manila.

Despite this positive near- to medium-term economic outlook, some prominent economic institutions - notably the International Monetary Fund (IMF), World Bank, and ADB - have highlighted that the ability of the Lao PDR to achieve sustainable and inclusive economic growth over the longer term will be tied to overcoming structural challenges and risks. These include reducing the current account deficit and lowering external debt-to-GDP and debt service-to-revenue ratios while strengthening public banks to achieve higher capital buffers. The risk of the country facing "external debt distress" is now risen from moderate to high, with the IMF calling for an urgent need for the country to develop a strategy for medium-term debt management, tighten its fiscal policy, and improve public financial management (footnote 10). Indeed, external debt has played a key role in financing capital-intensive hydropower projects.

\subsection{Energy Resources}

Compared with neighboring countries in the Greater Mekong Subregion (GMS), principally Thailand and Viet Nam, the Lao PDR is not blessed with abundant fossil fuel resources. The country relies on imports of close to $100 \%$ of petroleum products, ${ }^{12}$ while estimates of coal reserves range between 600 million tons $(\mathrm{mt})$ and $700 \mathrm{mt}$ and mostly comprise lignite and small amounts of anthracite. ${ }^{13}$ The Lao PDR's lignite resources are concentrated in Hongsa in Xayabuli Province to the northwest, where reserves are estimated to contain greater than $400 \mathrm{mt}$ (footnote 13).

Petroleum products are used by the transport and industrial sectors along with households in off-grid areas. A. Vongsay. 2013. Energy Sector Development in Lao PDR. Presented to Energy Policy Training Course. Tokyo. 24 June-12 July. 
Coal is primarily used by cement factories along with a few small industrial users, with consumption totaling about 300,000 tons per year. ${ }^{14}$ However, this pattern of coal use has changed markedly in recent years following the commissioning of the 1,878-megawatt (MW) lignite-fired thermal plant in Hongsa in 2015, which accounted for $34.9 \%$ of the overall generation mix in $2017 .{ }^{15}$ The majority of the electricity generated from this plant (1,778 MW) is exported to Thailand, and $100 \mathrm{MW}$ is sold to the Lao PDR's state utility, Électricité du Laos (EDL).

Despite having somewhat modest fossil fuel resources, the Lao PDR has a vast hydropower potential owing to its positioning within the Mekong River, high precipitation levels, and mountainous topography that provides high levels of runoff (Figure 3). ${ }^{16}$ The country's exploitable hydro potential is estimated to be $23,000 \mathrm{MW}$, and 5,172 MW of hydropower capacity had been commissioned as of 2017 with several forthcoming projects at varying stages of development (footnote 15).

The ability of the Lao PDR to monetize its vast hydrological resources, both in terms of existing and future hydropower capacity, will have a major bearing on its ambition to be eligible to graduate from least-developed country status by 2024 , in line with its national socioeconomic development plan. ${ }^{17}$

Hydropower makes a significant contribution to the overall economy. The government earns revenue from taxes, royalties, and dividends from EDL and independent power producers (IPPs), and, more broadly, the country benefits from substantial foreign private investment. Indeed, revenues from hydropower are forecast at $1.2 \%$ of GDP in 2018 , with royalties accounting for $0.8 \%$ (footnote 10 ). While hydropower development is expected to drive future economic growth in the Lao PDR, the establishment of new power exchange arrangements will be an important prerequisite to help earn export revenues and to dispatch excess capacity.

Nearly half of the forthcoming hydropower projects in the Lao PDR are earmarked for cross-border exports. The country's central location within the GMS allows it to supply electricity to sizable neighboring markets such as Thailand and Viet Nam; and to a lesser extent, also to Cambodia and Myanmar. The Lao PDR does, however, face challenges on several fronts in order to realize these ambitions. These include the financing burden and social and environmental impact of such projects, the parallel requirement to develop enabling transmission infrastructure, potential competition from cheaper exports from southern PRC where considerable surplus capacity exists, as well as the recent trend of importing countries to shore up their generation mix

14 Japan International Cooperation Agency (JICA); The Institute of Energy Economics, Japan; Electric Power Development Co., Ltd.; Mitsubishi Research Institute, Inc. 2012. Data Collection Study (Preliminary Assessment) on Energy Sector in Lao People's Democratic Republic. Vientiane.

15 Government of the Lao PDR, Ministry of Energy and Mines. 2018. Electricity Statistics 2017. Vientiane. Mekong Flows. Mekong Basin. http://mekongriver.info/mekong-basin.

ADB. 2018. Asian Development Bank Member Fact Sheet: Lao People's Democratic Republic. https://www.adb. org/sites/default/files/publication/27776/lao-2018.pdf. 


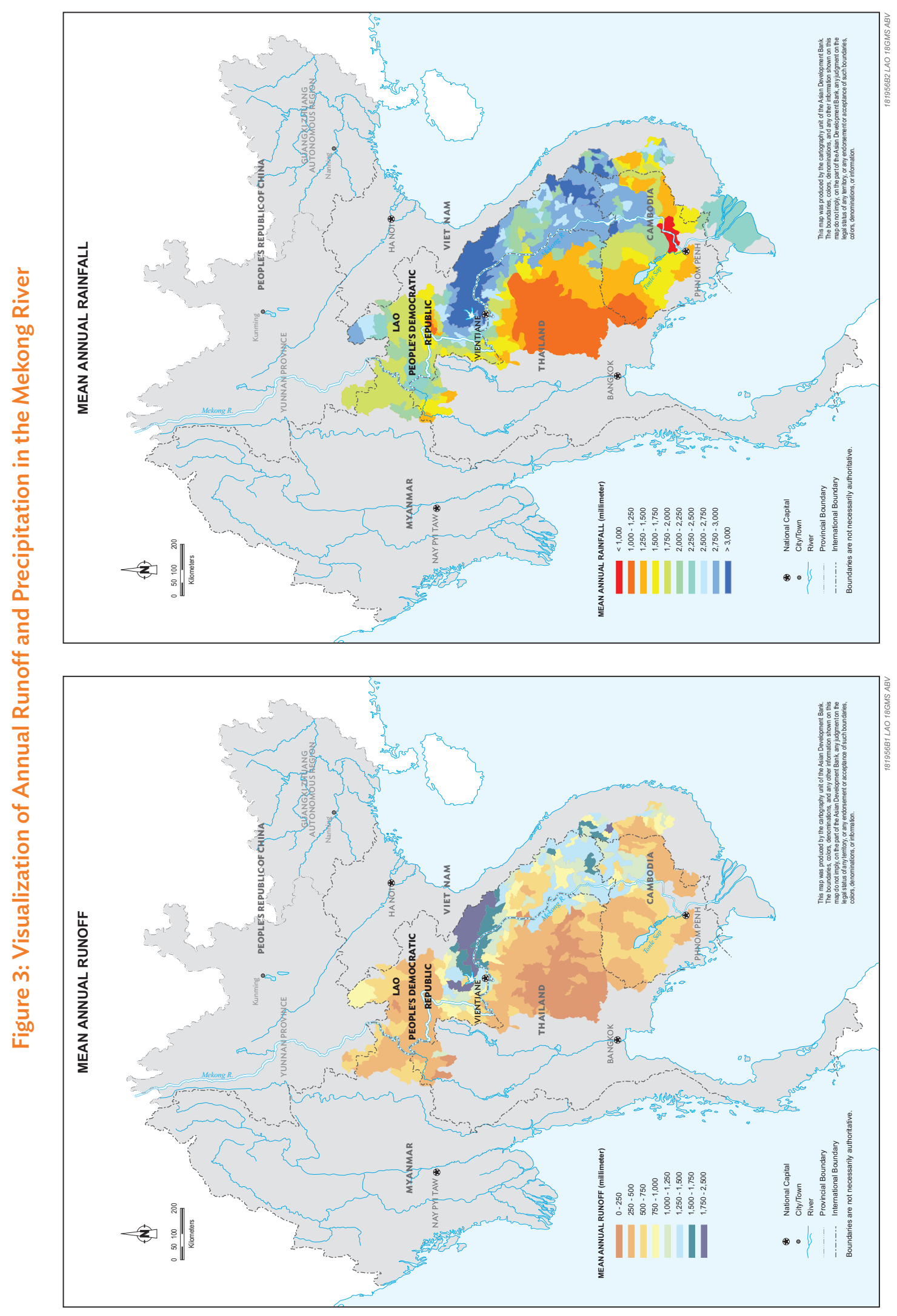

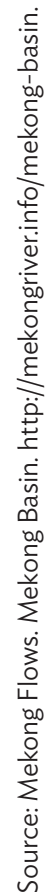


with increased renewable energy and battery storage. ${ }^{18}$ These issues are discussed further in sections 3,4 , and 5 of this report.

The Lao PDR is also endowed with significant resource potential for non-hydro renewables that includes solar, biomass, small or mini-hydro, and wind. Through its Renewable Energy Development Strategy, 2011-2025, the country is seeking to promote non-large hydropower renewable resources to reach a $30 \%$ share of the country's total energy demand by $2025 .{ }^{19}$ Thus far, the commercial-scale application of these renewable generation technologies is still very much in its infancy, limited in part by the absence of a feed-in tariff scheme. Equally, there has been no comprehensive study of the country's overall energy potential that would otherwise allow an integrated approach to the planning and development of the country's energy resources to take place.

Solar potential is estimated to be $4.4 \mathrm{kWh} /$ square meter/day, within a range of 3.6-5.5 $\mathrm{kWh} /$ square meter/day and equating to 1,800-2,000 hours of sunlight per year. ${ }^{20}$ While being more favorable in the south of the country, conditions for solar power are less favorable than most other Association of Southeast Asian Nations (ASEAN)

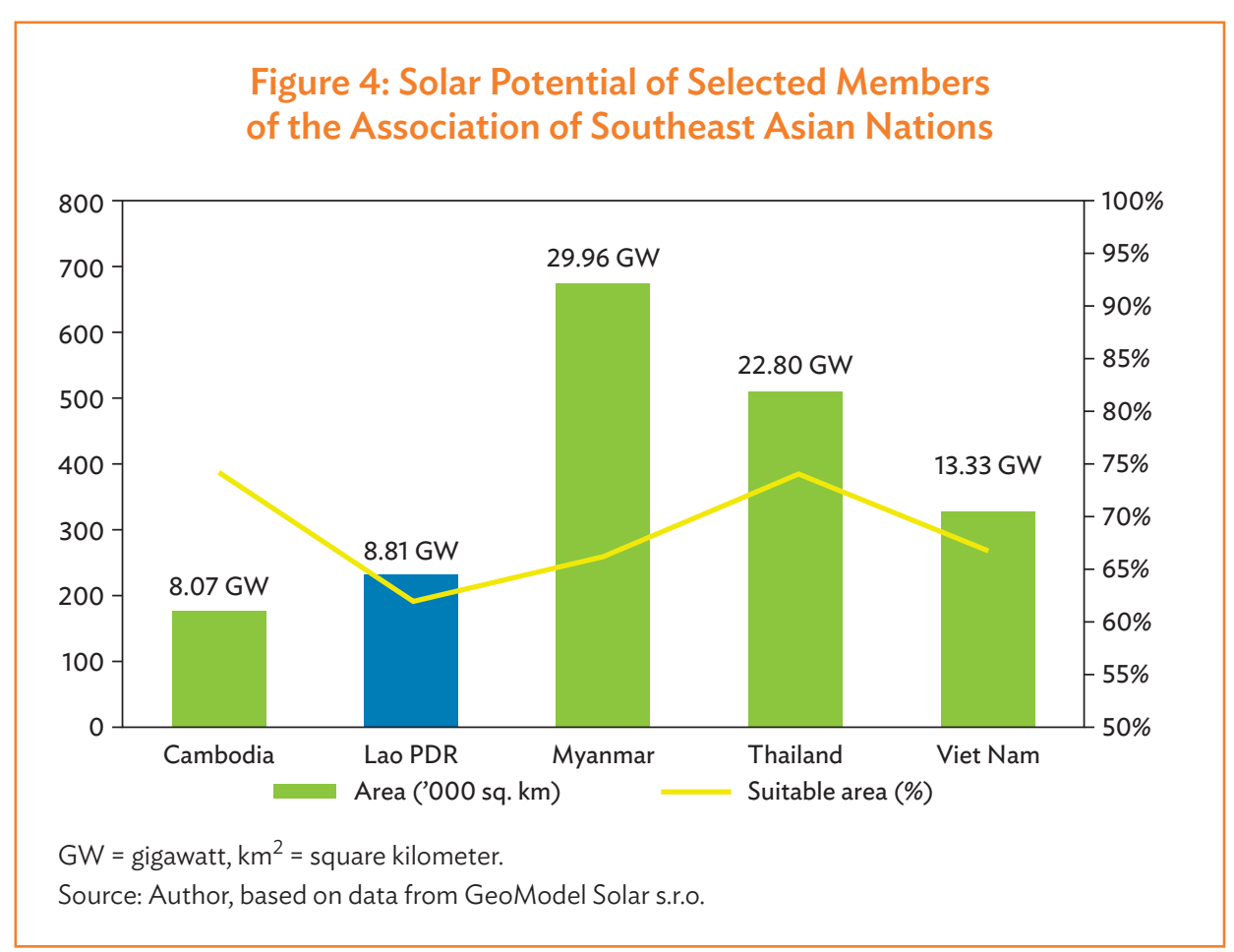

18 In August 2018, the government temporarily suspended new hydropower projects following the collapse of a saddle dam at the Xe Pian-Xe Namnoy Hydropower Project in Attapeu Province the previous month. The Laotian Times. 2018. Lao Government to Suspend All New Hydropower Dam Projects. 8 August. https:// laotiantimes.com/2018/08/08/lao-government-suspend-new-hydropower-dam-projects/.

19 Government of the Lao PDR. 2011. Renewable Energy Development Strategy in Lao PDR. Vientiane.

20 J. Serm. 2007. Assessment of Solar Energy Potentials for Lao People's Democratic Republic. Bangkok: Silpakorn University. 
member countries owing to the Lao PDR's mountainous and forested terrain, and are therefore a limiting factor for the development of utility-scale solar projects (Figure 4). That said, the seasonality in hydropower and solar irradiation occurs at different times of the year, thus providing a degree of complementarity that gives the potential for balancing year-round variations in generation and supply.

Thus far, the development of solar projects has amounted to $32 \mathrm{MW}$, following the commissioning of three government-led pilot projects in Vientiane in February 2017 (3 MW), August 2017 (7 MW), and May 2018 (22 MW). ${ }^{21}$ While a further $68 \mathrm{MW}$ of utility-scale solar photovoltaic (PV) projects are planned by 2020 , scaling of utilityscale solar generation in the Lao PDR will require institutional and financial resources to support grid integration studies, site assessments, and cost-benefit analyses, which are traditionally integral to decisions to make such investments. Rooftop solar PV installations also exist at Wattay International Airport (236 kilowatt-peak [kWp]), EDL's head office (178 kWp), the United Nations Development Programme office (18 kWp), and the Ministry of Industry and Commerce (10 kWp), among other locations (footnote 15).

Given the Lao PDR's geography, there are inherent practical challenges to developing conventional ground-mounted solar in the country; to that end, installing floating solar on reservoirs used for hydropower generation and irrigation dams is being considered by $\mathrm{ADB}$ and other development partners as a potential pathway for more solar power deployment (explored further in section 4.5.1).

Despite the commercial-scale application of solar power being in its infancy, solar power has played an important role in spurring electrification in off-grid areas in the Lao PDR. Around 16,689 solar home systems (SHSs) are in operation across 379 remote villages. The potential for similar distributed technologies to further increase electrification in the country is discussed in section 4.6.22

Wind speeds in the Lao PDR are typically very low at around 1 meter/second, except in some mountainous areas, thus limiting the commercial application of wind power. ${ }^{23}$ While estimates put the country's addressable wind potential at 3,000-3,500 MW, the true potential for the technology is unknown. Indeed, pre-feasibility studies of wind potential have thus far only been undertaken in two districts in Savannakhet Province (64 MW) and one district of Champasak Province (50 MW). ${ }^{24}$ Data collection is underway in Luang Prabang, Xayabuli, Xaisomboun, and Vientiane provinces, as well as Vientiane capital and the remaining districts of Champasak. Currently, there are no operational wind projects in the Lao PDR despite the 73 MW target via the Renewable Energy Development Strategy, 2011-2025,

21 C. Milattanapheng. 2018. Opportunities for Solar Power Projects and a Solar Pilot Auction in Lao PDR. Presentation for the Asia Clean Energy Forum. Manila. 8 June.

22 ADB. 2013. Lao People's Democratic Republic: Energy Sector Assessment, Strategy, and Road Map: 2013 Update. Manila.

23 S. Thoummavongsa. 2017. Renewable Energy Market Development in Lao PDR - Opportunities for investment. Bangkok.

24 ASEAN Centre for Energy. 2017. Renewable Energy Development in Lao PDR. http://usaidcleanpowerasia. aseanenergy.org/resource/renewable-energy-development-in-lao-pdr/. 
though private companies have signed some memorandums of understanding (MOUs) and memorandums of cooperation to date.

The Lao PDR also has significant biomass resources from agricultural and forestry wastes such as rice straw and husks, sawdust, and corn cobs, which are estimated to total 500 million tons of oil equivalent (MTOE) and support up to $938 \mathrm{MW}$ of generation capacity (footnote 14 ). Biomass resources are principally used for energy in households, with more than $80 \%$ of the population relying on biomass energy for applications such as cooking. Biomass fuels are also used in small-scale industrial production in rural areas, such as alcohol production and tobacco processing.

In terms of the use of biomass in electricity generation, two bagasse-fueled plants totaling 39.7 MW of installed capacity are operational in the south of the country, and a $60 \mathrm{MW}$ plant is under construction (footnote 24). Agricultural products and wastes also provide the Lao PDR with a high potential for biofuel production via the utilization of crops such as palm oil, soybean, and jatropha. Among the pilot projects to plant jatropha for biodiesel production is a 2,500-hectare plantation and biodiesel factory in Xayabuli Province that is capable of producing 2,000 liters per day (footnote 11). Biogas production is estimated to be able to support more than $313 \mathrm{MW}$ of generation capacity. ${ }^{25}$

\subsection{Energy Balance}

The total primary energy supply in the Lao PDR was around 2.88 MTOE as of 2016, representing a CAGR of $1.3 \%$ since $2000 .{ }^{26}$ Biomass accounted for nearly half of energy supplied (1.37 MTOE, 48\%), followed by coal (0.40 MTOE, 14\%), electricity generation (0.56 MTOE, 19\%), imported petroleum products (0.49 MTOE, 17\%), and electricity imports (0.07 MTOE, 2\%) (Figure 5). Production from hydropower increased at a CAGR of 8.5\% during 2012-2016; the Lao PDR has since pivoted and is now a net exporter of energy, predomi nantly supplying to Thailand and Viet Nam, and to a lesser extent to Cambodia and Myanmar. ${ }^{27}$

In 2016, total energy consumption stood at 2.46 MTOE, representing a CAGR of $2.4 \%$ since 2000 (footnote 26 ). Total energy consumption comprised $50.8 \%$ in biomass, $18.1 \%$ in petroleum products, $16.5 \%$ in electricity, and $14.6 \%$ in coal. At a sectoral level, residential consumers accounted for the largest share (74\%) of total energy consumption, followed by the transport sector (19\%) and industry (7\%) (footnote 26).

Government of the Lao PDR, Ministry of Energy and Mines. 2017. Renewable Energy Development. Vientiane. Enerdata. Energy Research \& Data. https://www.enerdata.net/research/ (accessed 30 August 2018).

The largest of these hydropower plants is Nam Theun 2, which exports power to Thailand. 
Figure 5: Historical Total Energy Supply by Source and Final Energy Use by Sector in the Lao People's Democratic Republic, 2012-2016

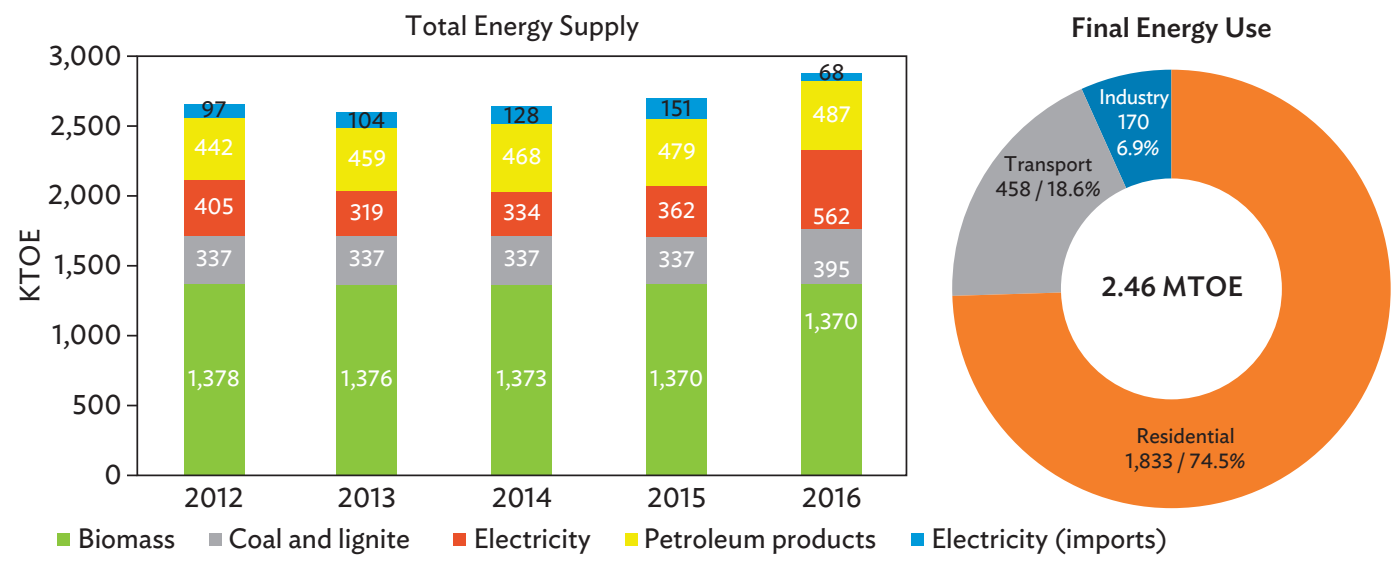

$\mathrm{KTOE}=$ kilotons of oil equivalent, $\mathrm{MTOE}=$ million tons of oil equivalent.

Source: Adapted from Enerdata. Energy Research \& Data. https://www.enerdata.net/research/ (accessed 2 March 2018). 


\section{Institutional Context}

\subsection{Government Institutions in the Power Sector}

Within the government, the Ministry of Energy and Mines (MEM) is primarily responsible for the power sector in the Lao PDR, with jurisdiction over energy policy, strategy, and management of the energy and the mining industries across the country. MEM oversees the activities of several state-owned enterprises (SOEs) involved in the energy sector: EDL, EDL-Generation Public Company (EDL-Gen), and its subsidiary EDL-Gen Solar (the roles of these SOEs are detailed in section 3.2). The Ministry of Finance supports the role of MEM by ensuring financial management and accountability within the energy sector, while also being in charge of strategy and investments of the aforementioned SOEs as well as Lao Holding State Enterprise (LHSE). ${ }^{28}$ The Ministry of Planning and Investment and Ministry of Natural Resources and Environment also provide additional oversight to MEM. Figure 6 illustrates the structure of the Lao PDR's power industry.

MEM underwent restructuring in September 2017 and currently consists of eight departments involved in policy and regulatory affairs. ${ }^{29}$ The departments include the Department of Energy Business (DEB), which is in charge of private sector investments, project development, and project monitoring within the Lao PDR's power sector. More specifically, the responsibilities of DEB include

- reviewing investment proposals, processing technical feasibility studies, and, ultimately, approving generation projects over $15 \mathrm{MW}$;

- $\quad$ performing financial analysis on project feasibility to establish levies, taxes, returnon-investment, and debt arrangements for commercial lenders; and

- implementing project agreements, and monitoring and enforcing compliance under relevant legislation. ${ }^{30}$

Agence Française de Developpement. 2017. Aide-Memoire: Lao PDR Energy Sector Prospection Mission.

29 According to the Lao PDR Agreement No. 296 to Restructure the Ministry of Energy and Mines of 4 September 2017, three new departments were formed within MEM: Department of Planning and Cooperation, Department of Law, and Lao Research Institute for Energy and Mines.

30 Tokyo Electric Power Company Holdings, Inc. and Hokuriku Electric Power Company, Inc. 2017. Study on Economic Partnership Projects in Developing Countries in FY2016: Study on Independent Power Producers (IPPs) in Lao People's Democratic Republic. http://www.meti.go.jp/meti_lib/report/H28FY/000040.pdf. 
Figure 6: Structure of the Power Sector in the Lao People's Democratic Republic

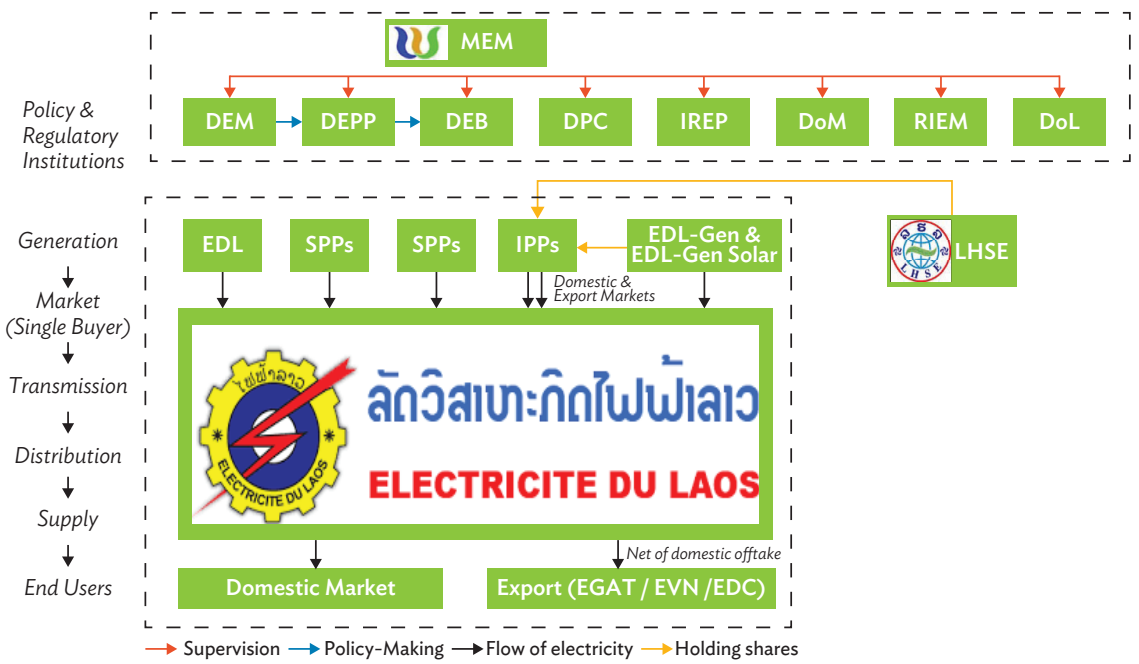

$D E B=$ Department of Energy Business, $D E M=$ Department of Energy Management, $D E P P=$ Department of Energy Policy and Planning, $\mathrm{DOL}=$ Department of Laws, $\mathrm{DOM}=$ Department of Mining Management, $\mathrm{DPC}=$ Department of Planning and Cooperation, $\mathrm{EDC}=$ Électricité du Cambodge, $\mathrm{EDL}=$ Électricité du Laos, EDL-Gen $=\mathrm{EDL}-$ Generation Public Company, EGAT = Electricity Generating Authority of Thailand, EVN = Vietnam Electricity, IPP = independent power producer, IREP = Institute of Renewable Energy Promotion, LHSE = Lao Holding State Enterprise, MEM = Ministry of Energy and Mines, RIEM = Research Institute for Energy and Mines, SPP = small power producer.

Source: Author.

Other departments within MEM include the Department of Energy Policy and Planning, which is responsible for formulating national energy policies and plans; implementing pricing policies for all types of supply; and supporting the DEB with environmental engineering, promotion, and review of hydropower projects at the MOU stage. The Department of Energy Management is in charge of drafting energyrelated laws, regulations, guidelines, and technical and safety standards, and monitors government agencies, SOEs, and private operators for compliance. The Department of Planning and Cooperation is responsible for coordinating various stakeholders such as central and local government agencies, private parties, nongovernment organizations, and foreign governments to engage in cooperation agreements and MOUs. The Institute of Renewable Energy Promotion is responsible for promoting renewable energy, energy conservation, and rural electrification. The Department of Mining Management oversees the administration and promotion of mining, mineral processing, and export and import of mineral products.

Due to the recent restructuring, EDL now assumes responsibility for the negotiation and preparation of documents for concession agreements (mandatory for IPPs to develop, own, and operate generation assets), as well as power purchase agreements (PPAs) and credit facilities (formerly under the mandate of DEB). 
Outside of central government, provincial authorities support rural electrification through the operation of 85 mini-grids supplied by diesel generators, small hydropower, or other renewable sources, and assist with the preparation of regional power development plans (PDPs). Whereas MEM has the authority to approve generation projects of over $15 \mathrm{MW}$, provincial authorities are required to approve projects between $1 \mathrm{MW}$ and $15 \mathrm{MW}$ (footnote 30 ).

\subsection{State-Owned Enterprises}

Within the power sector in the Lao PDR, EDL and LHSE are the two dominant SOEs. Established in 1959, EDL is a state-owned, vertically-integrated electricity utility overseen by MEM and has been responsible for generation, transmission, distribution, and services to all grid-connected customers in the country since $1986 .{ }^{31}$ EDL led the development of the Lao PDR's first hydropower projects and, through its implementation of the national electrification program, has arguably played a central role in supporting socioeconomic development. Electrification levels increased from $36 \%$ in 2000 to $92 \%$ in 2016, and, for much of the population, access to electricity is one of the few tangible ways through which they interface with the state. ${ }^{32}$

From a commercial standpoint, EDL is the single buyer in the domestic power market. EDL also holds shares in four export-oriented hydropower plants that are in operation and several other independent power projects under construction (footnote 11). EDL-Gen, a public company owned by EDL, assumed ownership of nearly all EDL generation assets following its formation in 2010, and, together with EDL, both entities accounted for $813 \mathrm{MW}$ of installed capacity and 2,849 gigawatt-hours (GWh) of generation in $2017 .^{33}$

While the majority of investments in generation are undertaken by EDL, owing to its ability to secure debt financing at more attractive levels, ownership of generation assets is transferred to EDL-Gen following the commissioning of new power projects. However, in light of the high level of indebtedness of EDL, the government is currently considering the full unbundling of EDL into separate companies that would cover its generation, transmission, distribution, and operations and maintenance responsibilities and activities.

EDL-Gen, which is responsible for EDL's generation activities, was established in December 2010 and is $75 \%$ owned by EDL and $25 \%$ by private investors ${ }^{34}$ as listed on the Lao Securities Exchange. EDL-Gen operates by purchasing shares of existing and near-operational generation assets, including those of EDL, financed through the

31 After the EDL Decree of 1986, EDL took on a national role, following on from a power sector that had previously been comprised of provincial public utility companies under the leadership of EDL Vientiane.

32 N. Barma and S. Oksen. 2014. Lao PDR Case Study: Électricité du Laos. In N. Barma, E. Huybens, and L. Viñuela, eds. Institutions Taking Root: Building State Capacity in Challenging Contexts. Washington, DC: World Bank. pp. 119-150.

33 Footnote 15. Figures reflect wholly-owned EDL-Gen assets and not stakes held in IPP projects.

34 Private shareholders include RATCH-Lao Services Company Limited, RH International (Singapore) Corporation Pte. Ltd., and Banque Pour Le Commerce Exterieur Lao Public. 
issuance of bonds and with loans, which collectively amounted to $\$ 1.08$ billion as of mid-2017. ${ }^{35}$ As such, EDL-Gen is the main generator that serves the domestic market in the Lao PDR, and as of 2017 accounted for installed capacity of $622 \mathrm{MW}$ across 10 wholly owned projects, with generation of 2,610 GWh. ${ }^{36}$ In addition, EDL-Gen owns equity stakes in several operational IPP hydropower projects (totaling 2,300 MW) that amount to $635 \mathrm{MW}$ on an ownership-weighted basis (footnote 35). EDL-Gen is

Table 1: Summary of Lao Holding State Enterprise Project Investments, as of December 2017

\begin{tabular}{|c|c|c|c|c|c|c|}
\hline Projects & $\begin{array}{l}\text { Shareholding } \\
\text { Structure }\end{array}$ & $\begin{array}{l}\text { Capacity } \\
\text { (MW) }\end{array}$ & $\begin{array}{l}\text { Project Cost } \\
\text { (\$ million) }\end{array}$ & $\begin{array}{c}\text { Debt/Equity } \\
\text { Ratio }\end{array}$ & $\begin{array}{l}\text { LHSE Equity } \\
\text { (\$ million) }\end{array}$ & $\begin{array}{l}\text { LHSE (Funding } \\
\text { Sources) }\end{array}$ \\
\hline Nam Theun 2 & $\begin{array}{l}\text { EDF (France) } \\
40 \% \\
\text { EGCO } 35 \% \\
\text { LHSE } 25 \%\end{array}$ & 1,080 & 1,297 & $72 / 28$ & $\begin{array}{c}112.5 \\
\text { (real drawdown } \\
\text { 93.4) }\end{array}$ & $\begin{array}{l}\text { ADB, AFD, } \\
\text { IDA, EIB, GOL }\end{array}$ \\
\hline $\begin{array}{l}\text { Hongsa Mine } \\
\text { Mouth Power }\end{array}$ & $\begin{array}{l}\text { Power Plant: } \\
\text { BANPU 40\% } \\
\text { RATCH 40\% } \\
\text { LHSE 20\% } \\
\text { Mining: } \\
\text { BANPU 38\% } \\
\text { RATCH 38\% } \\
\text { LHSE 25\% }\end{array}$ & 1,878 & 3,710 & $75 / 25$ & 217.8 & $\begin{array}{l}\text { Krung } \\
\text { Thai Bank, } \\
\text { Government } \\
\text { Savings Bank }\end{array}$ \\
\hline $\begin{array}{l}\text { Xe Pian-Xe } \\
\text { Namnoy }\end{array}$ & $\begin{array}{l}\text { SK Group } \\
\text { (Republic of } \\
\text { Korea) 26\% } \\
\text { Korea Western } \\
\text { Power 25\% } \\
\text { RATCH 25\% } \\
\text { LHSE 24\% }\end{array}$ & 410 & 1,020 & $70 / 30$ & 100.6 & $\begin{array}{l}\text { Krung } \\
\text { Thai Bank, } \\
\text { Economic } \\
\text { Development } \\
\text { Cooperation } \\
\text { Fund }\end{array}$ \\
\hline \multirow[t]{2}{*}{ Nam Ngiep 1} & $\begin{array}{l}\text { KPIC } \\
\text { Netherlands } \\
\text { B.V. (Japan) } \\
45 \% \\
\text { EGAT } \\
\text { International } \\
30 \% \\
\text { LHSE 25\% }\end{array}$ & 290 & 906 & $71 / 29$ & 103.5 & $\begin{array}{l}\text { JBIC, Thai } \\
\text { EXIM Bank, } \\
\text { Bangkok Bank }\end{array}$ \\
\hline & & 3,658 & 6,933 & $73 / 27$ & 534.4 & \\
\hline
\end{tabular}

Note: Numbers may not sum precisely due to rounding.

$\mathrm{ADB}=$ Asian Development Bank, AFD = Agence Française de Développement, BANPU = Banpu Public Company Limited, EDF = Électricité de France, EGAT = Electricity Generating Authority of Thailand, EGCO = Electricity Generating Public Company Limited, EIB = European Investment Bank, GOL = Government of the Lao PDR, IDA = International Development Association, JBIC = Japan Bank for International Cooperation, LHSE = Lao Holding State Enterprise, MW = megawatt, RATCH = Ratchaburi Electricity Generating Holding Public Company Limited, Thai EXIM = Export-Import Bank of Thailand.

Source: LHSE. Project Investment. http://www.laoholding.com/Investment.aspx (accessed 27 February 2019).

35 World Bank. 2017. Lao PDR Economic Monitor: Lowering Risks and Reviving Growth. Washington, DC.

36 Footnote 15. EDL-Gen accounted for 623 MW of generation capacity in 2017, as indicated in JICA. 2018.

The Study on Power System Network Master Plan in Lao PDR. Presentation prepared for the Preliminary Meeting

for Power Export Scenario Setting. Vientiane. April. 
also actively developing non-hydro renewable energy projects through its subsidiary EDL-Gen Solar.

EDL-Gen Solar is a small subsidiary of EDL-Gen and a relatively new entity, having been established in 2015 to focus on developing solar energy projects in the country. EDL-Gen Solar is majority owned by EDL-Gen, with the Thai firm Pattana Energy Absolute Company Limited holding the remaining 40\% stake (footnote 28). In August 2017, EDL-Gen Solar commissioned two solar pilot projects totaling $10 \mathrm{MW}$ in Vientiane region, with a PPA having been signed with EDL in the following month. These first projects were financed by EDL-Gen (80\%) with EDL-Gen Solar equity comprising the remaining $20 \%$. An additional $22 \mathrm{MW}$ of solar capacity reached commercial operation in May 2018. The price of the electricity sold to EDL is around $\$ 0.08$ per kWh. EDL-Gen Solar has longer-term ambitions to develop an additional $100 \mathrm{MW}$ of solar projects in the Lao PDR for domestic consumption and $500 \mathrm{MW}$ at a later stage to provide exports to Thailand (footnote 28).

While EDL and its subsidiaries manage predominantly state-owned generation assets, LHSE is responsible for the state's financial holdings in hydropower projects built by foreign and private investors. These projects are focused more on cross-border power exports than on serving the domestic market, and include the government's 25\% share in Nam Theun 2 Power Company and a 20\% share in the Hongsa lignite mine mouth power project, among others (footnote 30). LHSE may also hold shares in other generation projects and transmission projects. Table 1 provides a summary of LHSE's current project investments.

\subsection{Role of the Private Sector}

Foreign and private sector investors play a major role-in addition to the role of the Lao PDR's SOEs - in the development of the Lao PDR's generation, transmission, and distribution infrastructure. The country has been very successful in encouraging and attracting private investment and foreign direct investment (FDI) in power generation projects, and, as of the end of 2017, IPPs accounted for around 6.3 gigawatts (GW) (88\%) of total installed capacity in the country. ${ }^{37}$ The country also has a reasonably well-established framework for the participation of IPPs, which continue to play an essential role in the development of the power sector.

All IPPs must enter into concession agreements with the Lao PDR government, with the primary models being the build-operate-transfer (BOT) and buildown-operate-transfer for export-oriented IPP projects, typically with a term of 20-30 years..$^{38}$ Conversely, IPP projects supplying the domestic market are based on a build-own-operate model. IPPs seeking to develop power projects in the Lao PDR can submit either solicited or unsolicited proposals to the government via

37 This figure relates to installed capacity where IPPs are listed by MEM as the project owner.

38 Economic Research Institute for ASEAN and East Asia (ERIA). 2017. Electric Power Policy and Market Structure in ASEAN Member States. In E. Yokota and I. Kutani, eds. Study on Electricity Supply and Role of Policy in ASEAN. http://www.eria.org/RPR_FY2015_no.18_Chapter_2.pdf. 
the Ministry of Planning and Investment, who in turn approach MEM to undertake technical feasibility study (e.g., system planning). IPP projects between $5 \mathrm{MW}$ and $100 \mathrm{MW}$ must be approved by the government upon consultation with stakeholders, while projects greater than $100 \mathrm{MW}$ must be approved by the country's National Assembly. ${ }^{39}$

Domestic PPAs between EDL and the private sector are negotiated on a project basis and lack a common framework for aspects such as contract size, tenor, and price (footnote 30). Indeed, while MEM's Regulation on Domestic IPPs Purchasing Price (2016) sets out United States (US) dollars as the settlement currency, the "model PPA" is instead denominated into a mixture of US dollars and kip $(K N)$, the share of which varies over the project PPA lifetime.

Most of EDL's domestic PPAs come with take-and-pay clauses, ${ }^{40}$ where EDL is only responsible for the volume of electricity generated and sold according to predetermined unit cost. EDL pays out predetermined fees regardless of volume generated and sold (per take-or-pay clause) for a few PPAs with higher than $100 \mathrm{MW}$ generation capacity, at least during the loan tenure (footnote 30 ). While for certain investors obtaining a PPA with a take-or-pay clause is a prerequisite for securing external financing, it could hamstring EDL financially should expected demand not materialize (discussed further in section 5.1.2).

Conversely, developers of export-oriented projects first secure a PPA with neighboring incumbents such as the Electricity Generating Authority of Thailand (EGAT). It is, however, understood that the Lao PDR government is seeking to promote EDL as a single buyer for all power contracts (both domestic and export) over the longer term. Such a transition would afford EDL considerable system flexibility by allowing it to supply the required amount of power contracted by its counterparts in Cambodia, Thailand, and Viet Nam from any substation along the border with each country, rather than dedicated 500-kilovolt (kV) and $230 \mathrm{kV}$ transmission lines that traverse across the country at present. Indeed, a single buyer regime would allow for centralized and holistic system planning to take place and ultimately strengthen the Lao PDR's position as an exporting nation. However, this increases the risk of export buyers to the EDL system and EDL itself and may have negative impacts on the ability of project developers to finance such projects.

The country benefits financially from the involvement of IPPs by earning royalties, collecting taxes, and in some cases receiving dividends. Government revenues from hydropower are expected to rise to 1.6\% of GDP by 2021 from 1.0\% in 2013-2014 (footnote 10). In practice, the materiality of these income streams is countered by the many incentives and exemptions provided to IPPs as set out below.

From an early stage, the Lao PDR has recognized the significant need to attract private and foreign investment to drive the development of generation infrastructure

Government of the Lao PDR. 2017. Law on Electricity (Amended) - Unofficial Translation.

40 Take-or-pay contracts commit the buyer to purchase a minimum amount of off-take or else pay a financial penalty, thus helping provide long-term financial security for capital-intensive infrastructure investments. 
and increase cross-border power exports. The Law on the Promotion of Foreign Investment was promulgated in 2004, followed later in 2009 by the Law on Investment Promotion, which set out the provision of the following financial and nonfinancial incentives for investments in generation and transmission assets in the country:

(i) attractive return-on-investment levels;

(ii) no import duty on production machinery, equipment, and raw materials;

(iii) no import duty on chemical materials necessary for biofuels production within 7 years;

(iv) profit tax exemption for a certain period depending on activities, investment areas, and size of investment;

(v) subsidies on product depending on energy type;

(vi) lease period of up to 75 years;

(vii) permission to repatriate income to home or other countries; and

(viii) permission to employ foreign workers, but not more than $10 \%$ of the total company employment (footnote 11).

Amendments made to the Law on Investment Promotion in April 2017 have seen the removal of minimum registered capital requirements for foreign investors, along with changes in investment incentives (profit tax and concession fee exemptions) for certain promoted business sectors and/or within designated economic zones.

In addition to these financial and nonfinancial incentives, financial support in the form of state-backed investments in IPP generation projects is provided to encourage foreign and private investments in the Lao PDR's power sector. Despite changes in the Electricity Law in 2011 that removed the legal requirement for the government to invest in IPP projects, both EDL-Gen and LHSE continue to provide financial support by investing in many IPP projects, most of which are financed through debt (footnote 30). LHSE, whose financial interests in IPP projects are tied to assets that export to neighboring markets, may need to be increasingly selective in taking equity stakes in such projects over the longer term, particularly given the long lead times for developing such projects and correspondingly the long period before which returns are seen. More broadly, the country's legal framework has also been improved to facilitate international financing of projects, and offshore bank accounts are also permitted.

FDI has driven much of the growth in the Lao PDR's generation capacity. When accounting for projects under development, $74.6 \%$ of the total installed capacity will be foreign sponsored by 2030, with the PRC accounting for $28.9 \%$ and Thailand for 23.8\% (Figure 7).

Overseas investment has played a role supporting growth in the country's national transmission and distribution infrastructure, with EDL entering into BOT contracts that were considered to be relatively inexpensive on an upfront basis. However, the short tenor of these contracts, many only 6-7 years, and the high cost of funding have added to the financial strain currently facing EDL, which could have been lessened through longer tenor contracts, which provide sufficient time for 
Figure 7: Energy Generation Capacity by Sponsor Nation

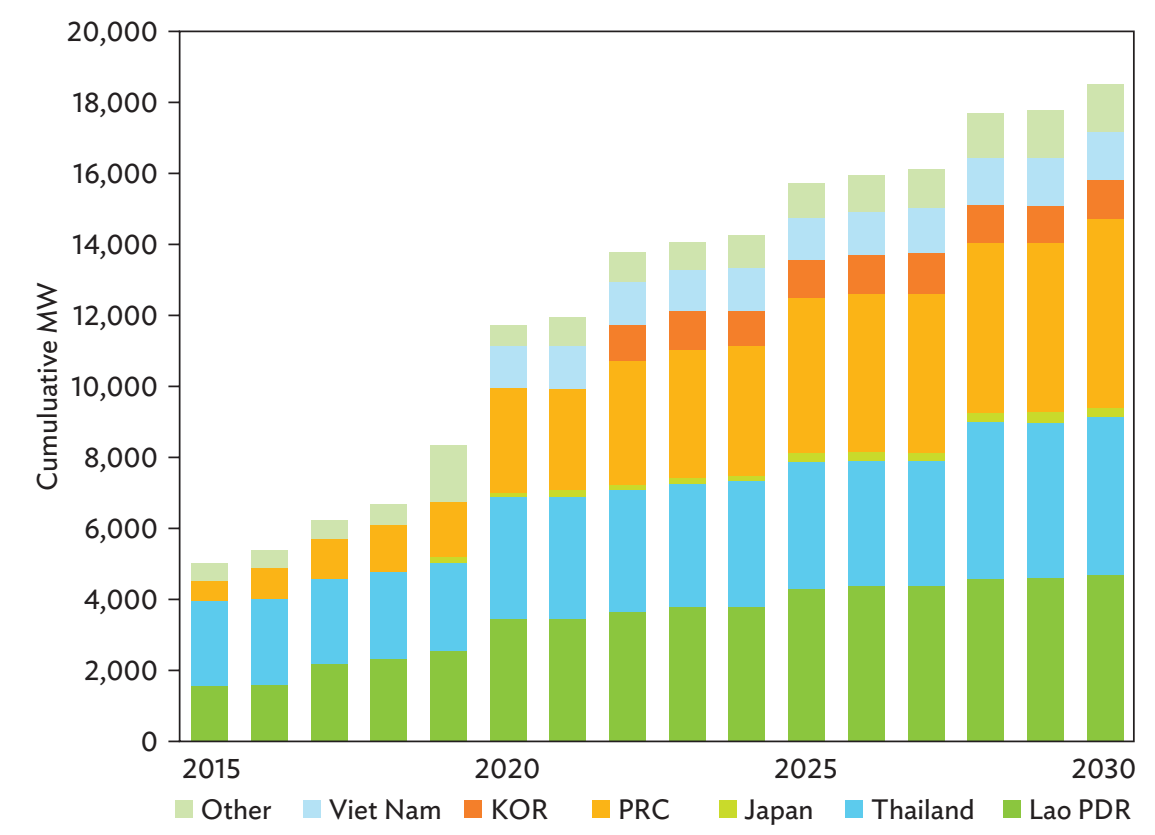

Lao PDR = Lao People's Democratic Republic, MW = megawatt, PRC = People's Republic of China, $\mathrm{KOR}=$ Republic of Korea.

Sources: Tokyo Electric Power Company Holdings, Inc. and Hokuriku Electric Power Company, Inc. 2017. Study on Independent Power Producers (IPPs) in the Lao PDR; Government of the Lao PDR, Ministry of Energy and Mines. 2018. Electricity Statistics 2017. Vientiane; Électricité du Laos. 2016.

Country Presentation. Presentation prepared for the 21st Meeting of the Regional Power Trade

Coordination Committee. Siem Reap. 8-9 December; and Government of the Lao PDR, Ministry of Energy and Mines. 2016. Power Development Plan 2016-2030. Vientiane.

investment costs to be recovered. Additional issues surrounding the quality of national transmission and distribution infrastructure have also been reported and have the potential to exacerbate the financial burden. Going forward, a more thorough and competitive contracting framework is required, along with the transition to more cost-reflective tariffs.

\subsection{Legal Framework}

The Electricity Law of 1997, later revised in 2008, 2011, and 2018, provides the legal framework underpinning the Lao PDR's power sector and establishes the principles, regulations, and measures that govern activities therein. The Electricity Law seeks to promote the sustainable and efficient use of energy resources to support socioeconomic development. At a more actionable level, the Electricity Law requires that electricity development plans be developed at a strategic level and over long-, medium-, and short-term time frames, with the dual objective of promoting cross-border power exports and meeting domestic electricity requirements to drive socioeconomic growth. 
The most recent revision to the Electricity Law, promulgated in August 2018, requires the preparation of a 10-year power development strategy to set out the road map for the power sector. The Electricity Law also stipulates that PDPs be prepared at both the national and provincial levels, and that such PDPs cover 5 years, marking a change from previous PDPs that spanned 10- to 15-year windows. PDPs set out generation and transmission requirements to meet forecasted domestic and export demand and are supplemented by a funding and budgetary plan for the development of new projects (footnote 39). The power development strategy and PDPs must align with the country's socioeconomic development plan, and thus, to the extent possible, keep tariffs low and ensure that water resources, land, and forestry are utilized and managed in an integrated and legally compliant manner.

\subsection{Policy Evolution}

Since its first Power Sector Policy in 1990, the Lao PDR has continued to enact significant policy reforms that guide the development of the power sector. While changing in language and nuance over the years, the country's strategic priorities have followed consistent themes:

(i) promote electricity exports across the ASEAN, particularly to neighboring Thailand and Viet Nam, as a means of generating foreign exchange to finance the Lao PDR's socioeconomic development;

(ii) develop indigenous hydropower resources, with an increasing focus on the participation of private sector foreign investment to build generation infrastructure (footnote 32);

(iii) provide reliable and sustainable electricity supply to the population through affordable tariffs;

(iv) improve electrification, particularly in rural areas (with electrification targets of $70 \%$ by 2010 and $90 \%$ by 2020 both surpassed ahead of schedule); and

(v) encourage both domestic and foreign entities to invest in electricity businesses and activities while promoting cooperation within the sector at regional and international levels.

The National Policy on Sustainable Hydropower Development in Lao PDR, reflecting the central role that hydropower plays in the power sector and its broader economic contribution, was implemented in 2015 . The policy requires project developers and government agencies to undertake due analysis of technical, engineering, financial, environmental, and social considerations on hydro projects larger than $15 \mathrm{MW}$. The environmental implications of the policy are explored further in section 4.5.1.

The government's 8th National Socio-Economic Development Plan (NSEDP) 2016-2020, approved in April 2016, serves as the most recent platform for the implementation of the country's socioeconomic development objectives. ${ }^{41}$ Within the 8th NSEDP, “Vision 2030” targets the Lao PDR's eligibility for graduation from

${ }^{41}$ Government of the Lao PDR, Ministry of Planning and Investment. 2016. 8th Five-Year National SocioEconomic Development Plan (2016-2020). Vientiane. 
least-developed country status by 2020 and ascension to an upper middle-income developing country by 2030. The 8th NSEDP sets out that Vision 2030 requires sustainable economic, social, and environmental development and-recognizing that expanded access to modern and affordable forms of energy and better utilization of current energy resources will play an essential role-prioritizes the need to develop the energy sector in a cost-effective, inclusive, and sustainable manner. The 8th NSEDP is discussed further in section 6.1. Specific objectives that it sets out include

(i) achieving a household electrification ratio of $95 \%$ by 2020 , at reasonable costs;

(ii) utilizing available energy resources by recognizing their competitiveness, sustainability, and efficiency; and

(iii) improving grid connections across the ASEAN through the improvement of transmission infrastructure and harmonization of technical standard. 


\section{Core Sector Issues}

\subsection{Power Capacity and Generation}

\subsubsection{Existing Capacity and Generation}

Installed capacity for domestic supply stood at 2,526 MW as of December 2017 with annual generation of 7.0 terawatt-hours (TWh) as shown in Figure 8. Generation capacity allocated for export was 4,550 MW, with an estimated generation of $24.3 \mathrm{TWh}^{42}$

Aggregate installed generation capacity in the Lao PDR saw a particularly sharp rise between 2014 and 2017, owing largely to the commencement of operations of the three units at the Hongsa mine mouth lignite-fired power plant, a principally exportdriven project. In addition, several hydropower plants serving the domestic market were commissioned (such as Nam Ou 2/5/6, Nam Ngiep 2, and Houay Lamphangnay) and precipitated a state of excess domestic capacity, wherein 2017 year-end capacity was 2,526 MW compared with an annual peak demand of 928.2 MW (footnote 42).

At 1,878 MW, Hongsa represents the country's only large-scale form of thermal baseload generation supply. The majority of the plant's capacity is contracted for export to Thailand, with only $100 \mathrm{MW}$ designated for sale to EDL (footnote 11). As outlined in section 2.1, there are modest lignite reserves of approximately 400 million tons $(\mathrm{mt})$ in Xayabuli Province where Hongsa is situated, while $12.8 \mathrm{mt}$ of the $14.8 \mathrm{mt}$ of lignite mined each year serve the mine mouth plant. Based on the 25-year PPA lifetime and running at a baseload capacity factor, the Hongsa power plant would consume $320 \mathrm{mt}$ of lignite equating to around $80 \%$ of estimated local lignite reserves.

Despite the addition of the lignite-fired plant at Hongsa, the Lao PDR's generation mix is still dominated by hydropower projects, which account for the majority of the country's operational power plants and approximately $73 \%$ of overall generation capacity (Figure 9). Conversely, the large lignite-fired plant in Hongsa accounts for $26 \%$ of capacity, while two plants fueled by sugarcane bagasse account for less than $1 \%$ of capacity.

42 Based on a triangulation of information on past and future, domestic and export capacity and generation from various sources, including Tokyo Electric Power Company Holdings, Inc. and Hokuriku Electric Power Company, Inc 2017. Study on Independent Power Producers (IPPs) in the Lao PDR; Government of the Lao PDR, Ministry of Energy and Mines. 2018. Electricity Statistics 2017. Vientiane; Électricité du Laos. 2016. Country Presentation. Presentation prepared for the 21st Meeting of the Regional Power Trade Coordination Committee. Siem Reap. 8-9 December; and Government of the Lao PDR, Ministry of Energy and Mines. 2016. Power Development Plan 2016-2030. Vientiane. 
Figure 8: Domestic and Export-Oriented Installed Capacity

in the Lao People's Democratic Republic, as of 2017

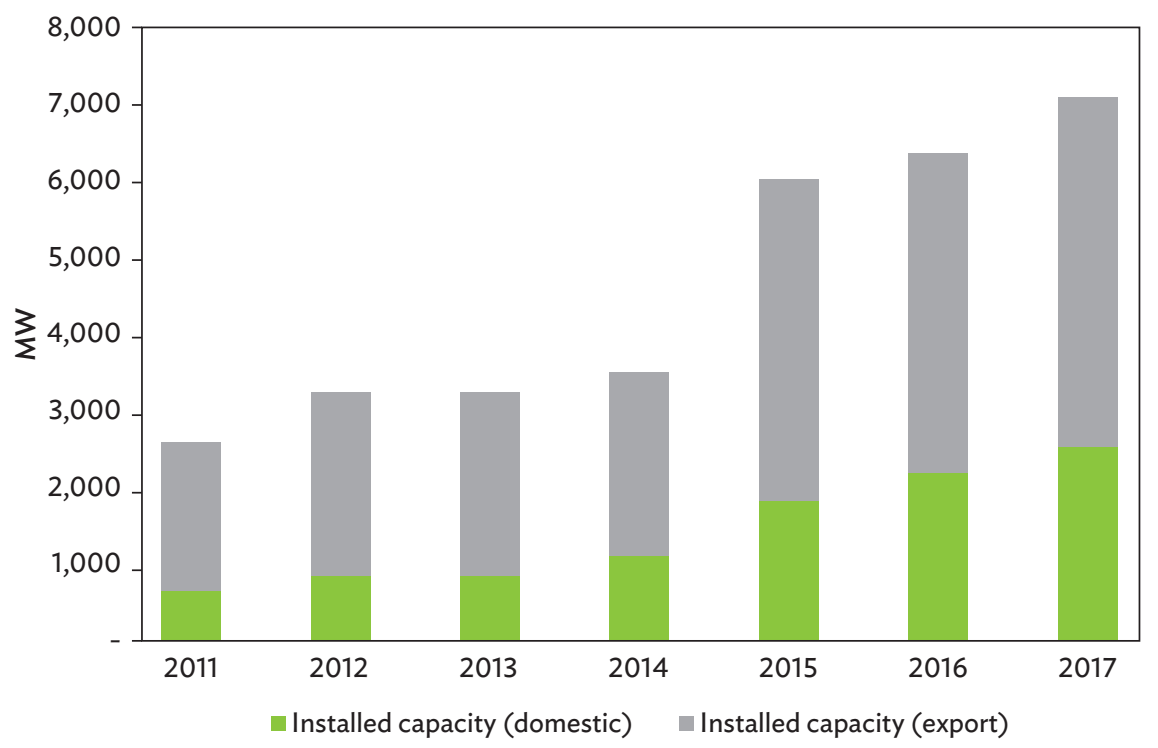

Lao PDR = Lao People's Democratic Republic, MW = megawatt.

Sources: Tokyo Electric Power Company Holdings, Inc. and Hokuriku Electric Power Company, Inc. 2017. Study on Independent Power Producers (IPPs) in the Lao PDR; Government of the Lao PDR, Ministry of Energy and Mines. 2018. Electricity Statistics 2017. Vientiane; Électricité du Laos. 2016. Country Presentation. Presentation prepared for the 21st Meeting of the Regional Power Trade Coordination Committee. Siem Reap. 8-9 December; and Government of the Lao PDR, Ministry of Energy and Mines. 2016. Power Development Plan 2016-2030. Vientiane.

Figure 9: Power Capacity in the Lao People's Democratic Republic, by Domestic Consumption and Export, and by Fuel Source, 2017

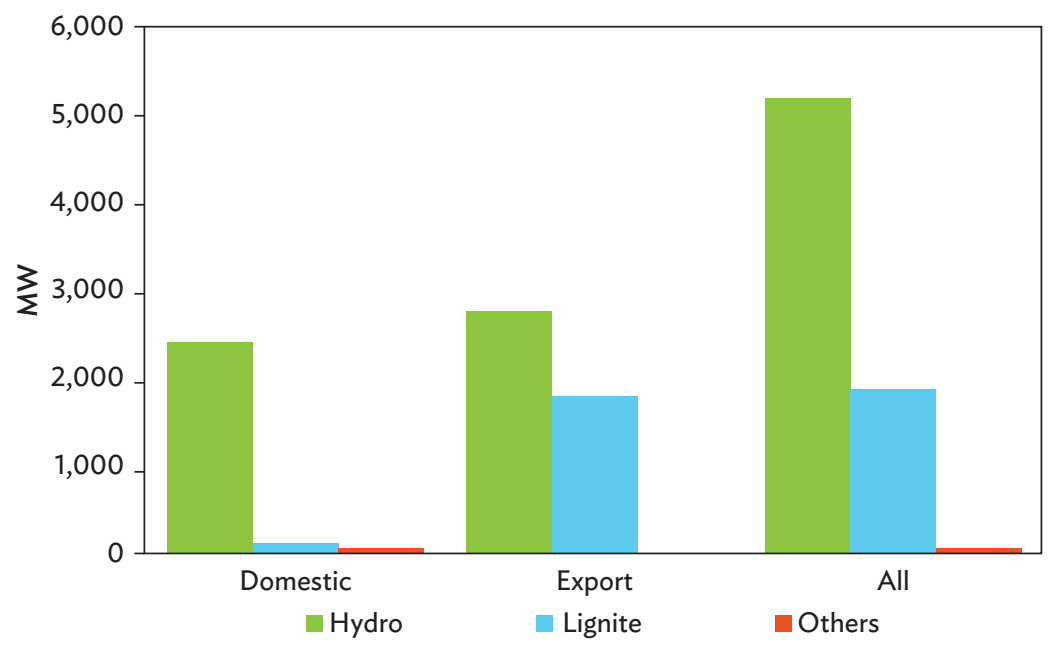

Lao PDR = Lao People's Democratic Republic, MW = megawatt.

Sources: Tokyo Electric Power Company Holdings, Inc. and Hokuriku Electric Power Company, Inc. 2017. Study on Independent Power Producers (IPPs) in the Lao PDR; Government of the Lao PDR, Ministry of Energy and Mines. 2018. Electricity Statistics 2017. Vientiane; Électricité du Laos. 2016. Country Presentation. Presentation prepared for the 21st Meeting of the Regional Power Trade Coordination Committee. Siem Reap. 8-9 December; and Government of the Lao PDR, Ministry of Energy and Mines. 2016. Power Development Plan 2016-2030. Vientiane. 
Figure 10: Past Domestic Generation, Short-Term Exports and Imports

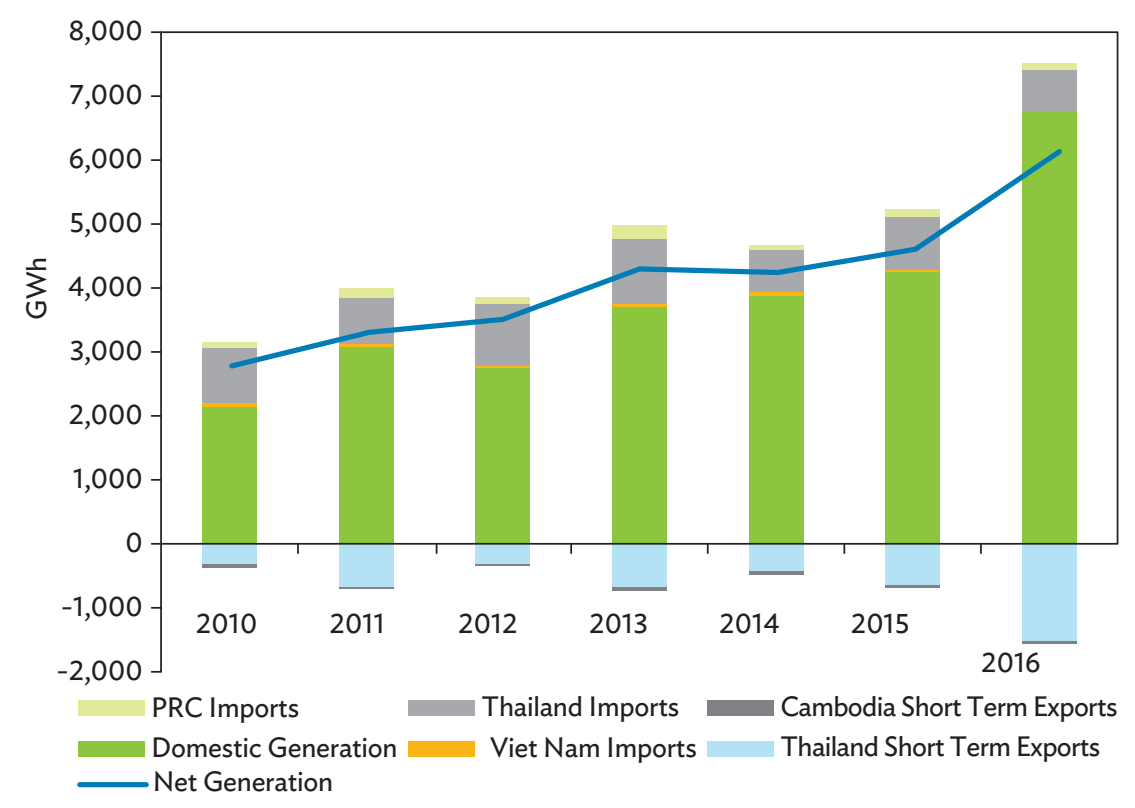

$\mathrm{GWh}=$ gigawatt-hour.

Sources: Tokyo Electric Power Company Holdings, Inc. and Hokuriku Electric Power Company, Inc. 2017. Study on Independent Power Producers (IPPs) in the Lao PDR; Government of the Lao PDR, Ministry of Energy and Mines. 2018. Electricity Statistics 2017. Vientiane; Électricité du Laos. 2016. Country Presentation. Presentation prepared for the 21st Meeting of the Regional Power Trade Coordination Committee. Siem Reap. 8-9 December; and Government of the Lao PDR, Ministry of Energy and Mines. 2016. Power Development Plan 2016-2030. Vientiane; and ADB. 2017. Lao PDR: Accelerating Structural Transformation for Inclusive Growth: Country Diagnostic Study. Manila.

Recent trends in domestic generation, cross-border exports, and short-term imports are summarized in Figure 10. ${ }^{43}$ While additions to domestic capacity have helped propel generation upward and increased short-term exports to Thailand, the Lao PDR has historically relied on imports from Thailand to balance the effects of the dry season, where both high domestic demand and lower dependable hydropower capacity coincide to drive system tightness. At the same time, a lack of transmission capacity has limited the ability to move power from the north to the south. Issues of seasonality, imports, and exports are discussed further in sections 4.2.1 and 4.3.

An analysis of capacity data, commissioning dates, and plant capacity factors indicates that close to 1,350 MW of domestic capacity ${ }^{44}$ was commissioned from 2014 to 2017, which more than doubled the existing national capacity from 1,176 MW to 2,526 MW. ${ }^{45}$ Interestingly, this translated into only a 70\% increase in domestic generation over

43 Data exclude long-term exports of power to Thailand from dedicated plants governed by PPAs.

44 In particular, $100 \mathrm{MW}$ from Hongsa Lignite, $130 \mathrm{MW}$ at Nam Khan 2, $180 \mathrm{MW}$ at Nam Ou 6, and $240 \mathrm{MW}$ at Nam Ou 5.

45 Based on a power generation model that triangulates past and future capacity factors, commissioning dates, and capacity (footnote 42). These historical inputs proved a close match for domestic generation from 2011 to 2016. $267 \mathrm{MW}$ was added in 2017. 
Figure 11: Rainfall Trends in the Lao People's Democratic Republic

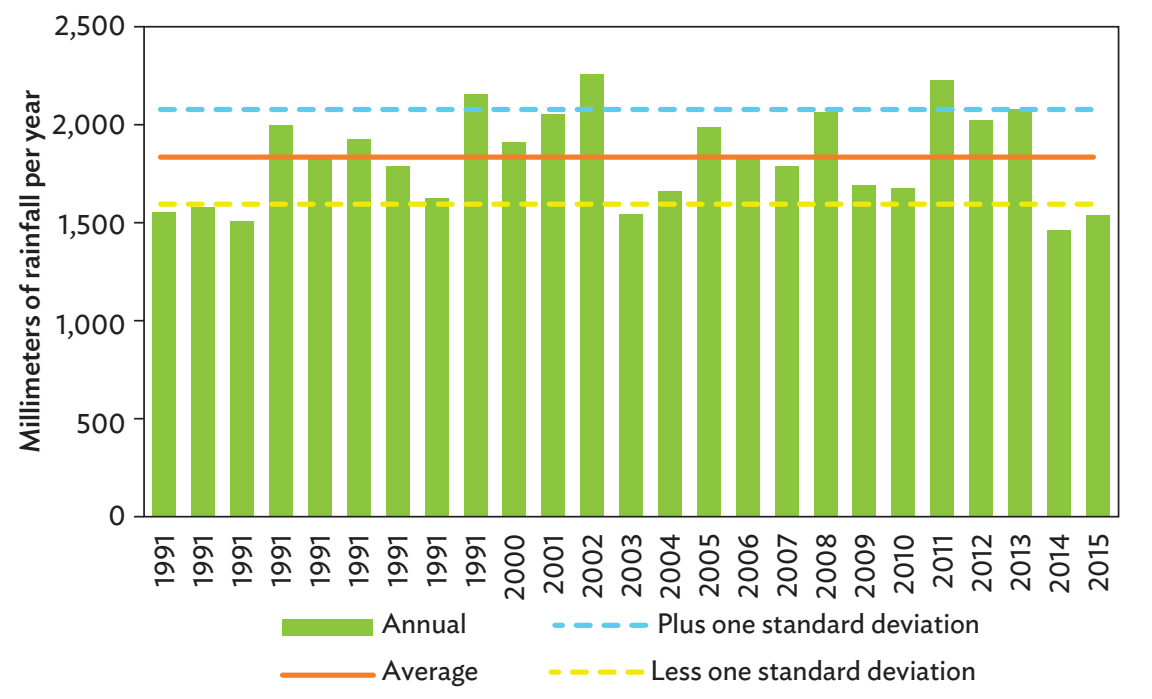

Source: World Bank. Climate Change Knowledge Portal. http://sdwebx.worldbank.org/ (accessed 15 January 2018).

the same period to 7.0 TWh, and thus did not wholly track the increase in capacity for several reasons. First, most of these new hydropower plants were reservoirbacked projects and not run-of-river, therein requiring a few years to fill up before full generation can be achieved. Second, some existing plants are functioning at capacity factors well below design potential. ${ }^{46}$ The average capacity factor of Nam Song (6 MW) is at 17.5\% while that of Nam Ngiep 3A (44 MW) is at 15.1\% between 2015 and 2016. While the precise reasons are unknown for the lag in output, the average rainfall in 2014 and 2015 may also be a contributing factor (Figure 11).

\subsubsection{Forecast Capacity and Generation}

The Lao PDR has abundant hydro resources with an estimated exploitable potential of around $23 \mathrm{GW}$ when the country's share of the Mekong River is taken into account (footnote 28). The country's mountainous and upland topography provide a significant amount of water catchment. Based on an analysis of projects coming online by 2030 , total hydropower build-out for both domestic and export use will total $16.5 \mathrm{GW}$ or around $70 \%$ of estimated potential, with $8.7 \mathrm{GW}$ serving the domestic market and 7.8 GW being export-oriented (footnote 42).

Forthcoming power capacity additions and associated generation forecasts have been informed by an analysis of several documents provided by the Lao PDR authorities and reports from visiting foreign missions.$^{47}$ Analysis indicates that domestically, by 2030 , peak generation demand will have risen to 3,990 MW, equating to a compound annual growth rate (CAGR) of $11 \%$, while generation will increase to 37 TWh, equating to a

46 In particular, Nam Xekaman 3, Nam Lik 1/2, Nam Ngiep 3, Nam Gnuang 3, Se Namnoi 1, and Nam Song.

47 Footnote 42. Government of the Lao PDR, Ministry of Energy and Mines. 2016. Power Development Plan 2016-2030. Vientiane. 
CAGR of 13\%, indicating a slight rise in the system load factor. ${ }^{48}$ This impressive rate of growth is driven, in particular, by ever-increasing levels of electrification outlined in official plans and growth from the industrial sector. Demand by extractive industries is a trend that is likely to continue in light of the build-out of several large and energyintensive mining projects; however, it is worth noting that the mining industry is cyclical and vulnerable to fluctuations in commodity prices. ${ }^{49}$

\section{Generation Capacity Serving the Domestic Market}

The vast bulk of new capacity additions in the Lao PDR will be hydropower, and there are close to 12,000 MW of domestic hydro projects at various stages of development. However, a project-by-project analysis that excludes those projects that have been subject to numerous project development agreement and MOU renewals, have not reached construction agreement stage, and/or cannot attract robust sponsors indicates that around 6,250 MW of hydropower projects are likely to come online between 2018 and 2030 (Figure 12). ${ }^{50}$

Figure 12: Power Capacity for Domestic Consumption and the Adjusted Reserve Margin in the Lao People's Democratic Republic

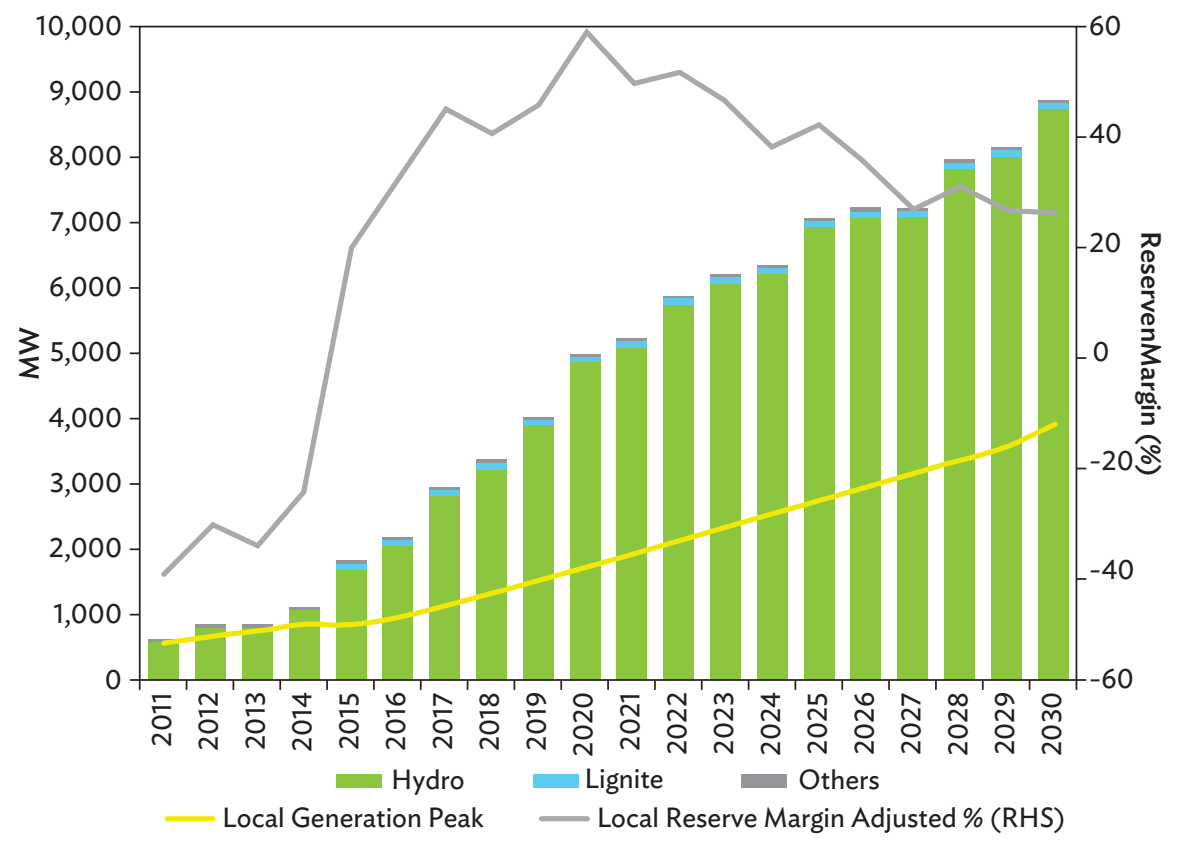

Lao PDR = Lao People's Democratic Republic, MW = megawatt, RHS = right-hand side axis. Sources: Tokyo Electric Power Company Holdings, Inc. and Hokuriku Electric Power Company, Inc. 2017. Study on Independent Power Producers (IPPS) in the Lao PDR; Government of the Lao PDR, Ministry of Energy and Mines. 2018. Electricity Statistics 2017. Vientiane; Électricité du Laos. 2016. Country Presentation. Presentation prepared for the 21st Meeting of the Regional Power Trade Coordination Committee. Siem Reap. 8-9 December; and Government of the Lao PDR, Ministry of Energy and Mines. 2016. Power Development Plan 2016-2030. Vientiane.

48 Sales peak would be 3,600 MW based on transmission and distribution losses of $10 \%$.

49 For example, the mining industry in the Lao PDR is vulnerable to fluctuations in commodity prices, such as those of the Sino-Lao Aluminum Corporation.

50 The balance of 6,250 MW of excluded projects comprises, among others, approximately $2.0 \mathrm{GW}$ at MOU stage, $1 \mathrm{GW}$ at project development agreement stage, and $2.3 \mathrm{GW}$ described as "planned." 
In the immediate future, the addition of 6,250 MW of domestic hydropower plants will shift the domestic power sector to a state of substantial excess capacity, which is reflected in an adjusted wet season reserve margin ${ }^{51}$ that reaches $52.6 \%$ by 2023 , and which is expected to entirely remove the need for imports within the next 2 years even during the dry season. Domestic generation is forecast to rise to 37 TWh by 2030 from 7.0 TWh in 2017, or at a CAGR of 13\% (Figure 13).

On a capacity basis, the hydropower generation in the Lao PDR is largely comprised of reservoirs, but run-of-river hydro is accounting for a substantial portion of new build. By 2030, reservoirs and run of river could each account for half of hydro installed capacity (footnote 42). By 2020, there will be close to $400 \mathrm{MW}$ in hydro capacity accounted for by 50 power plants of less than $15 \mathrm{MW}$, with such plants serving domestic demand rather than the export market. By 2030, a further $400 \mathrm{MW}$ of small-hydro could be added to the fleet by 90 plants if all planned projects are built. That would take the small-hydro capacity to $800 \mathrm{MW}$ out of a total installed capacity of close to $18,000 \mathrm{MW}$ (footnote 42 ).

Figure 13: Outlook for Generation Serving the Domestic Market in the Lao People's Democratic Republic

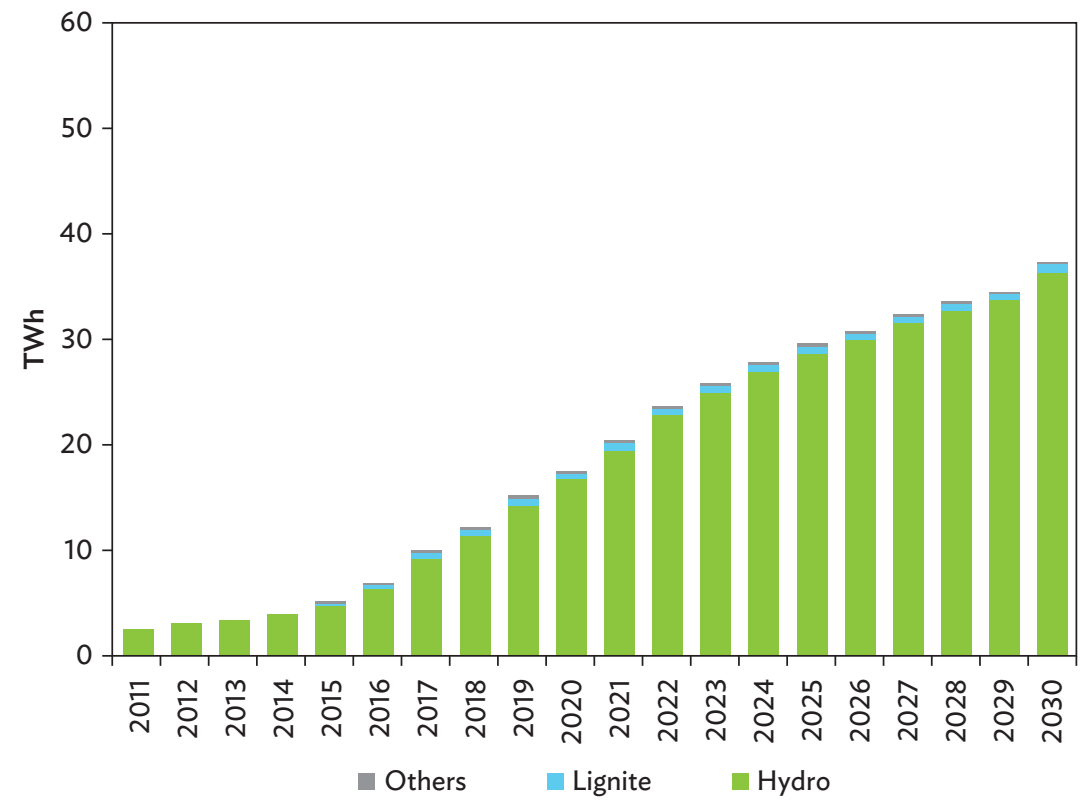

Lao PDR = Lao People's Democratic Republic, TWh = terawatt-hour.

Sources: Tokyo Electric Power Company Holdings, Inc. and Hokuriku Electric Power Company, Inc. 2017. Study on Tokyo Electric Power Company Holdings, Inc. and Hokuriku Electric Power Company, Inc. 2017. Study on Independent Power Producers (IPPs) in the Lao PDR; Government of the Lao PDR, Ministry of Energy and Mines. 2018. Electricity Statistics 2017. Vientiane; Électricité du Laos. 2016. Country Presentation. Presentation prepared for the 21st Meeting of the Regional Power Trade Coordination Committee. Siem Reap. 8-9 December; and Government of the Lao PDR, Ministry of Energy and Mines. 2016. Power Development Plan 2016-2030. Vientiane.

${ }^{51}$ All hydro derated by $50 \%$. The reserve margin stated reflects the end of the dry season (specifically April or May) which is when peak demand typically occurs and when hydro production is low. 
On its present trajectory, the substantial increase in generation capacity and resulting oversupply in the coming years will likely not improve until the late 2020 s, when adjusted reserve margins level off to reach $26.7 \%$ by 2030 . In the near- to mediumterm, this presents a challenge to EDL on several fronts. One of the foremost issues is that it is set to increase the financial burden on EDL because of the liabilities it will face due to most domestic PPAs having take-or-pay clauses. It will also require a significant build-out and strengthening of the transmission and distribution grids in the country, and these costs will invariably need to rise if the country is to find a way to export their surplus power. These issues and constraints are discussed further in sections 4.3 and 4.4 .

While the country's outlook for new build is focused on export-oriented hydropower projects, which in turn form a central part of its economic development strategy, ${ }^{52}$ the ability of the Lao PDR to meet its own domestic needs across all regions will need to be carefully balanced with the desire for greater exports. As an example, the large Nam Thuen 2 hydro plant in the central 2 area provides 1,000 MW of capacity for exports to Thailand with EDL taking just $75 \mathrm{MW}$, yet the demand-supply balance in

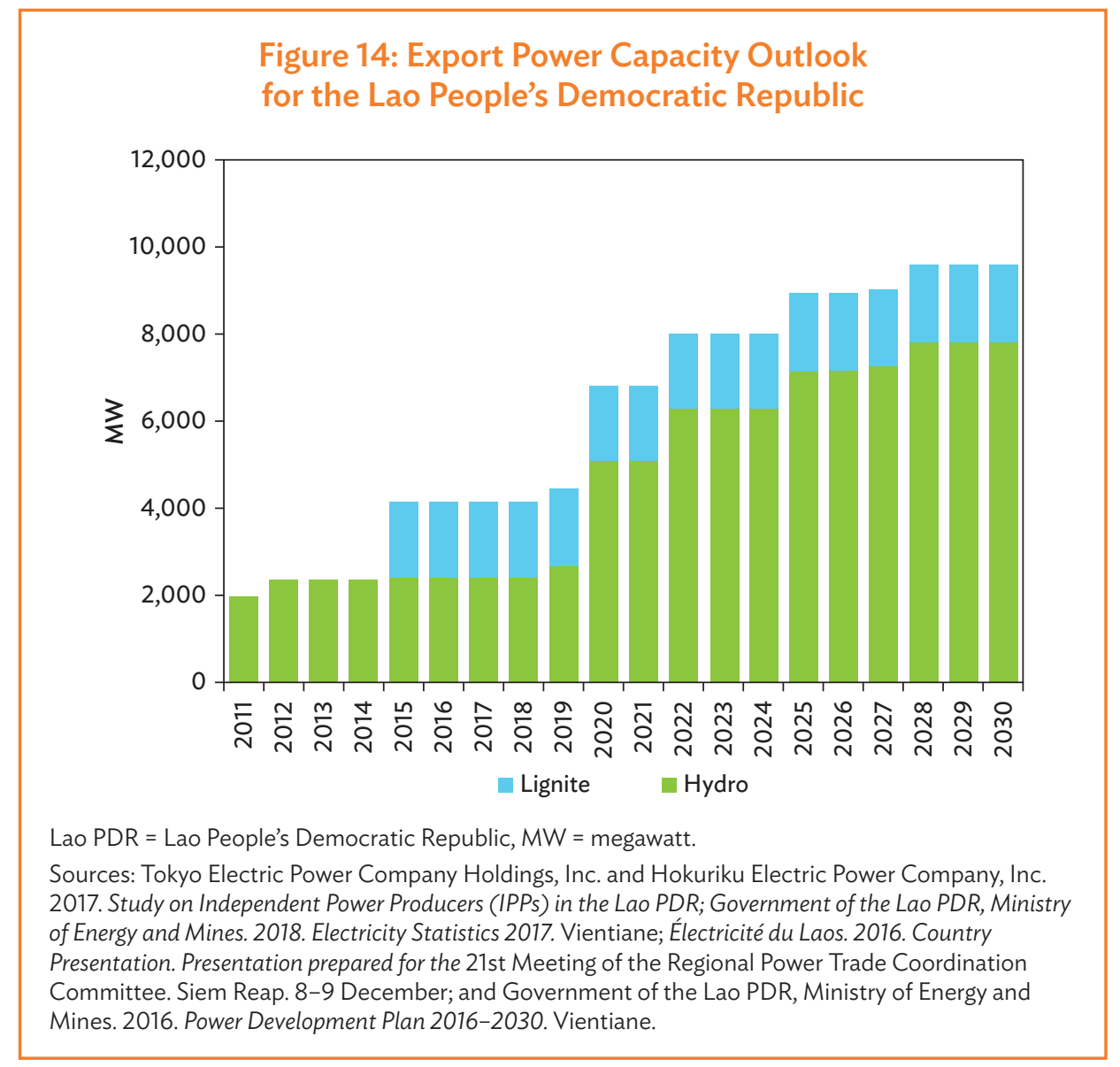

52 Government of the Lao PDR, Ministry of Energy and Mines, Department of Energy Policy and Planning. 2015. Energy Policy August 2015. Vientiane. 
central 2 is tight and in the adjoining southern region is negative. Moreover, exportoriented IPP project capacity is, with a few exceptions, directly connected to the respective transmission network of the off-taker, meaning that such plants are not physically capable of serving the domestic market.

\section{Export-Oriented Generation Capacity}

The trend in export-oriented capacity additions beyond 2017 is similarly dominated by hydropower (Figure 14). The growth profile for export hydro capacity is "lumpy" compared with that for domestic hydro because most export-oriented projects are quite large and much fewer than smaller domestically oriented projects. There are no additions of lignite for export as the four proposed lignite power plants are marked for domestic use. If the Lao PDR were to build grid solar, it would be most likely to support rural distributed residential demand and not exported.

Contracted power exports are forecast to rise to 50 TWh by 2030 from 16 TWh in 2016, or at a CAGR of $9 \%$ (Figure 15). ${ }^{53}$

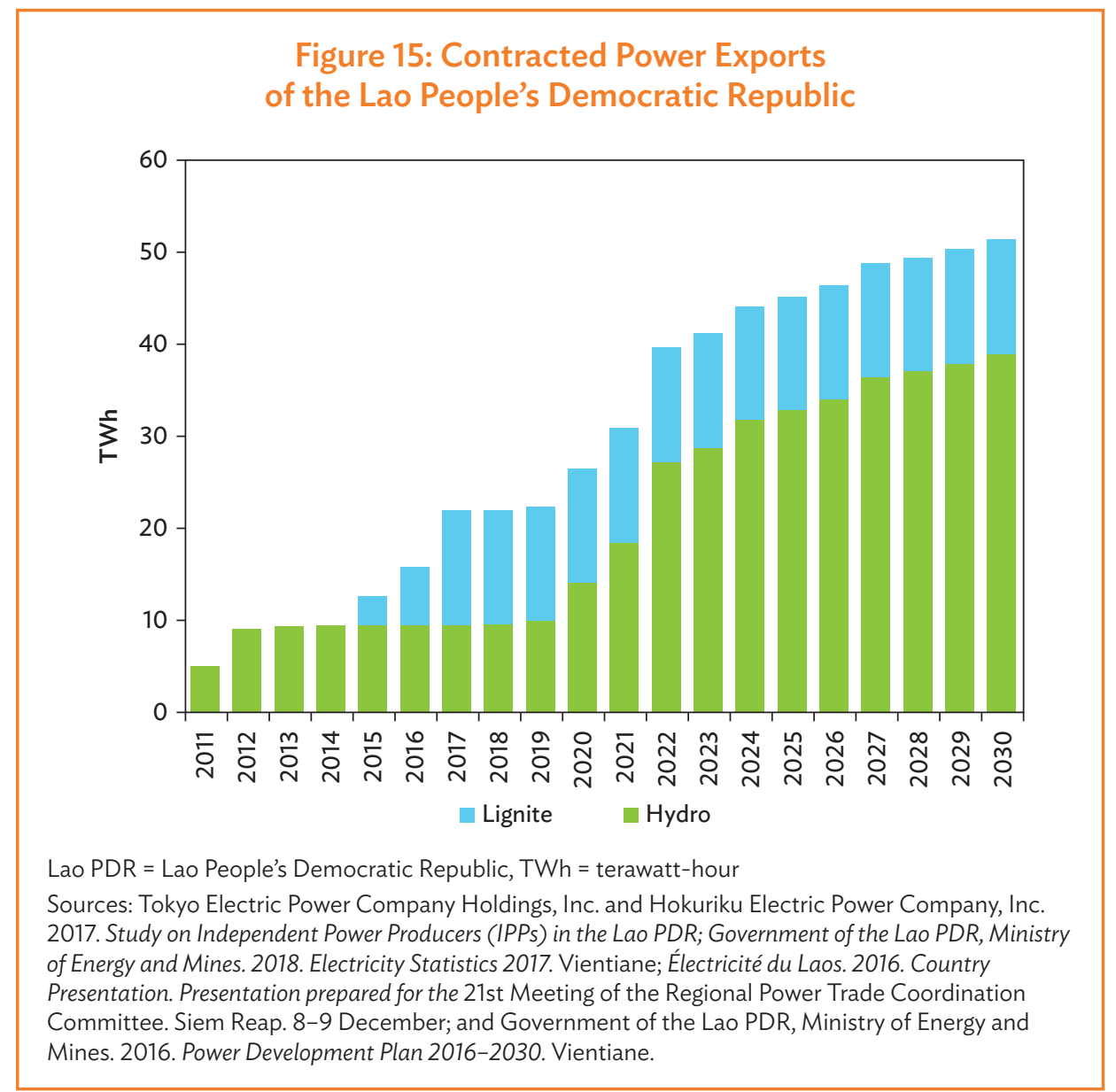

53 This pace of growth is not inconsistent with EGAT's 2015 Power Development Plan, which expects a substantial rise in hydro imports to Thailand through 2036. 


\section{Diversification of the Generation Mix and New Renewable Technologies}

With a view to lowering the seasonality risks associated with the high weighting of hydropower in the generation mix, the authorities in the Lao PDR have indicated a desire to introduce more thermal capacity in the fuel mix (Table 2). This is most likely to be lignite-fired plants, but progress on proposed projects is slow. ${ }^{54}$

Non-hydro renewables, such as solar and wind, would similarly provide a means for the Lao PDR to diversify its generation mix, yet currently lack any visibility in the Lao PDR's long-term PDP. ${ }^{55}$ This is partly a reflection of MEM's unwillingness to subsidize any additional cost of renewable energy and the challenges of deploying renewables in an environment where end-user tariffs are already below cost recovery levels for conventional forms of generation (discussed in section 4.4.1). No feed-in tariffs are planned for domestic sales to EDL, meaning that renewable energies will need to be competitive to allow their rollout (footnote 28 ).

Utility-scale solar is increasingly gaining traction in countries such as Thailand and the Philippines. But the mountainous and forested geography of the Lao PDR also presents practical challenges to increasing capacity. Thus far, $32 \mathrm{MW}$ of pilot solar projects have been completed by May 2018 (footnote 21). With this progress, the Lao PDR is on track to meet its 2020 target of $36 \mathrm{MW}$ stated under the Renewable Energy Development Strategy, 2011-2025 as shown in Table 3.56

As there are practical challenges to developing conventional ground-mounted solar within the country, floating solar has recently become prominent in discussions regarding renewable energy deployment. Floating solar, sited on reservoirs used for hydropower generation and irrigation dams, not only circumvents land constraint issues but also provides essentially "symbiotic" benefits. These benefits include reducing water evaporation from reservoirs, thus improving hydropower capacity factors, and boosting the energy yield from solar PV due to the convection cooling effect of the water. Floating solar can also use existing transmission resources in a

\section{Table 2: Current and Official Proposed Future Plant Type Mix in the Lao People's Democratic Republic}

\begin{tabular}{lcc} 
Plant Type & Present \% of Capacity & $\%$ of the fleet by 2030 \\
\hline Reservoir hydro & 75 & 40 \\
Run-of-river hydro & 20 & 40 \\
Thermal & 5 & 20 \\
Sources: Tokyo Electric Power Company Holdings, Inc. and Hokuriku Electric Power Company, Inc. 2017. \\
Study on Independent Power Producers (IPPs) in the Lao PDR; Government of the Lao PDR, Ministry of Energy \\
and Mines. 2018. Electricity Statistics 2017. Vientiane; Électricité du Laos. 2016. Country Presentation. \\
Presentation prepared for the 21st Meeting of the Regional Power Trade Coordination Committee. Siem \\
Reap. 8-9 December; and Government of the Lao PDR, Ministry of Energy and Mines. 2016. Power \\
Development Plan 2016-2030. Vientiane.
\end{tabular}

54 Four plants summing to 2,700 MW are at the planning or MOU stage: Houa Muang (Lignite), Sam Tai (Lignite), Lamam (Lignite), and M Kalum (Lignite).

55 ADB. 2018. Final Gap Analysis Report. Consultant's Report. Manila (TA 9003-REG).

56 Government of the Lao PDR. 2011. Renewable Energy Development Strategy in Lao PDR. Vientiane. 
Table 3: Renewable Energy Development Targets for the Lao People's Democratic Republic

\begin{tabular}{|lccc|}
\hline Source & $\begin{array}{c}\text { Target 2010-2015 } \\
\text { (cumulative MW) }\end{array}$ & $\begin{array}{c}\text { Target 2016-2020 } \\
\text { (cumulative MW) }\end{array}$ & $\begin{array}{c}\text { Target 2021-2025 } \\
\text { (cumulative MW) }\end{array}$ \\
\hline Small hydro & 80 & 134 & 400 \\
\hline Solar & 22 & 36 & 33 \\
Wind & 6 & 12 & 73 \\
\hline Biomass & 13 & 24 & 58 \\
\hline Biogas & 10 & 19 & 51 \\
\hline Municipal solid waste & 9 & 17 & 36 \\
\hline
\end{tabular}

Lao PDR = Lao People's Democratic Republic, MW = megawatt.

Source: Government of the Lao PDR, Ministry of Energy and Mines, Institute of Renewable Energy Promotion. 2016. Renewable Energy Data in Lao PDR. Paper prepared for the East and Southeast Asia Renewable Energy Statistic Training Workshop. Bangkok. 12-14 December.

symbiotic manner with storage hydro. Perhaps more importantly, the integration of solar power with hydropower would mitigate the effects of hydro resource seasonality and, depending on the relative proportion of solar that could be installed, allow for generation optimization that provides increased dispatchable energy supply akin to more of a baseload operating regime, as opposed to mid-merit or peaking. The fast ramp rates of hydropower generation mean that solar intermittency can also be balanced.

In November 2017, ADB identified the potential for several GW of floating solar within the Lao PDR, of which over $1 \mathrm{GW}$ could conservatively be deployed at the large reservoirs of Nam Ngum 1, Nam Ngum 2, Nakai, and Nam Gnouang. ${ }^{57}$ Among other benefits cited by ADB are the ability for floating solar to be deployed quickly in the country (over 1,000 MW per annum), its modular nature allowing the initial capital outlay to be minimized, and its scalability (it can track underlying demand growth). Integration of floating solar and hydropower generation would also allow existing transmission lines to be utilized or upgraded, thus mitigating the need for greenfield transmission capacity to be developed (footnote 28).

\subsection{Domestic Demand}

Electricity consumption in the Lao PDR stood at 4.97 TWh in 2017, with peak demand reaching $928.2 \mathrm{MW}$ and, after adjusting for losses, an estimated generation peak at $955 \mathrm{MW} .{ }^{58}$ The country has experienced a rapid increase in domestic electricity demand in recent years, experiencing a CAGR of close to $9.5 \%$ during

57 P. Tharakan. 2017. Potential for Floating Solar in Lao PDR: A "quick-look" Assessment. Presentation presented for Developing a Solar Policy Roadmap and Auction Policies for Lao PDR. Vientiane. 17 November.

58 Footnote 15. Assuming transmission and distribution losses of 13.4\%. In 2017, electricity consumption reached 5.38 TWh, according to EDL. 2018. Current Situation and Future Plan of Lao Power Generation, Transmission and Interconnection in GMS Countries. Presentation prepared for the 1st Laos-Myanmar Joint Working Committee Meeting on Power Cooperation. Nay Pyi Taw. 25 May. 
2007-2017 (footnote 15). Over the same period, electricity consumption per capita rose from $218 \mathrm{kWh}$ to $725 \mathrm{kWh}$ per capita but remains one of the lowest in Southeast Asia (footnotes 9 and 15).

Increases in demand have occurred in tandem with strong economic growth, and, at a sectoral level, have been spurred by the residential sector and improved levels of electrification, with growth transitioning in recent years to the industrial sector. Indeed, the industrial sector is now the most significant driver of demand growth, having risen almost threefold during 2010-2017 at a CAGR of 16.7\%, and at 2.09 TWh, accounted for $42 \%$ of total consumption in 2017. In the residential sector, demand rose by a CAGR of 9.8\% during 2010-2017 to 1.81 TWh and accounts for $37 \%$ of total consumption. Growth in the commercial sector has been more modest, however, rising by a CAGR of $3.8 \%$ and at $0.76 \mathrm{GWh}$, accounted for $15.3 \%$ of total consumption (Figure 16).

At a more granular level, peak demand typically occurs between April and May each year, coinciding with seasonally higher temperatures that drive domestic and commercial loads higher. Figure 17 shows the diurnal composition of the country's electricity demand, in this case during the peak day of 2016. Central 1 region, which includes Vientiane, accounts for around $53 \%$ of daily peak demand and also a significant proportion of the "diurnal flex" that sees peak demand occur in the evening.

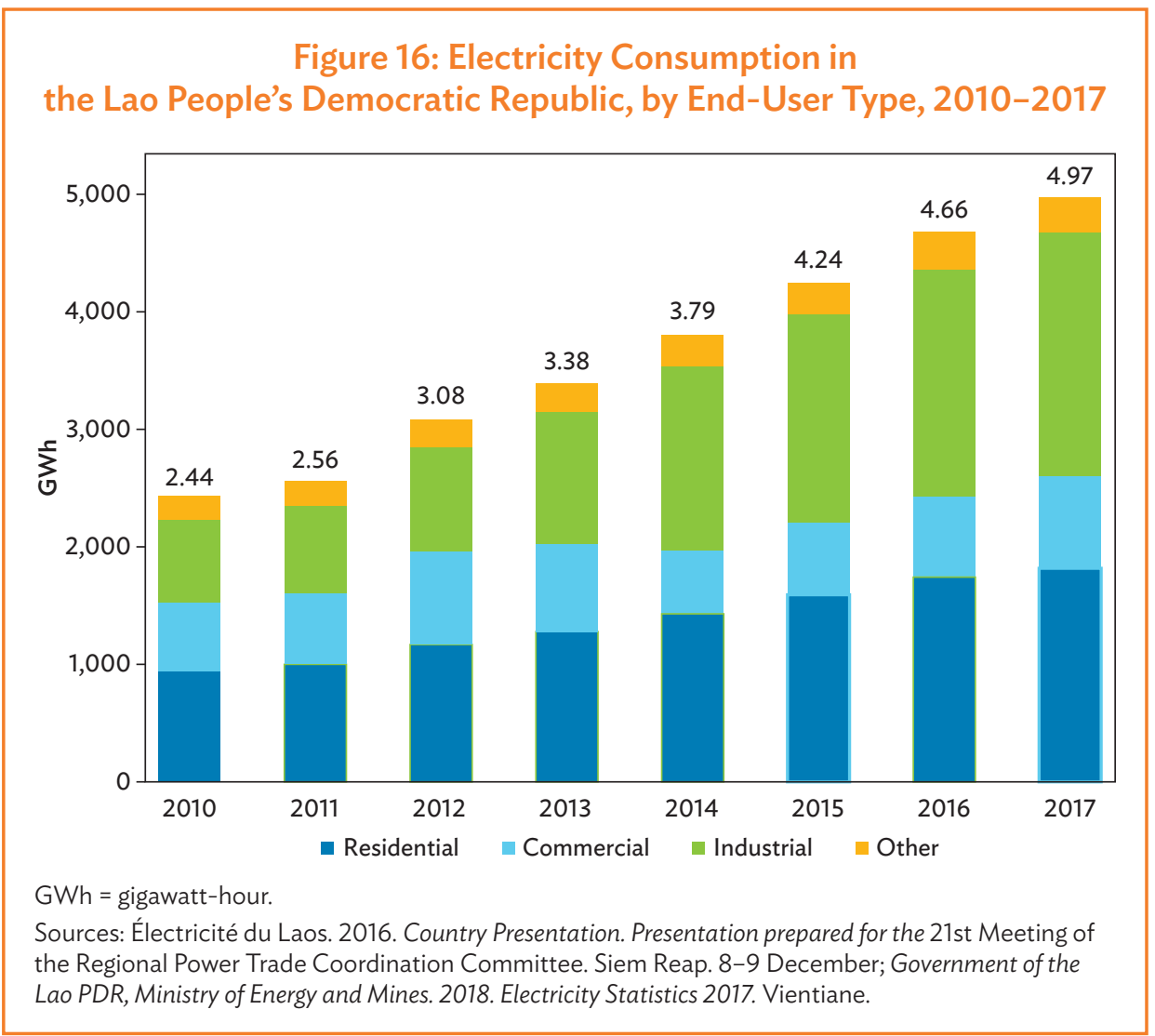




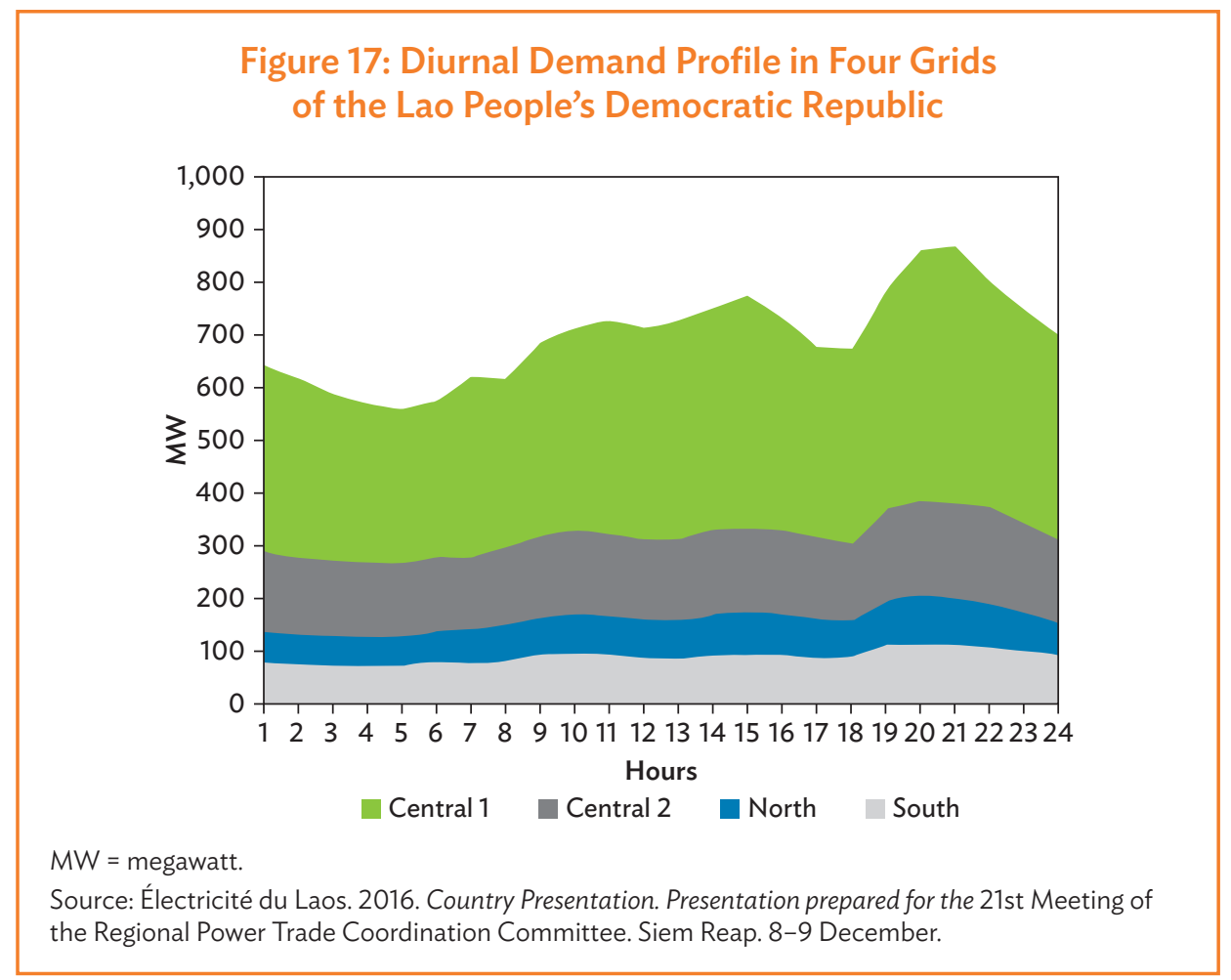

\subsubsection{Seasonality and Imports}

The impressive demand growth in the Lao PDR, particularly from the industrial sector, has not always been matched by the ability of domestic generation supply to meet it, and imports from neighboring countries, particularly Thailand, accounted for around $20 \%$ of domestic consumption during $2009-2016 .{ }^{59}$ In $2017,85 \%$ of imports came from Thailand, with the EGAT transmission system accounting for $66 \%$ of imports and approximately $19 \%$ from the low-voltage grids of Thailand's Provincial Electricity Authority (PEA) (footnote 15). Figure 18 highlights the composition of the Lao PDR's imports during 2017 and their higher magnitude during the dry season.

The country's reliance on power imports has especially been the case during the peak of the dry season in January-April, as precipitation and Mekong River flows, which drive hydropower generation, reach maximum levels between July and September each year. The tightness caused by this counter-cyclicality of higher domestic demand (which peaks during April and May) and lower hydropower generation has resulted in brownouts for large industrial users in the central 2 and southern grids in the past.

Against the backdrop of the Lao PDR now being a major exporter of power to Thailand, the latter's ability—via EGAT and PEA—to still provide flexible supply

59 Footnote 58. Électricité du Laos. 2016. Country Presentation. Presentation prepared for the 21st Meeting of the Regional Power Trade Coordination Committee. Siem Reap. 8-9 December; Government of the Lao PDR, Ministry of Energy and Mines. 2018. Electricity Statistics 2017. Vientiane. 


\section{Figure 18: Electricity Imports from Neighboring Countries to the Lao People's Democratic Republic in 2017 and Average Precipitation, 1960-2005}

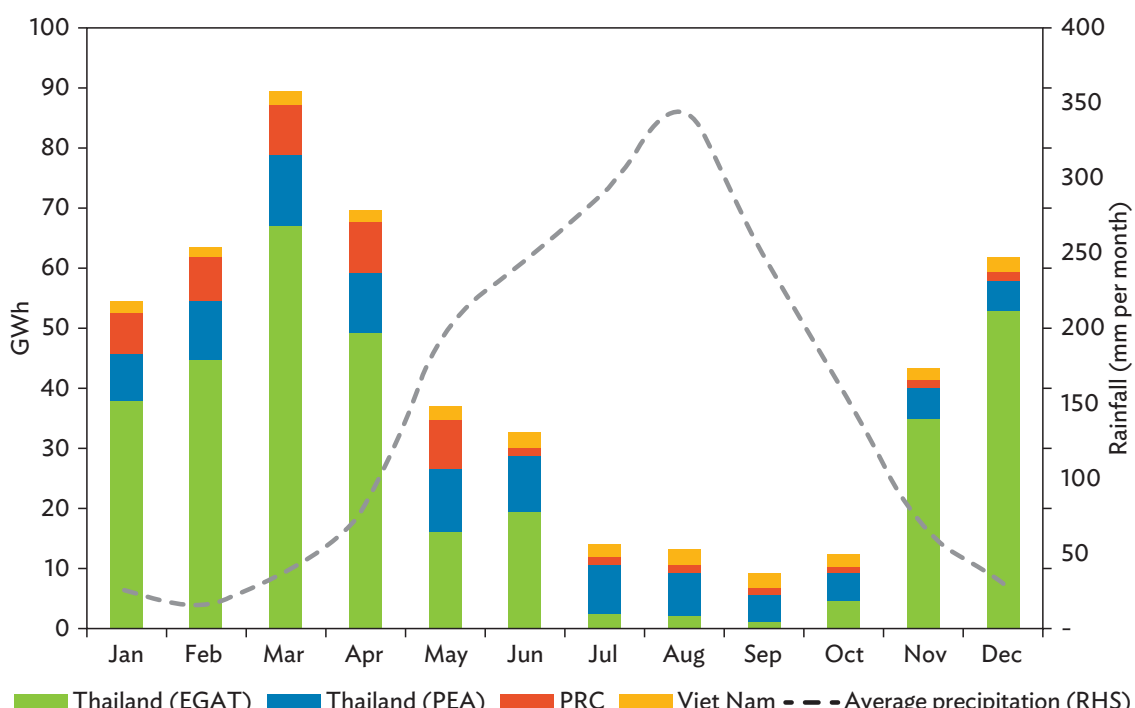

EGAT = Electricity Generating Authority of Thailand, GWh = gigawatt-hour, Lao PDR $=$ Lao People's Democratic Republic, $\mathrm{mm}=$ millimeter, $\mathrm{PEA}=$ Provincial Electricity Authority (Thailand), RHS = right-hand side axis.

Note: EGAT imports include electricity supplied to the Sepon mine.

Sources: Électricité du Laos. 2016. Country Presentation. Presentation prepared for the 21st Meeting of the Regional Power Trade Coordination Committee. Siem Reap. 8-9 December; Government of the Lao PDR, Ministry of Energy and Mines. 2018. Electricity Statistics 2017. Vientiane; World Bank. Climate Change Knowledge Portal. http://sdwebx.worldbank.org/climateportal/ (accessed 3 March 2018).

during periods of seasonal tightness in the Lao PDR offers a good example of regional cooperation within the Greater Mekong Subregion (GMS). Most imports of power from the PEA are to the central 2 and southern grids and, while offsetting seasonal swings in hydropower generation, have also been required to supply burgeoning growth in the mining sector and within special economic zones. ${ }^{60}$

Given the significant increase in domestic capacity build-out and the continued rise in adjusted reserve margin expected in the next few years, MEM expects that imports will no longer be needed within the next 2 years, even during the dry season. However, the inability of EDL to pass the costs of these imports to end-users through the prevailing tariff regime has been one of the several factors contributing to EDL's precarious financial position.

The cost of imported power through trading with EGAT has broadly matched the price of EDL's energy sales, with spot sales by EGAT priced at a wholesale level. During 2011-2013, the prices averaged around \$43/megawatt-hour (MWh) (footnote 59) and were $\$ 40 / M W h$ in 2016, slightly below the wholesale price of

60 Savan-Seno Special Economic Zone (SEZ), Phoukhyo SEZ, and Thakhek SEZ are all in the central 2 region. 
domestic power from EDL-Gen of $\$ 50 / M W h .{ }^{61}$ In 2015, the estimated price of all sales of power to Thailand, spot and under PPAs, was close to $\$ 35 / \mathrm{MWh},{ }^{62}$ and the price of spot sales in 2016 was $\$ 37 / \mathrm{MWh}$ (footnote 61).

However, EDL's purchases of spot power from PEA have been priced at prevailing retail rates and have been expensive, as they include demand charges and wheeling rates. During 2010-2013, the cost of these imports ranged from $\$ 100 / \mathrm{MWh}$ to $\$ 120 /$ MWh (footnote 59) and was $\$ 103 /$ MWh in 2016 (footnote 61). Volumes imported from the PEA in 2016 represented only $20 \%$ of the volumes imported from EGAT, the higher price meant that the PEA accounted for $33 \%$ of the cost (\$32 million) of all imported power.

\subsection{Transmission and Cross-Border Exports}

The Lao PDR's transmission network is operated by EDL and comprises four grid regions across the north, central 1, central 2, and south. Grid expansion and development undertaken during 2009-2011 resulted in a now moderately interconnected transmission grid; before this, each regional grid operated as discrete 115-kilovolt ( $\mathrm{kV}$ ) systems, while the central region was split into central 1 and central 2. As of 2017, the national high-voltage transmission network consisted of 11,301 kilometers $(\mathrm{km})$, predominantly $115 \mathrm{kV}$ and $230 \mathrm{kV}$ lines, with only $462 \mathrm{~km}$ rated at $500 \mathrm{kV}$ (footnote 15).

Several high-voltage lines exist and are used for exports. Three $500 \mathrm{kV}$ lines and two $230 \mathrm{kV}$ lines are dedicated for export to Thailand. Two additional $230 \mathrm{kV}$ lines are for export to Viet Nam. Seven $115 \mathrm{kV}$ lines facilitate power exchange between Cambodia (1), the PRC (1), and Thailand (5). Nineteen medium-voltage ( $22 \mathrm{kV}$ and $35 \mathrm{kV}$ ) lines are dedicated for import from all five neighbors: Cambodia (1), Myanmar (1), the PRC (3), Thailand (7), and Viet Nam (7). ${ }^{63}$ While the majority of high-voltage transmission lines are owned by EDL, five export-oriented IPP projects also have dedicated transmission lines to interconnect directly with EGAT's grid (footnote 59 ).

Transmission and distribution losses have exhibited a downtrend since 2000 and have stabilized around 10\%-13\% since 2009 (Figure 19). This improvement has been brought about by grid reinforcement and upgrading of power transmission and distribution systems, and, as suspected, by a reduction in nontechnical losses. Further improvements to the transmission and distribution systems were outlined in the long-term transmission development plan presented by EDL at the 21st meeting

61 Government of the Lao PDR, Ministry of Energy and Mines. 2017. Electricity Statistics 2016. Vientiane; and EDL-Generation Public Company. 2017. Presentation Thailand Focus 2017. Investor Relations presentation. Vientiane. http://www.edlgen.com.la/presentations/?lang=en.

62 Comtrade data on the value of electric exports, divided by the team's model estimate of power exported under PPAs and EDL 2016 statistics on the volume of spot sales.

63 EDL. 2018. Current Situation and Future Plan of Lao Power Generation, Transmission and Interconnection in GMS Countries. Presentation prepared for the 1st Laos-Myanmar Joint Working Committee Meeting on Power Cooperation. Nay Pyi Taw. 25 May. 
Figure 19: Transmission and Distribution Grid Losses in the Lao People's Democratic Republic, 2000-2016

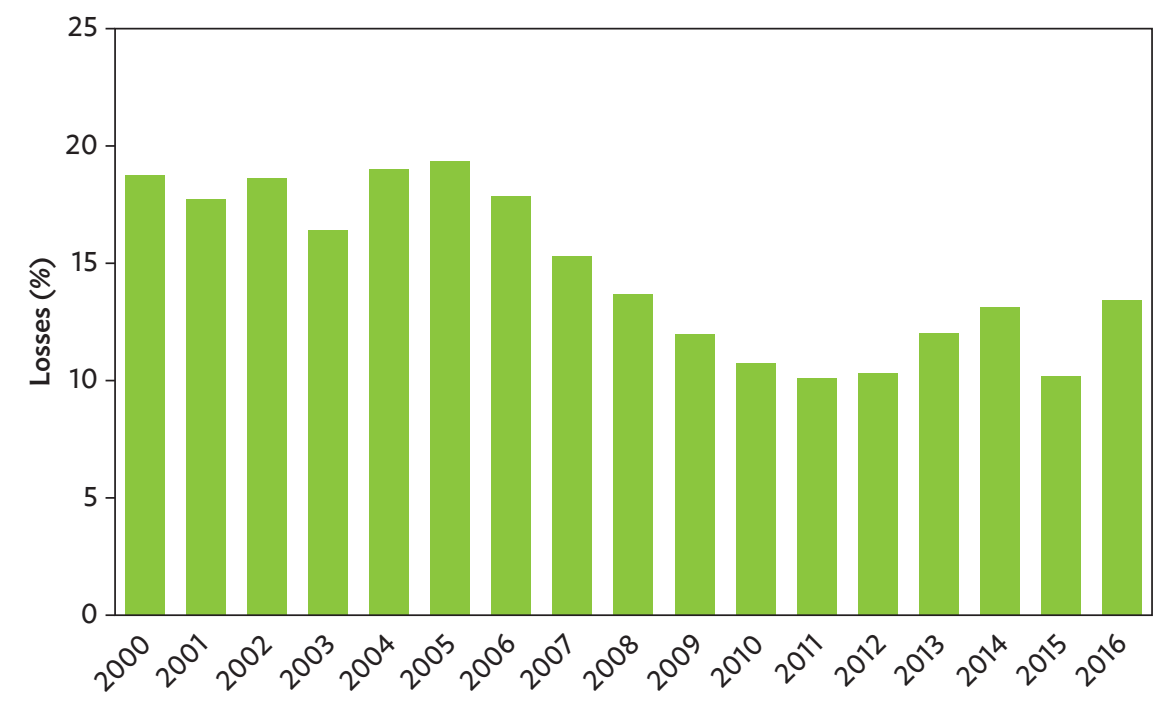

Source: Électricité du Laos. 2017. Electricity Statistics 2016. Vientiane; and Électricité du Laos. 2016. Country Presentation. Presentation prepared for the 21st Meeting of the Regional Power Trade Coordination Committee. Siem Reap. 8-9 December.

of the Regional Power Trade Coordination Committee (RPTCC) in December 2016. Notwithstanding, losses have risen slightly in recent years for unclear reasons.

The disparity between peak demand by region and the capacity for the domestic market in each region highlights the need for adequate transmission to meet peak demand. Installed capacity is well over peak demand in the northern and central 1 regions, but the demand-supply balance is much tighter in the central 2 region, for instance, particularly when considering the seasonality risks associated with hydropower generation (Figure 20).

Based on the regional misalignment of demand-supply balances, it is evident that some capability strengthening in system planning could help the Lao PDR improve the technical, and thus economic, efficiency of its power grid. Furthermore, the EDL grid lacks any formal provision for ancillary services, and the governor control function of generating units is not managed properly. As a result, EDL essentially relies on the neighboring EGAT transmission grid, with which it is interconnected, to implicitly provide frequency response. ${ }^{64}$ While the Lao Grid Code refers to frequency control and voltage levels, many of them are not implemented due to lack of resources.

In the near- to medium-term, the underdeveloped nature of the EDL transmission grid raises significant issues in terms of its technical fragility, geographic scope, and ability to accommodate the considerable amount of new domestic capacity coming

64 The same arrangement is true for Cambodia and its reliance on the Viet Nam grid. 
Figure 20: Regional Peak Demand and Installed Capacity for Domestic Consumption in the Lao People's Democratic Republic, 2017

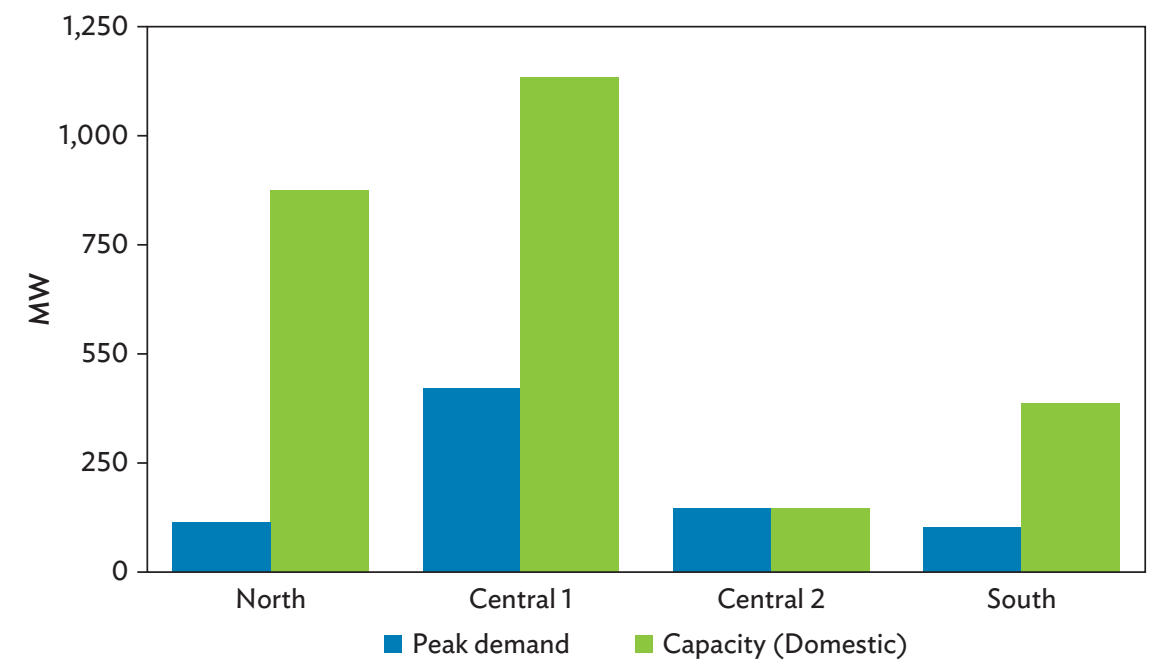

$\mathrm{MW}=$ megawatt

Sources: Tokyo Electric Power Company Holdings, Inc. and Hokuriku Electric Power Company, Inc. 2017. Study on Independent Power Producers (IPPs) in the Lao PDR; Government of the Lao PDR, Ministry of Energy and Mines. 2018. Electricity Statistics 2017. Vientiane; Électricité du Laos. 2016. Country Presentation. Presentation prepared for the 21st Meeting of the Regional Power Trade Coordination Committee. Siem Reap. 8-9 December; and Government of the Lao PDR, Ministry of Energy and Mines. 2016. Power Development Plan 2016-2030. Vientiane; and ADB. 2017. Lao PDR: Accelerating Structural Transformation for Inclusive Growth: Country Diagnostic Study. Manila.

online. In the longer term, and when combined with the lack of harmonization of technical standards, it also highlights the challenges in any implementation of regional power trading arrangements either within the GMS or across the ASEAN regional bloc. Indeed, ASEAN countries are working toward setting up arrangements for electricity swaps and trading within the region via the ASEAN Power Grid, with the Lao PDR as a key proponent of the initiative as it seeks to export more electricity.

Seeking to address these issues, the Japan International Cooperation Agency (JICA) started a 25-month collaboration with MEM's Department of Energy Policy and Planning and EDL in September 2017, aimed at developing a national transmission master plan. ${ }^{65}$ Among the projects being considered are high-voltage transboundary interconnections (discussed further in section 5.1.2).

It is important to note that introducing regional power trading will also invariably face challenges beyond the technical domain and in establishing a robust regulatory environment that has the buy-in of all counterparts. Issues that will need to be overcome include arrangements and charging for wheeling, settlement, and apportioning taxes and duties, and how to facilitate open access.

65 JICA. 2017. The Study on Power Network System Master Plan in the Lao PDR: Interim Report 1. 


\subsubsection{Existing Cross-Border Arrangements}

Owing to its central position within the GMS and vast hydropower potential, the Lao PDR has held long-standing ambitions to be a major provider of cross-border power exports. Power exports currently account for around two-thirds of hydropower generation and represent 15\% of the country's export earnings, being eclipsed by copper and copper ores that account for a combined $25 \%$ of exports. ${ }^{66}$

The country currently has 32-33 interconnections with its neighbors, including Cambodia (2), Myanmar (1), the PRC (4), Thailand (17), and Viet Nam (7) (footnote 59). MOUs and cooperation agreements are in place to supply Thailand (up to $9 \mathrm{GW}$ ), ${ }^{67}$ Viet Nam (up to $5 \mathrm{GW}$ ), ${ }^{68}$ and Cambodia (up to $1.5 \mathrm{GW}$ ) by 2020. MEM has also signed an MOU with Myanmar's Ministry of Electricity and Energy with a view to securing exports for 300-500 MW.

Thailand has continued to be the main off-taker of exported power. Exports to Viet Nam have begun only recently with around $1 \mathrm{GW}$ at present and MEM expecting a further 1.5 GW by 2025. In September 2017, the Lao PDR signed an energy purchase and wheeling agreement with Malaysia and Thailand, representing the first multilateral energy exchange or trade in the ASEAN and facilitating multilateral cross-border power trade beyond the Lao PDR's immediate neighbors. Under the 2-year agreement, the Lao PDR is to sell up to $100 \mathrm{MW}$ of electricity to Malaysia via Thailand's power transmission grid, beginning on 1 January 2018. ${ }^{69}$

\subsubsection{Near-Term Transmission Expansion Plans}

Through its existing long-term PDP, the Lao PDR has considerable plans for the development of transmission infrastructure, the aims of which are two-fold: (i) to facilitate growth and improve resiliency in domestic supply and consumption and (ii) to enable increased cross-border exports. As discussed in section 3.3, the government is ultimately aspiring to facilitate cross-border power trade through gridto-grid interconnections rather than through plant-specific, dedicated export lines at present.

The country has plans to install 25 more transmission lines and associated substations by 2025 (footnote 59). Plans include nine new cross-border high-voltage lines, six of which will be owned by EDL, including the first high-voltage transmission line for export to Myanmar. Owing to the lack of progress with financing and intergovernmental MOUs, it is unclear how much of the government's plans will be realized. The transmission grid development in the Lao PDR is also essential for creating an integrated power market in the GMS - a common goal of the GMS

66 United Nations. UN Comtrade Database. https://comtrade.un.org (2016 data, accessed 12 January 2018).

67 Export MOUs signed with the Thailand government: (1993 up to 3 GW, 1996 up to 7 GW, 2016 up to $9 \mathrm{GW}$ ).

68 Export MOUs signed with the Viet Nam government: (1998 up to 3 GW; 2006 up to 5 GW).

69 S. Vaenkeo. 2017. Laos Sells 100 MW Electricity to Malaysia. Vientiane Times. 29 September. http://annx. asianews.network/content/laos-sells-100mw-electricity-malaysia-57501; and The Economist Intelligence Unit. 2017. Laos, Thailand and Malaysia Sign Energy Deal. 3 October. http://www.eiu.com/industry/ article/895958473/laos-thailand-and-malaysia-sign-energy-deal/2017-10-03. 
Map 2: Électricité du Laos Near-Term Transmission Expansion Plans in the North, Central 1, Central 2, and Southern Grids

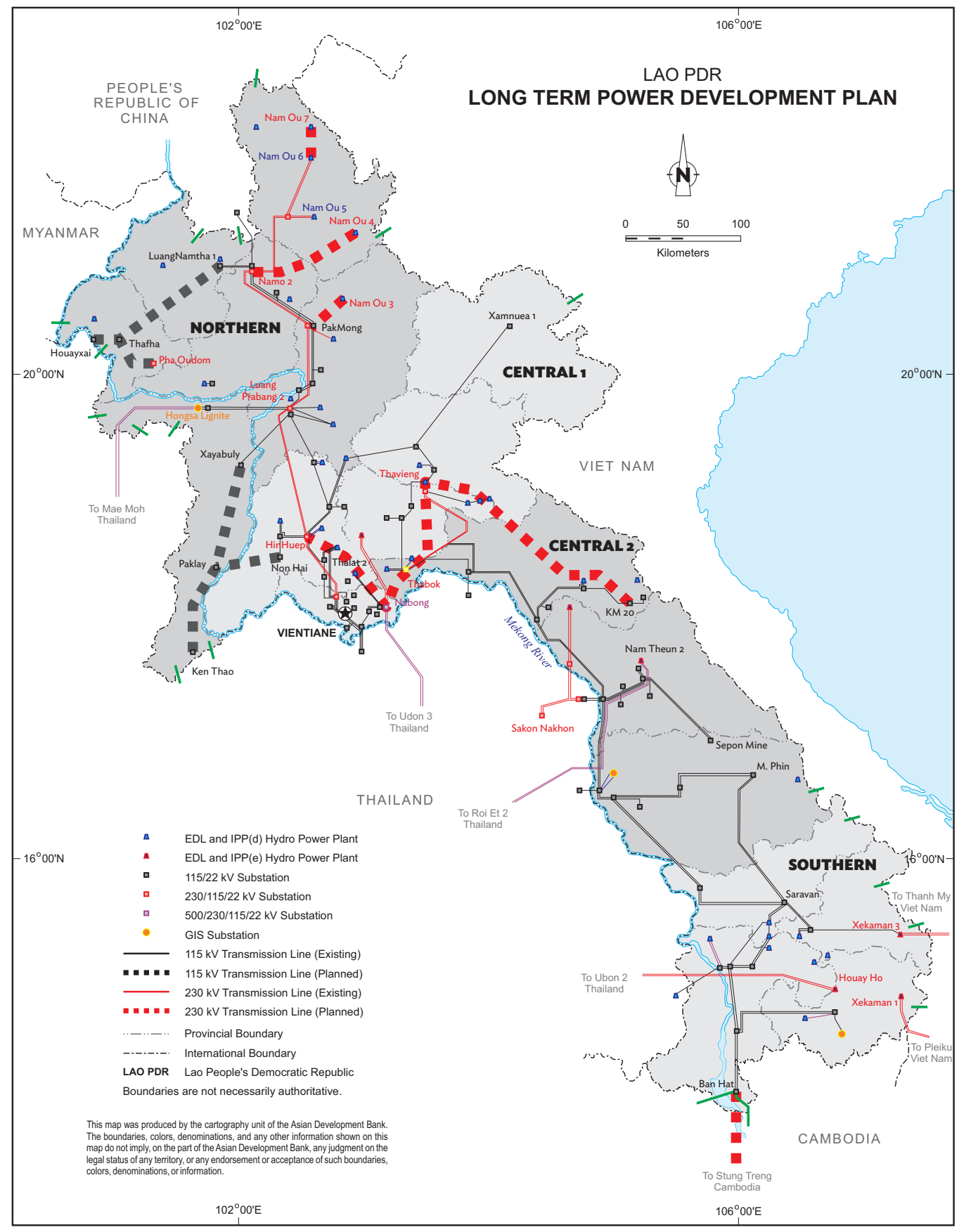

181956C 18LAO ABV

$\mathrm{kV}=$ kilovolt.

Source: Électricité du Laos. 2016. Country Presentation. Presentation prepared for the 21st Meeting of the Regional Power Trade Coordination Committee. Siem Reap. 8-9 December. 
countries. Although the aforementioned lack of technical standards and need for harmonization are pressing concerns.

Significant improvements and extensions to the high-voltage transmission grid will also serve to mitigate regional imbalances in supply-demand and reduce the risk of brownouts, which have affected large industrial users in the past, such as the openpit copper mine in Sepon. In the north and central 1 regions, the transmission grid will be expanded through six $115 \mathrm{kV}$ lines of $458 \mathrm{~km}$ and six $230 \mathrm{kV}$ lines of $216 \mathrm{~km}$, while in the central 2 and southern regions, near-term capacity expansion is limited to two $230 \mathrm{kV}$ lines of $247 \mathrm{~km}$ (Map 2). Further information on transmission infrastructure development is provided in section 5.2 and Annex B of this report.

\subsection{Distribution and Tariffs}

According to EDL, combined transmission and distribution losses have ranged between $10 \%$ and $13 \%$ in recent years, as referred to in Figure 19. The exact percentage attributable to the distribution grid is not known, although EDL's Technical Department suggests it to be around 9\%. Notwithstanding, and based on general trends in other emerging markets, much of the losses are likely to be in the lower voltage, $22 \mathrm{kV}$ distribution part of the delivery system.

EDL has targets to reduce distribution losses by $0.5 \%$ per annum and, to that end, is currently developing a pilot project in collaboration with the World Bank and has ongoing assistance from ADB's power distribution investment programs. ${ }^{70}$ One particular challenge is that network automation is low, and only new substations can be monitored remotely. Bilateral aid agencies are also offering assistance, and EDL has shown interest in this area for potential support from Agence Française de Développement (AFD) (footnote 28). EDL highlighted the needs for improvements of the Vientiane distribution grid and the establishment of a distribution master plan for Vientiane area as possible future areas of partnership.

The World Bank Group Enterprise Survey has revealed in several recent editions that a high percentage of companies identified electricity as a major constraint on their business (over 17\% in 2018). ${ }^{71}$ The worst of the outages are in central 2 and south regions, and, compared with its peers within the ASEAN bloc, the Lao PDR has bigger system average interruption duration index and system average interruption frequency index, indicating considerable room for improvement (Table 4).

70 World Bank. 2015. Lao PDR to Improve Electricity Network with World Bank Support. News. 23 June. http:// www.worldbank.org/en/news/press-release/2015/06/23/lao-pdr-to-improve-electricity-network-withworld-bank-support.

71 World Bank. 2018. Enterprise Surveys: Lao PDR. http://www.enterprisesurveys.org/data/ exploreeconomies/2018/lao-pdr\#infrastructure. 


\section{Table 4: System Average Interruption Duration Index and System Average Interruption Frequency Index within Southeast Asia, 2013-2015}

$\begin{array}{lcccccccc}\text { Country } & \text { CAM } & \text { IND } & \text { LAO } & \text { MAL } & \text { PHI } & \text { SGP } & \text { THA } & \text { VIE } \\ \text { SAIDI } & 63 & 3.5 & 49 & 0.5 & 5.4 & 0.01 & 0.7 & 27 \\ \text { SAIFI } & 48 & 2.4 & 94 & 0.5 & 3.1 & 0.01 & 1.5 & 11\end{array}$

CAM = Cambodia, IND = Indonesia, $\mathrm{LAO}=$ Lao People's Democratic Republic, MAL = Malaysia, $\mathrm{PHI}=$ Philippines, $\mathrm{SAIDI}=$ System Average Interruption Duration Index, SAIFI = System Average Interruption Frequency Index, SGP = Singapore, THA = Thailand, VIE = Viet Nam .

Source: World Bank. 2017. Electricity Tariffs, Power Outages and Firm Performance: A Comparative Analysis. Washington, DC.

\subsubsection{End-User Tariffs}

With input and support from major development partners, the government has developed a policy to gradually increase electricity tariffs to cover production, transmission, and distribution costs. Based on the government's decision in March 2012, electricity tariffs were to increase on average by 2\% or more annually. From 2009 to 2017 , average tariffs grew at a CAGR of $2.9 \%$ in $\$ / \mathrm{kWh}$ terms $(\$ 0.0805 / \mathrm{kWh})$ and $2.2 \%$ in $\mathrm{KN} / \mathrm{kWh}$ terms (KN649/kWh), having been moderated from their highpoint in 2015 (footnote 58). Yet despite these increases, overall tariff rates in the Lao PDR are low and remain below cost recovery; during 2015, tariffs were approximately $\$ 0.0200 / \mathrm{kWh}$ below the average cost incurred by EDL, with this gap growing to $\$ 0.0441$ in 2016 (footnote 15). Moving forward, EDL is focusing on reducing power purchase costs by $2 \%$ and distribution losses by $1.5 \%$ to maintain a $2 \%$ tariff increase (footnote 11).

At present, residential tariffs are considerably lower than for general business or high-voltage customers (large businesses), indicating a degree of cross-subsidization when compared with EDL's total average cost per MWh (Figure 21). While many residential end-users also benefit from tariff subsidization, these subsidies are both expensive and untargeted, and, together with a lack of cost-reflective tariffs, are important factors impairing EDL's financial position. Subsidies are discussed further in section 5.1 .

Despite the current tariff regime expiring at the end of 2017, the 2017 tariff remains in effect while MEM prepares a new tariff decree through 2022 as part of their financial review of EDL and the Lao PDR power sector. ${ }^{72}$

In designing new tariffs, challenges and delays have resulted from the need to separate EDL's investment expenditure for domestic and export-related transmission infrastructure to ensure that the domestic market only bears costs for which it is responsible. The aims of the Lao PDR for inclusive economic development serve as a challenge for the government to implement the new tariff regime without adversely affecting the poor; small users will likely continue to pay non-cost reflective tariffs. In

72 Government of the Lao PDR. Ministry of Mines and Energy and Électricité du Laos. 2019. Financial Action Plan. Vientiane. 
Figure 21: Tariff Trends of Key Customer Classes and Average Cost of Supply in the Lao People's Democratic Republic

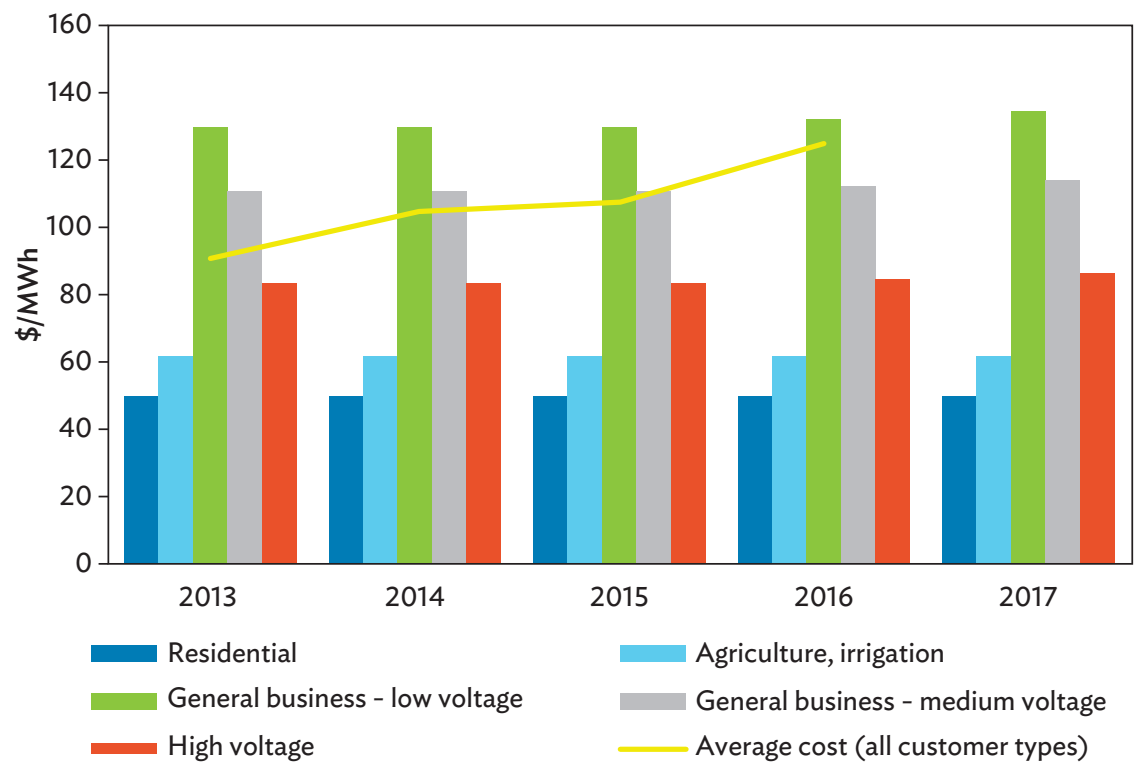

$M W h=$ megawatt-hour.

Sources: Électricité du Laos. 2016. Country Presentation. Presentation prepared for the 21st Meeting of the Regional Power Trade Coordination Committee. Siem Reap. 8-9 December; Électricité du Laos. 2016 Financial Statements.

fact, larger residential users (with consumption of greater than $150 \mathrm{kWh}$ per month) already pay twice the rate of residential users in the 25-150 kWh bracket.

\subsection{Climate Change and the Environment}

The Lao PDR has a long and deep-rooted history of being fundamentally intertwined with its natural environment and resources shaped by the Mekong River along its western frontier; a land area of which $80 \%$ is covered by natural forest, forest plantation, and unstocked forest; and an economy founded on agriculture. The country is considered to be particularly vulnerable to the effects of climate change, both at the economic and social levels. ${ }^{73}$ Its location within the Mekong River gives rise to the potential for extreme climatic hazards such as flooding and droughts, which may have a material impact on vital areas such as agricultural cycle and food security as well as water supply and hydropower production.

As a consequence, the country has had a long-standing and progressive policy agenda for reducing greenhouse gas emissions and addressing climate change, having first approved the National Strategy on Climate Change in early 2010. The strategy was followed a year later by the Renewable Energy Development Strategy,

73 Government of the Lao PDR. 2015. Intended Nationally Determined Contribution. Vientiane. 
2011-2025, which included financial incentives, such as reduced import duties and tax incentives, and a legal framework to support the development of economically viable technologies and promote competition. ${ }^{74}$ Ultimately, the aim is to increase renewable energy use-excluding large hydropower-to $30 \%$ of total energy consumption by 2025 , with biofuel production accounting for $10 \%$ of total energy consumption in transport (footnote 74). Despite the incentives and measures provisioned by the strategy, the implementation of new renewable technologies in the country has been limited so far (section 2.1), suggesting that the economics of renewable technologies remains not sufficiently attractive at present, that there are difficulties in implementing these plans, or a combination of both.

In addition, the Renewable Energy Fund is to be introduced as a part of the Renewable Energy Development strategy and as a sub-account of the Rural Electrification Fund, with the intention of providing financial assistance and removing financial barriers to promote the development of renewable energy (footnote 74). On the issue of energy efficiency, the government is aiming for a reduction of $10 \%$ of energy consumption by 2030 compared to the business-as-usual outlook. ${ }^{75}$

Other policies aimed at adapting to and mitigating the effects of climate change have since included the following:

- $\quad$ Climate Change Action Plan of the Lao PDR (2013-2020);

- Investment and Financial Flows to Address Climate Change in Energy, Agriculture, and Water Sector (2015);

- National Adaptation Programmes of Action for Climate Change;

- Intended Nationally Determined Contribution (INDC); and

- Nationally Appropriate Mitigation Actions for the Renewable Energy Sector of the Lao PDR. ${ }^{76}$

Given the Lao PDR's rich hydro resource potential, the development of hydropower projects has naturally served as one of the central thrusts behind the country's climate-focused policies. To date, large hydropower development has mostly been a result of FDI under build-operate-transfer (BOT) and build-own-operate-transfer schemes. FDI seems poised to remain the main source of such new development, with financial strains of local developers such as EDL and its subsidiaries limiting their ability to develop capital-intensive hydro projects. There are also explicit policies to promote large hydro, such as those stated under the INDC, as outlined in Table 5.

Government of the Lao PDR. 2011. Renewable Energy Development Strategy in Lao PDR. Vientiane.

75 World Bank. Worldwide Governance Indicators. http://info.worldbank.org/governance/wgi/\#home (accessed 1 July 2017).

76 The National Adaptation Programmes of Action for Climate Change is from: World Bank Group. 2016. Lao People's Democratic Republic: (Intended) Nationally Determined Contribution-(I)NDC. Washington, DC. 
More recently, the Lao PDR signed the climate treaty known as the Paris Agreement, with its ratification taking effect on 4 November 2016. ${ }^{77}$ Through the country's INDC, several programs and measures were identified to improve resilience to climate change and reduce future greenhouse gas emissions. The activities to be implemented under the INDC are summarized in Table 5, including the corresponding objectives and estimated resulting carbon dioxide equivalent reductions in emissions.

The INDC sets out adaptation projects for some of its key sectors in addition to the mitigation-related activities in Table 5. These include promoting resiliency and adaptability to climate change in sectors such as agriculture, forestry and land use change, water resources, transport and urban development, and public health. Implementation of the INDC will be facilitated by the Ministry of Natural Resources

\section{Table 5: Intended Mitigation Activities to be Implemented by the Lao People's Democratic Republic in 2015-2020}

\begin{tabular}{|c|c|c|}
\hline Name of Activity & Objectives of Activity & $\begin{array}{l}\text { Estimated } \mathrm{CO} 2 \mathrm{e} \\
\text { Reduction }\end{array}$ \\
\hline $\begin{array}{l}\text { Implementation of Forestry } \\
\text { Strategy to the Year } 2020\end{array}$ & $\begin{array}{l}\text { To increase forests to cover } 70 \% \text { of land area } \\
\text { by } 2020\end{array}$ & $\begin{array}{l}60,000-69,000 \mathrm{ktCO} 2 \mathrm{e} \\
\text { (once the forestation } \\
\text { target is met by } 2020 \\
\text { onward) }\end{array}$ \\
\hline $\begin{array}{l}\text { Implementation of Renewable } \\
\text { Energy Development Strategy }\end{array}$ & $\begin{array}{l}\text { (i) To increase the share of renewable energy } \\
\text { to } 30 \% \text { of energy consumption by } 2025 \\
\text { (ii) To increase the share of biofuels to meet } \\
10 \% \text { of the demand for transport fuels by } 2025\end{array}$ & $\begin{array}{l}\text { 1,468,000 ktCO2e (by } \\
2025 \text { ) }\end{array}$ \\
\hline $\begin{array}{l}\text { Implementation of Rural } \\
\text { Electrification Programme }\end{array}$ & $\begin{array}{l}\text { To make electricity available to } 90 \% \text { of } \\
\text { households in rural area by } 2020 \\
\text { Note: this target has already been surpassed } \\
\text { and subsequently adjusted upward to } 95 \% \text { in } \\
2020 \text {. }\end{array}$ & $\begin{array}{l}63 \text { ktCO2e per annum } \\
\text { (once the target is met in } \\
\text { 2020) }\end{array}$ \\
\hline $\begin{array}{l}\text { Implementation of transport- } \\
\text { focused NAMAs }\end{array}$ & $\begin{array}{l}\text { To further develop the road networks and } \\
\text { increase the use of public transportation }\end{array}$ & $\begin{array}{l}33 \text { ktCO2e per annum } \\
\text { for road network } \\
\text { development and } 158 \\
\text { ktCO2e per annum } \\
\text { for public transport } \\
\text { development }\end{array}$ \\
\hline $\begin{array}{l}\text { Expansion of the use of large- } \\
\text { scale hydroelectricity }\end{array}$ & $\begin{array}{l}\text { To build largescale ( }>15 \mathrm{MW} \text { ) hydropower } \\
\text { plants to provide clean electricity to } \\
\text { neighboring countries } \\
\text { Approximately } 5,500 \mathrm{MW} \text { of total installed } \\
\text { capacity by } 2020 \text { and } 20,000 \mathrm{MW} \text { of } \\
\text { additional hydroelectric capacity are planned } \\
\text { for construction after } 2020 \text {. }\end{array}$ & $\begin{array}{l}\text { 16,284 ktCO2e per } \\
\text { annum (2020-30). }\end{array}$ \\
\hline $\begin{array}{l}\text { Implementation of climate } \\
\text { change action plans }\end{array}$ & $\begin{array}{l}\text { To build capacity to monitor and evaluate } \\
\text { policy implementation success, with a view to } \\
\text { producing new policy, guidance, and data }\end{array}$ & $\begin{array}{l}\text { To be estimated as part of } \\
\text { the implementation plan }\end{array}$ \\
\hline
\end{tabular}

77 United Nations Framework Convention on Climate Change. Paris Agreement - Status of Ratification. http:// unfccc.int/paris_agreement/items/9444.php. 
and Environment, whose approach will focus on four elements: (i) overall strategy, coordination of INDC implementation, and regulatory framework; (ii) capacity building; (iii) finance; and (iv) monitoring, reporting, and verification. In total, the mitigation and adaptation projects would cost approximately $\$ 2.37$ billion, with significant capacity building required. The financial situation of the Lao PDR is similar to other developing nations, insofar as its commitments to tackling climate change are contingent upon international support (footnote 76).

\subsubsection{Linkages between the Power Sector and the Environment}

While the continued development of hydropower capacity in the Lao PDR appears compatible with the country's commitment to tackling climate change, it is premature to view it as a panacea. The propensity for climate change to potentially alter or diminish the hydrological resources upon which such infrastructure relies presents risks to the operations and viability of hydropower generation over their lifetime (50-60 years is typical). In its climate change impact assessment of the Nam Ngiep 1 Hydropower Project, the International Centre for Environmental Management identified the following distinct risks posed by climate change:

(i) performance risks: sensitivity of generation to reservoir inflows due to daily, weekly, and seasonal changes in rainfall and evaporation rates;

(ii) reservoir life risks: the useful operating life of a hydropower plant can be impinged by increased sediment loads, which reduce the amount of reservoir storage;

(iii) safety risks: increasing risk and intensity of extreme flooding events that can potentially threaten the structural integrity of a dam;

(iv) secondary risks: land subsidence or slippage that can threaten dam integrity or block upstream water flows, with a resultant impact on generation;

(v) environmental risks: increasing water temperatures that can endanger the aquatic environment and biodiversity, thereby compromising the environmental compliance of hydropower projects; and

(vi) risks due to changing patterns of water demand: potential for warmer climatic conditions to increase evapotranspiration and reduce water quantities, which may increase competition for water in instances where it is also used for irrigation purposes and not solely electricity generation. ${ }^{78}$

Both small and large hydropower projects pose an array of local environmental risks that can raise concerns about social equity despite being generally considered "carbon neutral" and nonpolluting. In particular, they can often have substantial impacts on local ecosystems, including land, forests, and hydrology, and can lead to the displacement of populations. As these projects tend to be developed in more rural areas, associated economic repercussions on less affluent local populations and local ecological assets can sometimes be perceived as regressive. The impact on local populations and assets creates the impetus to better understand the implications of new project development so that the consequences can be dealt with accordingly.

78 International Centre for Environmental Management. 2015. Climate Change Impact Assessment of the Nam Ngiep 1 Hydropower Project: Final Report. Ha Noi. 
Building on its long history of recognizing the importance of managing its environment and natural resources sustainably, the Lao PDR has sought to better understand and assess the potential environmental impact of power generation projects through the National Policy on Sustainable Hydropower Development, enacted in $2015 .{ }^{79}$ One of the tenets of this policy has been the mandating of strategic environmental assessments (SEAs) to be undertaken when developing policies, strategic plans, and programs within the power sector.$^{80}$ Rather than assessing the impact of an individual project, SEAs aid the overall planning process by providing an integrated evaluation of different generation mix pathways that considers social and environmental impacts, risks, and mitigation actions, as well as alternative development options (footnote 80). SEAs mark a step change away from conventional project-specific planning approaches by providing a holistic approach that seeks to evaluate the full economic cost and implications associated with different power sector development pathways. In turn, this should allow development within the sector to be sustainable from an economic, environmental, and social perspective.

In the Lao PDR, where hydropower generation has been and is likely to continue to be the predominant form of power project development, some of the foremost issues that should be considered by an SEA are the

- impact on hydrology, such as changes in seasonal water flows, flooding, and drought risks;

- resettlement of people displaced by the construction of dams;

- impact on agriculture and livelihoods in local communities, and social cost; and

- $\quad$ impact on forest cover, biodiversity, and natural habitats (footnote 80).

Such holistic project evaluation is not only important from the perspective of evaluating the interplay of negative project externalities with general concerns for social equity and environmental sustainability. Additionally, understanding these environmental issues, along with the local environmental impacts associated with large hydro project development, has wider benefits for these projects. For instance, rampant illegal deforestation has blighted the country for some time, contributing to approximately 140,000 hectares per year (1.25\% per annum) of forests being lost between 1992 and 2002 (footnote 30). The resulting feedback effects-changing the nature of local hydrology and increasing the incidence of landslides-can have substantial repercussions for hydropower projects. To the degree that such a changing environmental situation impacts hydropower projects, it could have negative economic consequences, and to the degree that these impacts are not understood and remain unquantified, they are likely to increase the perceived risk profile of hydropower development in the Lao PDR, and in turn lead to an increase in the cost of capital for such projects.

79 Appendix 5 outlines the history of environmental legislation and relevant aspects pertaining to electricity generation.

80 Government of the Lao PDR, Ministry of Energy and Mines. 2017. Strategic Environmental Assessment in Power Sector Planning in the Greater Mekong Subregion. Vientiane. 
The Lao PDR has yet to realize the full benefit of adopting the SEA framework, as the inclusion of SEA principles in power development planning only extends as far as screening hydropower projects in terms of their proximity to designated protected areas (footnote 55). Further, the absence of non-hydropower forms of renewable energy from the Lao PDR's long-term power development plan (PDP) means that the application of SEA principles cannot be consistently applied (footnote 55). Given that large-scale hydropower is likely to continue to be a mainstay of Lao PDR's electricity sector, it is imperative that the full economic, social, and environmental costs of these projects are studied much more systematically, and that a robust framework for environmental and technical compliance is put in place. A compliance framework will undoubtedly help to alleviate concerns and address consequences associated with these projects regarding social equity, environmental sustainability, and project finance, among other things.

\subsection{Electrification and Access to Electricity}

The Lao PDR is widely recognized as having made significant progress in providing electricity to its citizens, having very successfully implemented its National Electrification Program since the turn of the century. Between 2000 and October 2017, the rate of electrification increased from $36 \%$ (footnote 59) to $94 \%$ (footnote 24), and in turn led the country to surpass its previous target of $90 \%$ electrification by 2020 ahead of schedule..$^{81}$ The Lao PDR's progress in electrification can be considered all the more impressive given the inherent challenges associated around $60.35 \%$ of the country's population living rurally (2016). ${ }^{82}$

While revenues from hydropower exports were critical in funding the first years of the national electrification program, the rapid expansion of access to electricity was a result of several other factors including

- $\quad$ proactive government policies and financial assistance;

- $\quad$ high performance of EDL with regards to leading, planning, and implementing the program in a cost-efficient manner;

- $\quad$ state subsidies and below-cost retail rates for poorer segments of the population;

- implementation of a financing mechanism - Power to the Poor Program - to assist the poorest rural households; ${ }^{83}$ and

- utilization of off-grid solutions for households in remote areas when costeffective. $^{84}$

81 The Lao PDR's previous electrification target of $90 \%$ by 2020 was set under its Energy Policy 2015.

82 World Bank. Rural Population. https://data.worldbank.org/indicator/SP.RUR.TOTL?locations=LA (accessed 18 December 2017).

83 The program is designed to assist the poorest rural households in financing the entire costs of connection and internal wiring up front in an affordable way.

84 World Bank. 2012. Lao PDR: Power to the People: Twenty Years of National Electrification. Washington, DC. http://siteresources.worldbank.org/INTEAPASTAE/Resources/LaoPDR-PowertoPeople.pdf. 
The success of the Lao PDR's electrification program can be seen in Figure 22 (footnote 46).

Despite the impressive headline statistics for electrification, access to electricity still varies substantially by region; around 67,000 households remain without electricity and instead rely on traditional biomass for lighting and cooking (footnote 58). The more densely populated and less mountainous central regions generally have higher rates than the northern and southern regions. The electrification rates by province are shown in Map 3.

The Lao PDR government aims to continue expanding access to electricity under its National Electrification Program and has stated a goal of 95\% electrification by 2020 and $98 \%$ by $2025 .{ }^{85}$ Specifically, in northern provinces where electrification rates are significantly below the national average, such as Phongsaly ( $58.4 \%$ in 2017 ) and Houaphan (73.2\% in 2017), the government has made the development of basic infrastructure, including the extension of power distribution lines, a priority (footnote 55).

\section{Figure 22: National Electrification Levels in the Lao People's Democratic Republic}

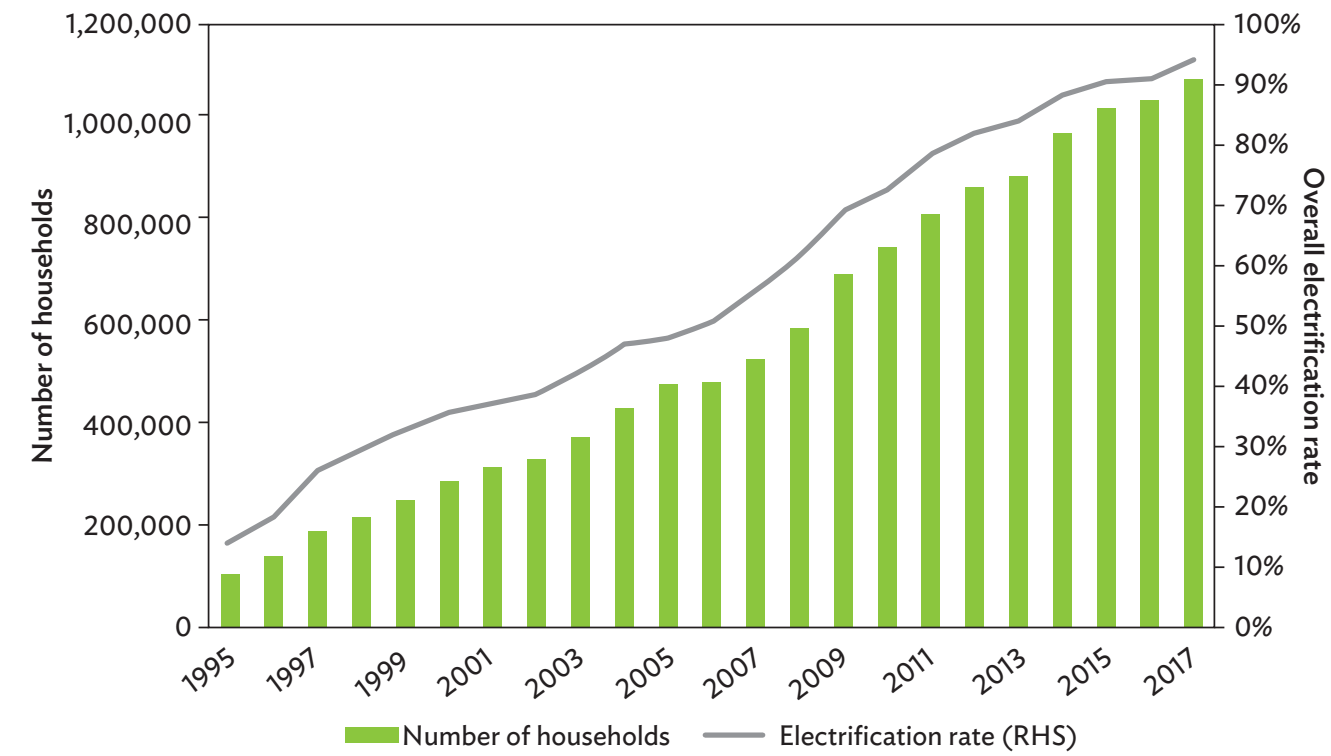

Lao PDR = Lao People's Democratic Republic, RHS = right-hand side axis.

Sources: Électricité du Laos. 2016. Country Presentation. Presentation prepared for the 21st Meeting of the Regional Power Trade Coordination Committee. Siem Reap. 8-9 December; Government of the Lao PDR, Ministry of Energy and Mines. 2018. Electricity Statistics 2017. Vientiane.

85 Government of the Lao PDR, Ministry of Energy and Mines, Institute of Renewable Energy Promotion. 2016. Renewable Energy Data in Lao PDR. Paper prepared for the East and Southeast Asia Renewable Energy Statistic Training Workshop.Bangkok. 12-14 December. 
Map 3: Electrification Rate in the Lao People's Democratic Republic, by Province, as of 2017

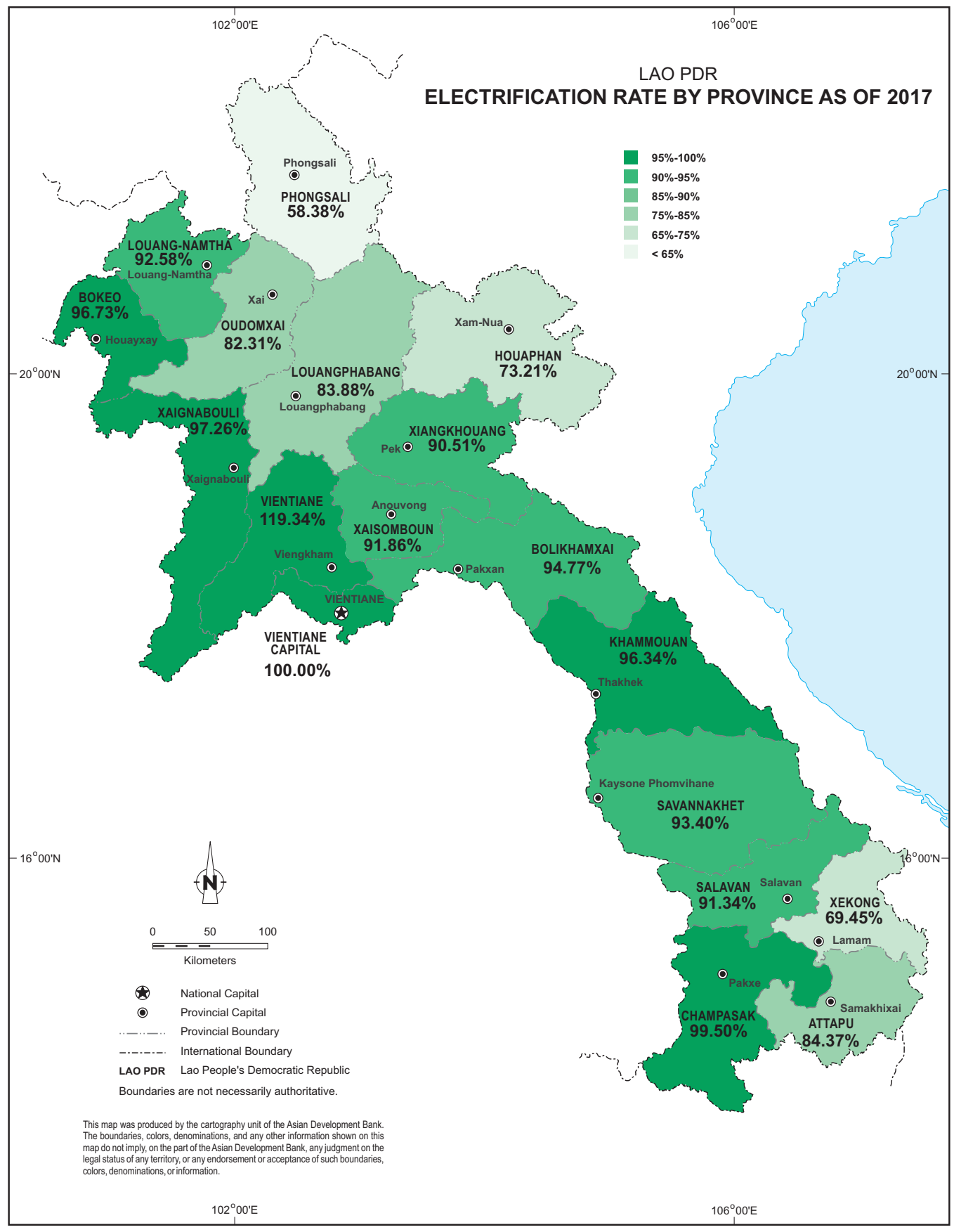

Source: Government of the Lao PDR, Ministry of Energy and Mines. 2018. Electricity Statistics 2017. Vientiane. 
The government's plan to electrify the remaining unconnected households is generally via an extension of the power grid. Inherently, many of the households that remain without electricity live in more inaccessible "last mile" areas and have limited disposable cash income. In such locations, electrification via grid extension proves to be very expensive and does not offer the most cost-effective option. ADB estimates that the marginal cost of electrifying the remaining unelectrified households is more than double the costs of electrifying the previous $15 \%-20 \%$ of households. The relatively unamenable conditions of the remaining unconnected households to traditional grid extension may mean that alternative solutions are more cost-effective in many cases.

In particular, off-grid alternatives such as solar home systems (SHS) or micro-grids are often lower cost solutions to "last mile" electrification issues. Such alternatives have been utilized at times in the Lao PDR. In 2006, 25,000 SHSs introduced via the World Bank-financed Village Off-Grid Promotion and Support program, with 15,775 systems (totaling $590 \mathrm{kWp}$ ) still in operation across. ${ }^{86}$ Though solar power has likely played the most significant role in off-grid electrification initiatives to date, other technologies also play a role in off-grid electrification in the Lao PDR. In 2011, a $3 \mathrm{MW}$ sugarcane bioenergy plant commenced operations in Savannakhet Province, subsequently increasing capacity to $8 \mathrm{MW}$, while a $30 \mathrm{MW}$ bioenergy and ethanol plant in Attapeu Province entered service in $2013 .{ }^{87}$ Several other projects including waste-to-energy technologies are also actively being developed.

As the Lao PDR's remaining population without electricity becomes more difficult and expensive to reach via conventional grid expansion, renewable technologies in off-grid distributed applications are becoming more cost-effective and technically feasible alternatives and should be considered as a means of expanding access to electricity.

\subsection{Energy Efficiency}

The Lao PDR government has not established a framework through which energy efficiency would be implemented. There is no agency tasked with pushing the energy efficiency agenda in the country, nor is there a policy that broadly deals with this issue. Despite lacking an overarching framework, the Lao PDR does have a general energy savings target of $10 \%$ for the period through $2025 .{ }^{88}$

The absence of a formal institutional framework through which to promote energy efficiency and conservation (EEC) programs has seen some programs carried out by various agencies. For instance, the ASEAN-Japan: Promotion of Energy Efficiency

86 Government of the Lao PDR, Ministry of Energy and Mines. 2018. Electricity Statistics 2017. Vientiane. The difference in installed and operational SHSs is due to a combination of poor operation and maintenance practices and some households receiving grid-connected electricity supply.

87 Government of the Lao PDR, Ministry of Planning and Investment. 2016. 8th Five-Year National SocioEconomic Development Plan (2016-2020). Vientiane.

88 ADB. 2015. Energy Efficiency Developments and Potential Energy Savings in the Greater Mekong Subregion. Manila. 
and Conservation and the Ayeyawady-Chao Phraya-Mekong Economic Cooperation Strategy programs were implemented, with the aim of promoting awareness and knowledge of the issues through a series of workshops, seminars, trainings, and energy audits (footnote 88).

Furthermore, the World Bank and Global Environment Facility have funded the twophase Demand Side Management and Energy Efficiency project. Phase 1 activities included energy audits and energy efficiency improvement recommendations, pilot energy efficiency measures, expansion of the public sector energy database, cleaning of air conditioners and installation of various technologies, and awareness building (footnote 88). Phase 2 involved the (i) replacement of 400,000 light bulbs in the residential sector with compact fluorescent light lamps, and lighting and air conditioner units in government buildings; and (ii) continued dissemination of information to promote awareness building regarding energy savings opportunities.

The 2018 amendment to the Lao PDR's Electricity Law mandates MEM to develop policies to implement energy efficiency and conservation measures (and similarly, for the use of alternative forms of energy). A new EEC policy was established in 2017 and an EEC decision is currently under preparation. Additional implementing regulations will need to be promulgated to develop a complete EEC framework. 


\section{Power Sector Constraints}

The power sector in the Lao PDR faces challenges on many fronts, with the following four key areas:

- EDL's financial sustainability and substantial debt burden, as well as the lack of cost-reflective tariffs and high take-or-pay clauses associated with the forthcoming domestic supply surplus;

- $\quad$ meeting the required capital expenditure for transmission infrastructure, both to serve domestic demand and to evacuate excess power to export markets;

- lack of regulation and the need for capacity building within MEM and EDL; and

- realizing hydropower build-out potential.

\subsection{Financial Sustainability of Électricité du Laos}

The build-out of power plant capacity and transmission and distribution in a lower middleincome country such as the Lao PDR has been achieved by balancing low tariff levels that reflect the low ability of the residential sector to pay with subsidy support from the government and concessional financing from the international development agencies.

\subsubsection{Financial Position of Électricité du Laos}

As the single buyer for the domestic market, EDL is responsible for domestic retailing, domestic transmission and distribution, and some generation and wholesale exports. $E D L$ earns revenues from the sale of electricity to domestic and foreign consumers and dividends from some independent power producers (IPPs). However, these combined revenue streams have produced growing losses (Figure 23).

As further illustrated in Table 6, EDL's financial situation is quite precarious and thus relies on implicit or explicit government support. EDL has been financed in large part through government-to-government lending, such as with the PRC. While this has been at attractive interest rates of around 2\%, EDL has paid a "marked up" rate closer to $5 \%$ along with the repayment of the underlying capital. Since 2014, EDL's long-term debt to equity ratio has risen rapidly and is now probably unsustainable. In 2016, EDL Group could not fully service its debt and breached its financial covenants (Table 6). With EDL's liabilities increasing, obtaining further financing becomes even more difficult. 
Figure 23: Électricité du Laos Recurring Revenues, Costs, and Profit/Loss

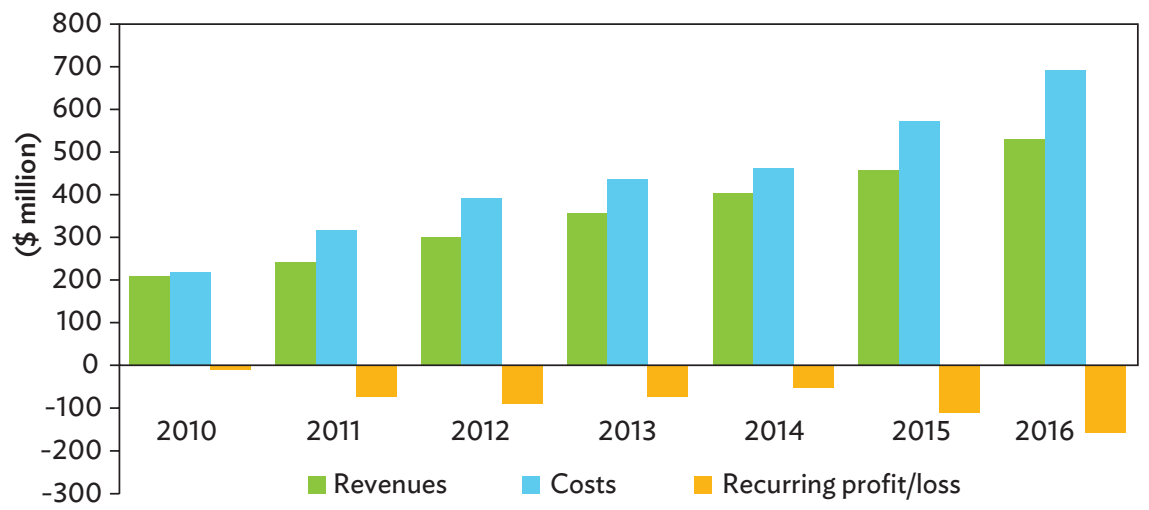

Source: Électricité du Laos. 2010-2016 Financial Statements.

By contrast, EDL's 75\%-owned subsidiary, EDL-Gen, has stakes in many domestic small power producers, IPPs, and some export-oriented IPPs and makes a profit (gross profit in 2016 was around $\$ 157$ million, which largely came from the sales to $E D L)$. Yet, even EDL-Gen's financial ratios are showing some signs of deterioration. Profits are on a downtrend, and debt-to-equity and net debt-to-earnings before interest, taxes, depreciation, and amortization rose sharply in 2016. EDL-Gen's liabilities as of June 2017 amounted to around \$1.1 billion, while a rising accounts receivable figure alludes to the liquidity issues being seen downstream at $E D L$, the single buyer (footnote 35).

\section{Table 6: Électricité du Laos Key Financial Ratios}

\begin{tabular}{|lccc|}
\hline $\begin{array}{c}\text { Long-Term } \\
\text { Debt to Equity } \\
\text { (Nonconsolidated) }\end{array}$ & $\begin{array}{c}\text { Long-Term } \\
\text { Debt to Equity } \\
\text { (Consolidated) }\end{array}$ & $\begin{array}{c}\text { Current Assets / Current } \\
\text { Liabilities (Consolidated) }\end{array}$ \\
\hline 2011 & $1.2 x$ & $1.2 x$ & $0.5 x$ \\
\hline 2012 & $1.3 x$ & $1.3 x$ & $0.6 x$ \\
\hline 2013 & $1.6 x$ & $1.8 x$ & $0.3 x$ \\
\hline 2014 & $2.3 x$ & $2.5 x$ & $0.5 x$ \\
\hline 2015 & $2.8 x$ & $3.3 x$ & $0.3 x$ \\
\hline 2016 & $4.4 x$ & $5.4 x$ & $0.5 x$ \\
\hline Financial covenant/ & $<=1.5-2.0 x$ & $<=1.5-2.0 x$ & $>=1.0 x$ \\
target & & & \\
\hline
\end{tabular}

Source: ADB estimates. 
Table 7: EDL-Generation Public Company Key Financial Ratios

\begin{tabular}{lcccccc} 
& EBITDA & Net Debt & $\begin{array}{c}\text { Equity } \\
2011\end{array}$ & $\begin{array}{c}\text { Net Debt/ } \\
\text { Equity }\end{array}$ & $\begin{array}{c}\text { EBITDA/ } \\
\text { Interest }\end{array}$ & $\begin{array}{c}\text { Net Debt / } \\
\text { EBITDA }\end{array}$ \\
\hline 2012 & 100 & 165 & 490 & $0.34 x$ & $19.2 x$ & $1.7 x$ \\
\hline 2013 & 147 & 133 & 699 & $0.19 x$ & $22.4 x$ & $1.4 x$ \\
\hline 2014 & 145 & 312 & 751 & $0.18 x$ & $38.0 x$ & $0.9 x$ \\
2015 & 122 & 358 & 1,138 & $0.40 x$ & $36.6 x$ & $2.2 x$ \\
\hline 2016 & 157 & 1,193 & 1,149 & $1.04 x$ & $8.1 x$ & $7.6 x$
\end{tabular}

EBITDA = earnings before interest, taxes, depreciation, and amortization.

Note: Units are in \$ million, unless it's a ratio.

Source: EDL-Generation Public Company. 2017. Presentation Thailand Focus 2017. Investor Relations presentation. Vientiane. http://www.edlgen.com.la/presentations/?lang=en.

Some of EDL's financial issues include the following:

(i) Both domestic sales and exports are not profitable for EDL.

(ii) Power purchase costs per unit have significantly increased after the segregation of EDL-Gen.

(iii) Gross imports were around $28 \%$ of supply over the past 7 years (until 2015), although EDL is now a net exporter and will continue to remain so.

(iv) EDL does not receive the benefit of low-cost financing from international financial institutions and governments, as the Government of the Lao PDR adds an interest charge to EDL lending.

(v) EDL is making heavy loan-funded investments, and debt covenants are severely stretched with EDL facing difficulties to meet debt obligations.

(vi) There has been no equity injection into EDL in the last 7 years.

(vii) EDL has limited financial liquidity and is using short-term liabilities (by retaining trade payables) to invest in capital assets.

(viii) EDL's asset transfers to EDL-Gen do not seem to have positively impacted EDL.

A continuation of a tariff regime that does not reflect underlying costs, combined with the capital-intensive nature of planned generation and transmission infrastructure, indicates that EDL's cumulative losses will invariably grow in the coming years. At a structural level, two options would help alleviate EDL's financial position:

- $\quad$ Balance sheet. As mentioned, there has been no equity injection into EDL since 2011, and a major equity injection would help EDL with its heavy capital expenditure burden although it is only a stop-gap rather than a long-term solution. A debt-to-equity conversion would be an alternative.

- Rationalization of asset transfers. Preliminary information indicates that EDL-Gen received a better deal than EDL on asset transfers for some power plants or shares in IPPs. An independent regulator could assist with ensuring alignment in the prices of future transfers of hydro plants or shares in IPPs from EDL to EDL-Gen. 


\subsubsection{Key Financial Challenges Facing Électricité du Laos}

\section{Lack of Cost-Reflective Tariffs}

The strain on EDL's finances has been the result of many factors, one of which is the low level of electricity tariffs, which have not reflected the cost of procured generation and transmission and distribution investment, for many years. EDL's tariff card subsidizes small residential users (26-150 kWh per month) and the agriculture and irrigation sectors. While this policy subsidizes lower-income households and farmers, this is causing severe pressure on EDL's profits and balance sheet as shown in Table 6 and Table 7.

There is a natural conflict between the need to allow tariffs to rise and the need to attract economic growth into the country, particularly given the looming overcapacity. However, there may be a greater weight being placed on electricity prices in attracting industry than is the case.

In 2015 , about $82 \%$ of domestic consumers paid tariff rates below the cost of electricity (in part due to expensive untargeted subsidies), and revenue collected per $\mathrm{kWh}$ supplied to this sector was $17 \%$ lower than the average unit cost of supply (Figure 24) (footnote 11). EDL realized considerable losses from its sales to the agriculture and residential sectors, which represented $39 \%$ of total electricity consumption in 2015.

Based on the data gathered from power tariffs in 32 cities globally, cost-reflective tariffs tend to result in a higher charge to small residential users and a lower charge to large consumers as illustrated in Figure 25, which is the opposite of the situation in the Lao PDR.

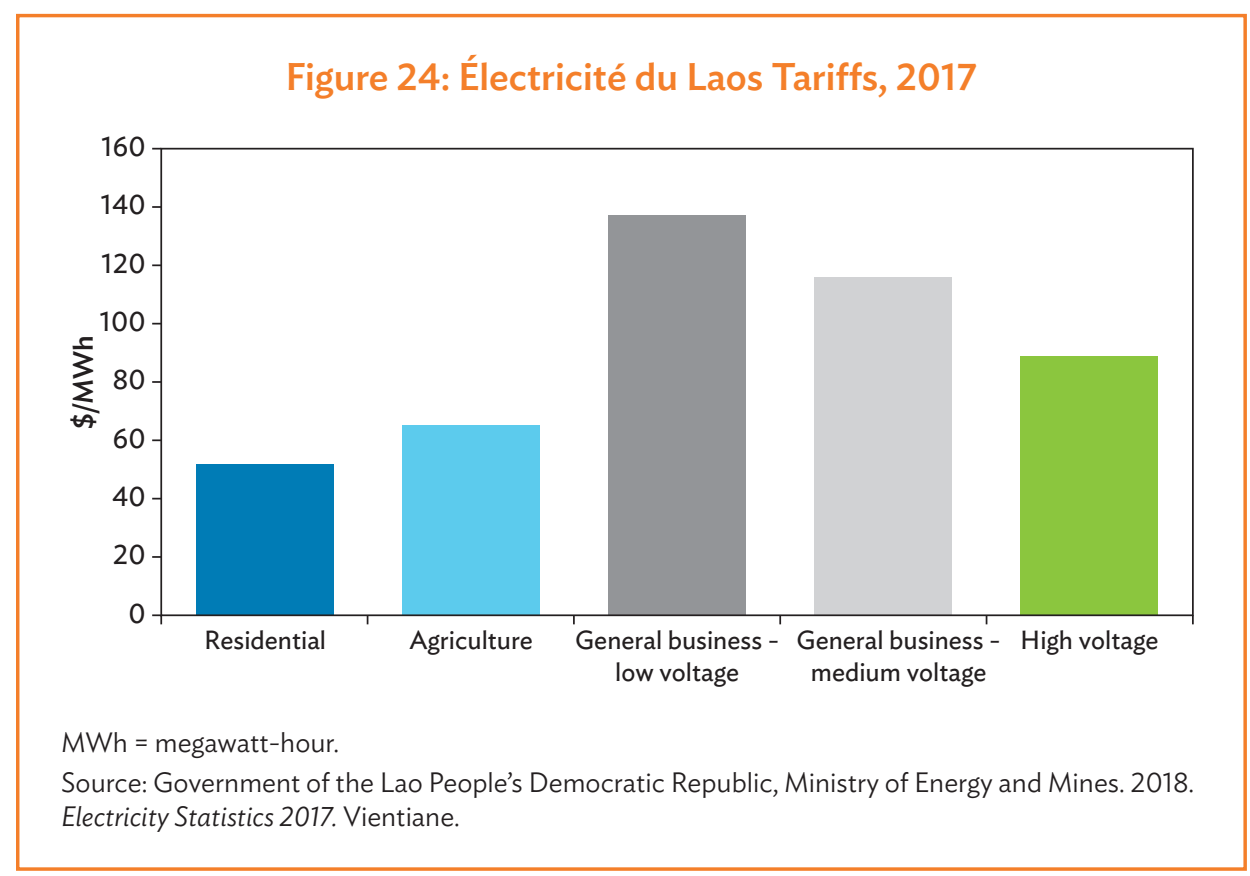




\section{Figure 25: Profile of Global Average Power Tariffs}

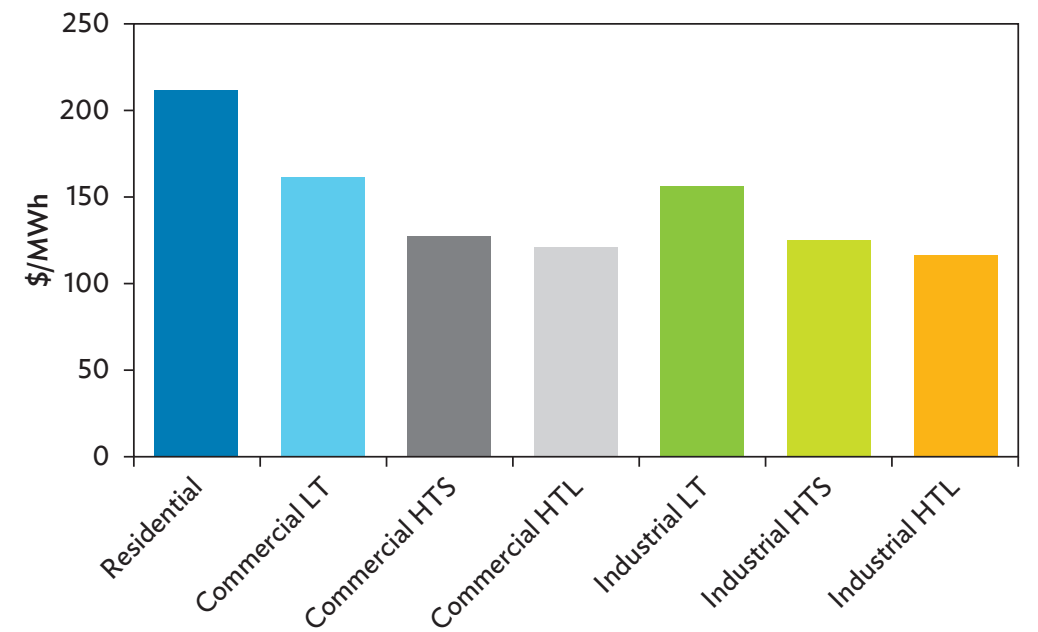

$\mathrm{HTL}=$ high tension large, $\mathrm{HTS}=$ high tension small, $\mathrm{LT}=$ low tension, $\mathrm{MWh}=$ megawatt-hour. Source: Author.

In seeking to raise and/or rationalize tariffs, a change away from a simple system all day flat rate $\mathrm{KN}$ per $\mathrm{kWh}$ tariff (by customer group, consumption, and/or voltage) would be a useful part of restructuring the EDL tariff schedule. There are several options for rationalization of tariffs:

(i) two-part tariffs, with a standing charge to cover fixed costs and an energy charge to cover variable items;

(ii) time-of-day tariffs, with consumers being charged higher amounts for peak power and lower amounts for off-peak power;

(iii) slab size, which could recalibrate the number and size of bands into which customers would fall depending on their consumption; and

(iv) kilovolt-ampere-hour tariffs, which would use the power factors of larger customers and charge a premium for customers with low power factors.

A government policy that subsidizes smaller users with low household incomes is reasonable for a developing nation in some cases. For example, it has been a formal policy in Indonesia since the passing of the Law on State-Owned Enterprises in 2003 for the initial law to be subsequently followed up by various decrees and regulations that refine the method in calculating the amount the government transfers to the state power company each year. In essence, the government covers the difference between the company's revenues and costs and adds on a 7\% markup on costs to provide a positive net margin. The calculation of the public service obligation is subject to strict audits and close checks by various government agencies.

A subsidy policy could be explored in the Lao PDR. The first step would require the government to recognize its policy directive that causes losses for EDL. Second, 
the government should make tariffs cost reflective to the extent possible and, if not, provide financial support to EDL in the form of a public service obligation to keep it solvent. Efforts should also be made to improve low tariff collection rates-particularly to recoup the debts accumulated by agricultural consumers and government agencies - that have exacerbated EDL's weak financial situation.

\section{Financial Liabilities of Électricité du Laos from the Impending Domestic} Power Surplus

Another serious issue relates to the build-out of domestic capacity and generation surplus that is expected in the coming years and that on its present course will see the adjusted reserve margin reach $52.6 \%$ by 2023 . This is a particular concern because, for most of the new IPP- and small power producer-owned plants, EDL entered into PPAs with take-or-pay clauses (without any seasonal or peak/off-peak distinction) whereby failure to purchase the agreed off-take will result in financial penalties (footnote 35). One option would be for EDL to try renegotiating the terms of these contracts with investors, such as by extending the concession period in exchange for a lower levelized tariff. This option could potentially save $2.5 \%-4.0 \%$ of power costs over 5 years, or KN1.4 trillion-KN2.5 trillion, while renegotiating the dividends and/or royalties that $\mathrm{EDL}$ earns from investors is another possibility.

A second potential option would be for EDL to find a market for this power in Thailand or Viet Nam with firm off-take, though this would be contingent on their willingness and ability to buy, as well as to secure an export tariff that recovers the cost of generation from EDL-Gen and the domestic IPPs. It is understood that while Thailand remains the Lao PDR's largest export market, incremental growth in cross-border power trade is likely to be driven by demand from Viet Nam, along with frontier markets such as Malaysia and Singapore, over the longer term. Notwithstanding, any reassignment of domestic generation projects to export markets would invariably require further investment in new transmission infrastructure to make this possible, and the means for EDL to take on more debt to finance such commitments is unclear.

\subsection{Transmission Infrastructure Requirements}

Against the backdrop of EDL's weak financial position, substantial capital expenditure in transmission and distribution infrastructure is needed. Investments in generation by EDL, EDL-Gen, and the private sector have not been matched with a proportionate investment in transmission and distribution infrastructure, and there is a heightened need for the requisite infrastructure to allow excess power to be evacuated. Such a build-out of transmission infrastructure could place further pressure on EDL's finances because the cost of developing transmission infrastructure in the Lao PDR is particularly high. The high cost is due to several factors including (i) low asset utilization rates due to a lack of holistic system planning; (ii) singlesource procurement from engineering, procurement, and construction contractors without any design input from EDL; and (iii) contractors arranging financing that may 
not be the least-cost option. To that end, development partners are in discussions with the government to explore alternative approaches such as a transmission BOT auction, with a view to reducing costs and the debt burden on EDL.

Currently, the capacity of the national transmission grid is insufficient to meet peak demand and match growing domestic generation and demand. When viewed alongside this study's analysis that domestic generation capacity will rise by 3,000 MW from 2,900 MW to 5,900 MW during 2017-2022, it means that significant transmission and distribution investment is required over the next 5 years. All else equal, this would substantially increase EDL's outstanding net debt, but it represents a level of capital expenditure that is far beyond EDL's financial capabilities. Embarking, therefore, on a more reasonable investment program would appear paramount, as would exploring the opportunity for public-private investment partnerships.

From the discussions with the government, it is clear that the looming overcapacity is seen more as an opportunity to export more electricity than as a problem. Further, raising electricity tariffs is seen as a drawback if it deters investment in new industries in the Lao PDR. There may be a greater aspiration to sell exports (and increase domestic demand) than there is demand for exports. Little analysis on the actual export demand (and on the impact of electricity tariff on domestic FDI) seems to have been undertaken, nor is there a cost-benefit analysis of exports given the small tax and royalty gains and the high cost of investment in both power and transmission infrastructure. It is essential that the Lao PDR ensures export-oriented IPPs have firm off-take arrangements and that EDL does not take this risk.

\section{Long-Term Plan for National 500 kV Backbone Transmission}

EDL also has long-term plans to add a $500 \mathrm{kV}$ backbone transmission system to properly connect all regions, especially to connect the north with the other regions (Map 4). The northern region is expected to continue to have substantial net surplus capacity. In addition, the emerging expected surplus capacity in the south will need transmission to allow power to be evacuated to central 2 region particularly.

Investment in transmission infrastructure, such as the $500 \mathrm{kV}$ backbone, is crucial if EDL is to look to export the forthcoming domestic generation surplus. While it is understood that some parts of the $500 \mathrm{kV}$ backbone will be committed to as part of the upcoming PDP, in May 2018 the Lao PDR's National Assembly approved a $\$ 1.66$ billion in loans from the PRC to finance five new transmission lines, of which four are sections of the $500 \mathrm{kV}$ backbone. ${ }^{89}$ The slower pace of transmission buildout is evidently a symptom of the financial constraints that EDL faces, as well as the limitations that below-cost tariff rates have on EDL's investment capabilities for system expansion and integration. Issues such as securing right-of-way access could complicate the build-out of transmission infrastructure and increase cost as a result.

89 Lao PDR National Assembly Standing Committee. 2018. Resolutions of Standing Committee of National Assembly on Approval for Loan Negotiation for Development of 05 Power Transmission-line Projects. Vientiane. 
Map 4: Électricité du Laos Long-Term 500-Kilovolt Transmission Plan

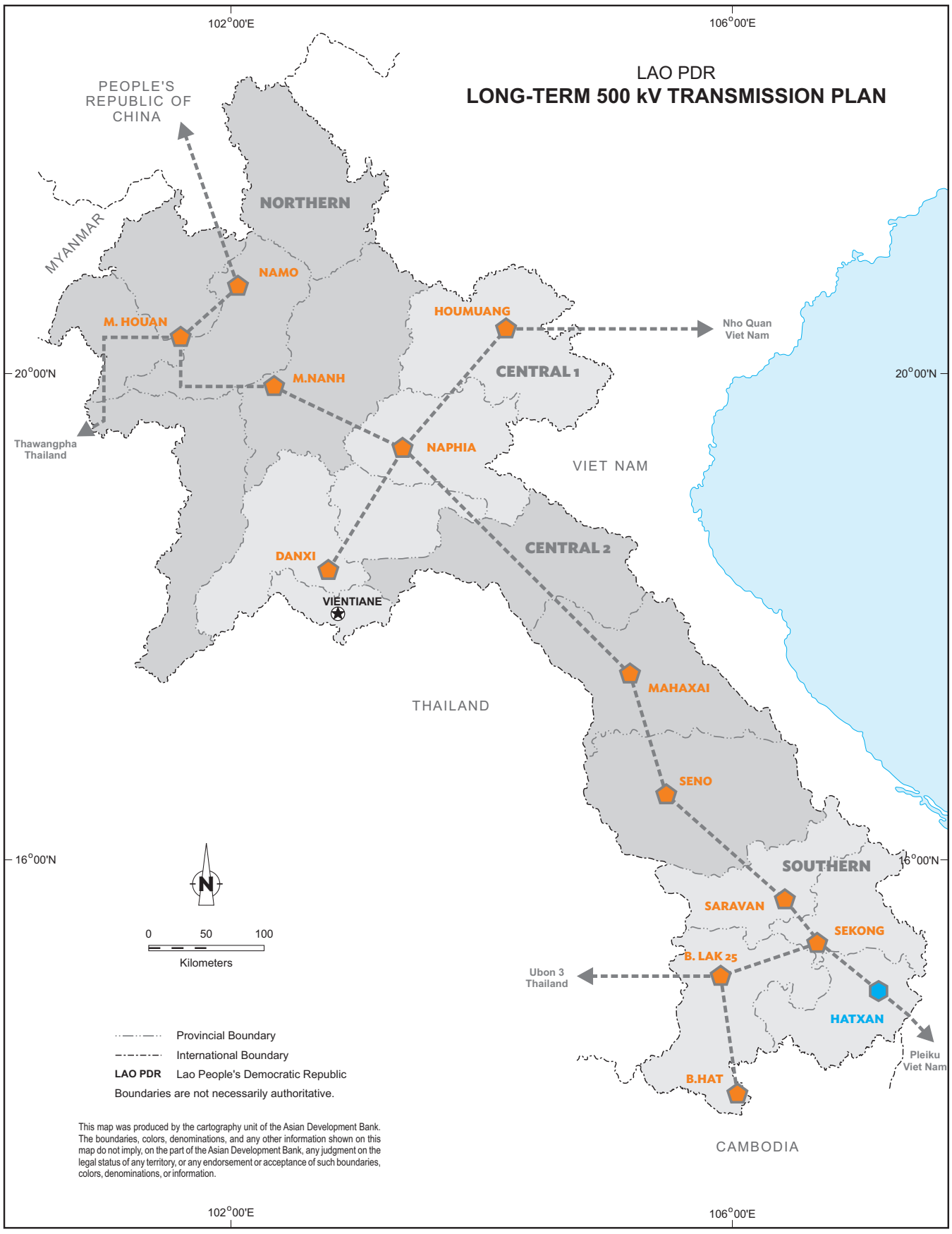

181956D 18LAO ABV

Source: Électricité du Laos. 2016. Country Presentation. Presentation prepared for the 21st Meeting of the Regional Power Trade Coordination Committee. Siem Reap. 8-9 December. 


\section{Analysis of Regional Peak and Capacity Imbalances}

Based on the capacity and demand model used in section 4, the regional imbalances between peak and installed capacity will show some improvement by 2030 (Table 8). A key feature is that the south, which has long been short of power capacity, should have much more capacity available by 2030 . The north remains a major source of surplus power capacity, and this again highlights the need for transmission build-out to transfer power to other regions.

\section{Table 8: Regional Domestic Peak and Domestic Installed Capacity for the Lao People's Democratic Republic, 2017 and 2030}

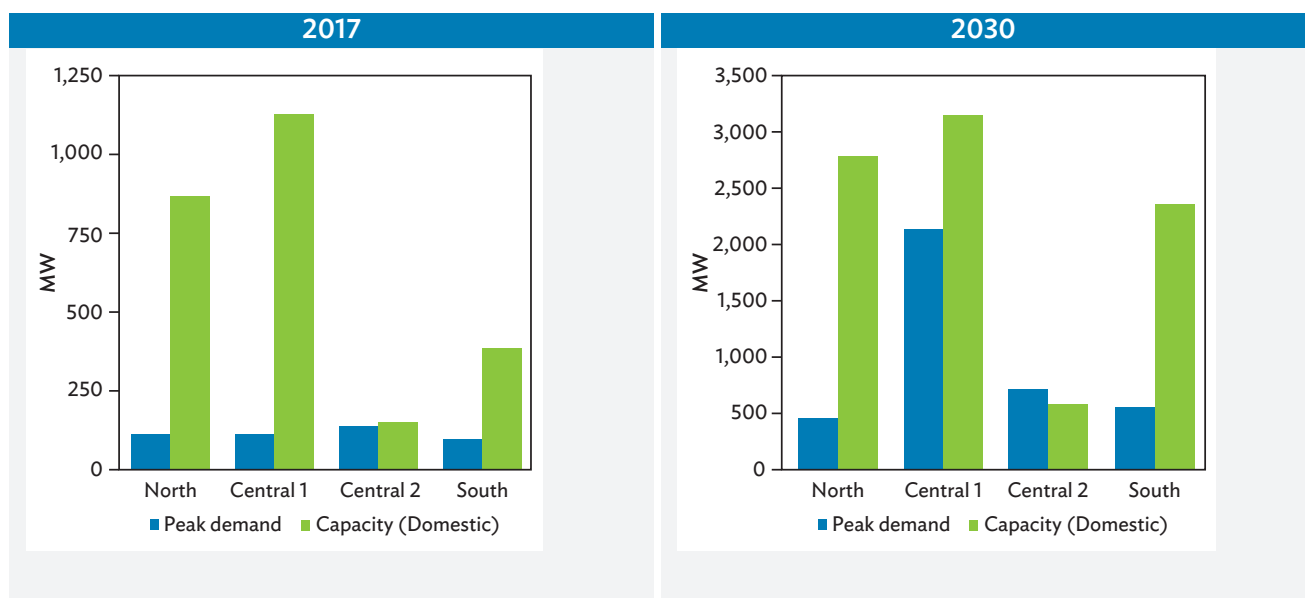

$\mathrm{MW}=$ megawatt

Sources: Tokyo Electric Power Company Holdings, Inc. and Hokuriku Electric Power Company, Inc. 2017. Study on Independent Power Producers (IPPs) in the Lao PDR; Government of the Lao PDR, Ministry of Energy and Mines. 2018. Electricity Statistics 2017. Vientiane; Électricité du Laos. 2016. Country Presentation. Presentation prepared for the 21st Meeting of the Regional Power Trade Coordination Committee. Siem Reap. 8-9 December; and Government of the Lao PDR, Ministry of Energy and Mines. 2016. Power Development Plan 2016-2030. Vientiane.

\section{Foreign Agency Assistance in Power System Planning}

The Japan International Cooperation Agency (JICA) is leading a 25-month study to assist with the development and expansion of the Lao PDR's transmission network. ${ }^{90}$ The expansion of the transmission network is needed to (i) supply high-quality electric power to satisfy domestic power demand and (ii) expand power trade with neighboring countries utilizing abundant hydropower resources. Some constraints that the preliminary JICA study has identified are

- insufficient power network infrastructure to accept huge and growing power supply sources,

- $\quad$ funding required for the power grid extension being several times larger than the current EDL operations, and

- $\quad$ lack of suitable power system operation rules.

90 JICA, Tokyo Electric Power Company Holdings, Inc., TEPCO Power Grid, Inc., NIPPON KOEI Co., Ltd., Tokyo Electric Power Services Co., Ltd. 2017. The Study on Power Network System Master Plan in Lao People's Democratic Republic. Presentation prepared for the kick off meeting. Vientiane. 19 September. 
The aims of the power network system master plan include

- $\quad$ formulating realistic power trade expansion scenario and road map to fulfill the needs of neighboring countries and domestic power demand;

- $\quad$ establishing a new power network system development plan with high reliability and high efficiency, taking into account social and environmental considerations and the desire for greater power exports;

- $\quad$ proposing ways to establish system operation rules that are harmonized with those of neighboring countries; and

- analyzing the financial impact on EDL resulting from the implementation of a power network system development plan and proposing impact mitigation measures.

\subsection{Regulation and the Need for Institutional Capacity Building}

At an institutional level, a key area of concern relates to the lack of capacity and capability of both MEM and EDL to perform their duties effectively, and particularly the bearing this has on their ability to undertake a rigorous and integrated approach to generation and system planning. The effects of this lack of capacity and capability are evident on several fronts:

- $\quad$ The first tranche of the Lao PDR's export-oriented IPPs was successful. IPPs such as Nam Theun 2 and Theun Hinboun 1, in which EDL holds a stake, were contracted at commercially viable tariffs and had dedicated off-take arrangements. While this success was arguably a catalyst for subsequent export-oriented IPP projects, revenues from several of these plants have underperformed because no firm export off-take arrangements are in place. This underperformance has exacerbated EDL's financial predicament given the large loans used to help finance their stakes.

- Another symptom that underscores the need for more robust planning and analysis is tied to the approval of new domestic generation projects and the impending substantial domestic generation surplus, which are set to severely impair EDL's finances given the take-or-pay clauses within many of the associated contracts. Furthermore, there is a lack of contingency regarding the potential to reassign this capacity to export markets, both contractually and insofar as it will require significant build-out of transmission infrastructure to make this possible.

- $\quad$ There are also delays to the PDP, which was expected to be released in early 2018; it remains stalled as of May 2019. The PDP made by EDL's Technical Department must first be financially analyzed and approved, for example, in terms of the ability for EDL to undertake the required investment for any proposed transmission infrastructure. While such an approach is sensible, there is no clarity provided to EDL's Technical Department about the upcoming domestic generation surplus and whether these projects will 
ultimately serve the domestic or export markets. MOUs for cross-border exports, for example, do not provide sufficient certainty and cannot be used as a basis for PDP development and the investment in capital intensive infrastructure-such as the proposed $500 \mathrm{kV}$ backbone- which follows.

- $\quad$ Recognizing these issues, in March 2019, the government announced a moratorium on new power sector investments until 31 December 2020 to allow the government to inspect, assess, and seek markets for projects that have been previously approved and to reformulate the power sector strategy. ${ }^{91}$ Depending on their progress and market potential, projects may be subject to postponement or cancellation. Small and medium-sized renewable energy projects for self-consumption or that already have a market for power supply are exempted. MEM will carry out a study of domestic electricity demand in the Lao PDR and import demand from neighboring countries.

These issues underscore the need to provide support to MEM and EDL, such that the necessary analysis, due process, and capacity building can take place within these institutions and improve their overall financial management. With technical assistance from the World Bank, MEM and EDL developed the Financial Action Plan (footnote 72) that lays out actions for cost optimization, revenue enhancement, and other strategic actions. For example, MEM and EDL have agreed to renegotiate the power purchase price, take-or-pay clause, and payment currency on PPAs with over 30 power generators. The parties have also agreed on a plan to sell or transfer to EDL-Gen some hydropower projects and other generation investments by the end of 2019.

A key piece of the energy landscape that is missing in the Lao PDR is an independent regulator (footnote 11). The paramount mission for a regulator is fairness, i.e., to balance the potentially conflicting interest of all stakeholders. EDL and EDL-Gen are undertaking the following activities that should probably be subject to checks or approval by an independent party such as a regulator:

- approving tariffs including any restructuring of the rate card;

- $\quad$ overseeing any public service obligation payments to EDL;

- $\quad$ subjecting PDPs to independent oversight;92

- reviewing the fairness of asset sales from EDL to EDL-Gen;

- $\quad$ protecting consumers from exploitation by firms with extensive market power;

- $\quad$ safeguarding foreign investors from arbitrary decisions by the single buyer; and

- promoting energy efficiency.

91 Government of the Lao PDR. 2019. Moratorium on Power Investment. Vientiane.

92 In Thailand, the PDP was taken away from EGAT many years ago and receives the inputs of many stakeholders, while in Viet Nam it is overseen by the Institute of Energy under the Ministry of Industry and Trade. 


\subsection{Realizing Hydropower Potential}

General market intelligence indicates investor willingness to accept EDL risk as it is considered a creditworthy off-taker due to implicit or explicit government guarantees on domestic IPPs. EGAT is similarly well regarded.

Contracted power exports could increase from 16 TWh in 2016 to 50 TWh by 2030. PPA sales prices vary by IPP and will likely rise in the future, but, assuming sales price rises from $\$ 35 / M W h$ in 2016 to $\$ 40 / M W h$ in 2030, revenues from exports could rise from $\$ 555$ million in 2016 to $\$ 2$ billion by 2030 , which in turn will help narrow the country's trade deficit.93 While power exports are an important source of revenue for the government's poverty reduction initiatives, an export-oriented policy for the development of hydropower generation projects will face the following challenges:

(i) ensuring that negative social and environmental impacts are properly assessed and minimized;

(ii) balancing domestic consumption needs and export opportunities;

(iii) optimizing trade-offs between short-term benefits (e.g., dividends from equity participation in IPPs) and longer-term benefits (e.g., unified transmission network with interconnection to GMS countries);

(iv) mobilizing and managing financial resources to avoid adverse impact on the economy (e.g., exchange rate effects on agriculture and other exports);

(v) ensuring that development of hydropower projects is consistent with the least-cost expansion planning and done not in an ad hoc basis;

(vi) improving capacity for managing the concession awarding process to ensure that terms and conditions for investors are consistent;

(vii) building capacity for enforcing inspection procedures and monitoring environmental and social safeguards compliance, particularly at the local level; and

(viii) ensuring proper management and tracking of export revenues. ${ }^{94}$

93 United Nations. 2018. UN Comtrade Database. https://comtrade.un.org (2016 data, accessed 12 January 2018).

94 Footnote 11, p. 150. 


\section{Sector Strategy}

\subsection{Government Sector Strategy}

The government's 8th National Socio-Economic Development Plan (NSEDP), covering 2016-2020, targets the Lao PDR's eligibility for graduation from least-developed country status by 2020 , as well as sustainable economic, social, and environmental development. ${ }^{95}$ Recognizing that expanded access to modern and affordable forms of energy and better utilization of current energy resources is essential for the Lao PDR's continued social and economic advancement, the 8th NSEDP prioritizes the need to develop the energy sector in an affordable, inclusive, and sustainable manner. In the Energy Policy 2015, the government laid out the following targets for the power sector: (i) provide affordable, reliable, and sustainable electricity supply to the population; (ii) achieve an electrification rate of more than $90 \%$ by 2020 ; (iii) improve and expand transmission networks to facilitate power exchange with ASEAN countries; (iv) develop the country's hydropower potential with private investor participation; and ( $v$ ) expand renewable energy to account for $30 \%$ of the power mix under a reasonable feed-in tariff scheme. EDL's Power Development Plan (PDP) 2010-2020 lays out investment requirements for generation, transmission, and distribution to meet national objectives. ${ }^{96}$

Having achieved $92 \%$ electrification of households in 2016 , the government is now targeting $95 \%$ electrification by 2020 and has made the development of basic infrastructure, including the extension of power distribution lines, in the northern provinces a priority. The government is also refocusing its attention on exporting a greater amount of electricity to its neighboring countries, particularly under its long-standing export agreements with Thailand and Viet Nam. ${ }^{97}$ The government has recently initiated a study in collaboration with the Japan International Cooperation Agency (JICA) to prepare a power network system master plan that would help it realize its plans to increase export of electricity. A near-term export market is Shan State in Myanmar, which is well-placed to receive surplus generation from the north of the Lao PDR.

95 Government of the Lao PDR, Ministry of Planning and Investment. 2016. 8th Five-Year National Socio-Economic Development Plan (2016-2020). Vientiane.

96 Footnote 11, p. 133.

97 Most recently, MOUs were signed in 2016, under which the Lao PDR could export 9,000 MW of hydropower to Thailand and 5,000 MW to Viet Nam in the next 10-15 years. 


\subsection{ADB Sector Support Program and Experience}

ADB has played a long-standing role in providing financial support and technical assistance to the Lao PDR energy sector, as early as May 1971 with the development of the Vientiane power distribution network. Assistance in the sector has primarily focused on increasing generation capacity, particularly hydropower, in an environmentally and socially sustainable manner; expanding transmission and distribution networks into poor rural areas; and enhancing the capacity of EDL's staff in technical and procurement matters. Since 1971, ADB has awarded 25 loans and 29 technical assistance programs to the Lao PDR energy sector, totaling $\$ 840$ million. Projects approved since 2005 are highlighted in Table 9.

As part of its ongoing sector support, $A D B$, with cofinancing from the Export-Import Bank of Korea, is currently implementing the Greater Mekong Subregion (GMS) Northern Power Transmission Project. ${ }^{98}$ The project supports the government to

Table 9: ADB Loan and Technical Assistance Support to the Power Sector in the Lao People's Democratic Republic, since 2005

\begin{tabular}{llc} 
Project & Date Approved & $\begin{array}{c}\text { Committed } \\
\text { (in \$) }\end{array}$ \\
\hline Technical Assistance & & \\
\hline GMS Northern Power Transmission Project & July 2006 & 800,000 \\
$\begin{array}{l}\text { Cumulative Impact Assessment for the Nam Ngum 3 } \\
\text { Hydropower Project }\end{array}$ & February 2007 & 983,000 \\
Na Bong-Udon Thani Power Transmission Project & December 2007 & 760,000 \\
$\begin{array}{l}\text { GMS Nam Theun 2 Hydroelectric Project - Social } \\
\text { Safeguards Monitoring }\end{array}$ & July 2008 & 400,000 \\
\hline Small and Mini Hydroelectric Development Project & January 2009 & $1,000,000$ \\
$\begin{array}{l}\text { Renewable Energy Development in Remote } \\
\text { Communities Project }\end{array}$ & September 2011 & $1,000,000$ \\
Loan & & ADB loan: \\
Nam Ngiep 1 Hydropower Project (PSOD) & July 2014 & ADB loan: \\
& & $71,700,000$
\end{tabular}

ADB = Asian Development Bank, GMS = Greater Mekong Subregion, Lao PDR = Lao People's Democratic Republic, PSOD = Private Sector Operations Department.

Source: ADB. List of ADB Loans and Technical Assistance Programs since 1970.

98 ADB. 2009. Report and Recommendation of the President to the Board of Directors: Proposed Asian Development Fund Grant to the Lao People's Democratic Republic for the Greater Mekong Subregion Northern Power Transmission Project. Manila. 
construct transmission lines and associated substations to (i) expand access to grid electricity to consumers in Xayabuli, Phongsaly, and Vientiane provinces; and (ii) increase power trade with Thailand. The project is currently on track for the commissioning of the transmission and distribution systems by June 2019 and provides significant lessons for the management of future projects. With regional sector support, ADB has helped promote the development of a GMS power market through the Regional Power Trade Coordination Committee (RPTCC). ${ }^{99}$

\subsection{ADB Self-Evaluation}

The country partnership strategy (CSP) final review undertaken in 2016 reflects the most recent independent evaluation of ADB's performance in the Lao PDR's energy sector, as well as its role in supporting the country more broadly. The review concluded that ADB's performance was satisfactory because of an effective local mission by taking "a leading role in policy dialogue within the government's aid management framework" and by satisfactorily supervising project implementation. ${ }^{100}$ The report rated ADB's overall performance in the Lao PDR successful, while noting that ADB's performance in the project completion reports ranged from highly satisfactory to satisfactory.

\subsection{ADB Lessons Learned}

ADB's CPS 2017-2020, which sets out the principles for ADB's assistance and support to the Lao PDR, makes several high-level recommendations based on lessons from its 2012-2016 strategy. These recommendations include (i) enhancing work with the private sector to promote inclusive growth; (ii) continuing to support the development of human capital; and (ii) boosting the growth of micro, small, and medium-sized enterprises and their integration across the ASEAN Economic Community (footnote 100). At a more operational level, the need for improved coordination between ADB divisions and other development partners is highlighted as an area where improvements could be made by improving synergies among operations, and adopting more systematic approaches in areas such as knowledge management.

While the review rated ADB's overall performance in the Lao PDR successful, not every project it has undertaken in the country has had the intended outcomes; differing project outcomes invariably mean that lessons can be learned. One notable example is the Renewable Energy Development in Remote Communities Project, which sought to provide technical assistance that would see $5.5 \mathrm{MW}$ of renewable energy resources improving electrification in remote areas of Oudomxay, Luang Namtha, and Phongsaly. The project, approved in 2011, ultimately failed as a result of

99 ADB. 2011. The Greater Mekong Subregion Economic Cooperation Program Strategic Framework 2012-2022. Manila.

100 Independent Evaluation Department. 2016. Lao People's Democratic Republic: Country Partnership Strategy Final Review Validation, 2012-2016. Manila: ADB. 
an overly rigid financing framework that offered only loan - and not grant-funding to the Ministry of Energy and Mines (MEM) due to the country's debt distress rating at the time. ${ }^{101}$ MEM was not prepared to receive financing that did not include a significant portion of grant aid for a renewable project that was not financially viable on its own economic merits, and an overly short project implementation window weakened ADB's ability to reevaluate its approach. While these points of failure contributed to the project not achieving its envisaged outcomes, they do still underscore the challenges-both financially and operationally-in helping the Lao PDR achieve its remaining electrification objectives.

Affordable electricity tariffs are critical to achieving the government's goals of rural electrification and 95\% electricity access. However, as current tariffs are below cost recovery levels, EDL should focus on measures to reduce the cost of supply, including reducing technical and nontechnical transmission and distribution losses, more strictly managing accounts receivable, implementing demand-side management measures, and extending credit for payment of service connection costs (footnote 22), while executing its policy on gradually increasing tariffs at $2 \%$ annually. At the same time, the government plans to electrify the remaining households with grid extension; however, this strategy may not be economically viable, as previously mentioned, because the marginal cost to electrify the final $8 \%$ of households is estimated to be more than double the cost of electrifying the previous $15 \%-20 \%$ of households. Therefore, the government may want to explore a combination of on-grid and offgrid alternatives, including renewables-based mini-grids and battery storage through a least-cost planning approach. Given the Lao PDR's large solar endowment and recent reductions in the cost of renewables-based electricity, especially for solar, the Lao PDR may be well-served with off-grid renewables to meet a large portion of its rural electrification needs. Further, this would contribute to the country's national renewable energy targets.

\subsection{Other Development Partner Support}

Alongside $A D B$, several development partners are active in the energy sector in the Lao PDR, notably JICA, Agence Française de Développement (AFD), the United States Agency for International Development (USAID), and the World Bank, highlighting the need for close cooperation given the interrelated nature of many of the issues the Lao PDR power sector is facing.

JICA has been a long-standing donor and plays a particularly active role in the sector; focus areas of assistance have included planning and feasibility studies of hydropower projects, and technical and investment support for power transmission and distribution infrastructure such as the Southern Region Power System Development Project, which was completed in 2016. Currently, JICA is assisting the Lao PDR with a $40 \mathrm{MW}$ expansion of the Nam Ngum 1 hydropower project, the capacity of which is expected to rise to $195 \mathrm{MW}$ by 2020 (though it is understood that it will be

101 ADB. 2015. Technical Assistance Completion Report: Renewable Energy Development in Remote Communities Project. Manila. 
delayed). ${ }^{102}$ Since September 2017, JICA has also been providing technical assistance to MEM's Department of Energy Policy and Planning and EDL on workstreams to support the development of a power system master plan and improve the capacity and resilience of the Lao PDR's transmission grid.

AFD has provided support for the development of the Nam Theun 2 hydropower project via a nonsovereign loan to Lao Holding State Enterprise (LHSE) and a government grant, and has recently initiated a technical assistance program to complement resettlement and alternative livelihood activities relating to the project. ${ }^{103} \mathrm{AFD}$ is also currently considering providing nonsovereign loans of up to $€ 50$ million to promote the deployment of new renewable technologies. Potential initiatives include a direct loan to EDL-Gen and EDL-Gen Solar to deploy 3-15 MW of solar PV, as well as a credit line to local banks to help finance small-scale renewable projects, particularly small hydropower.

The World Bank has played a central role in electrification initiatives through a commitment of $\$ 10$ million toward Phase 1 of the Rural Electrification Project ${ }^{104}$ in 2006 , followed by a further $\$ 20$ million toward Phase 2 in $2010 .{ }^{105}$ In 2005 , the World Bank committed $\$ 20$ million in grant financing ${ }^{106}$ toward the development of Nam Theun 2, an export-oriented hydropower project, and has also provided technical assistance focusing on tariff reform and electricity loss reduction. More recently, the World Bank has provided technical assistance to MEM to allow them to get advice in their review of the financial situation of the power sector, with tariff design as one key aspect (footnote 72). The World Bank is also assisting EDL with a distribution loss reduction plan, in recognition of the need for automation.

In partnership with ADB, USAID's Clean Power Asia program is undertaking renewable energy-focused technical assistance work in the Lao PDR. In particular, USAID is developing a capacity-building plan for integrating renewable energy, energy efficiency, and climate resilience into the power development planning process and is assisting MEM to design a solar pilot auction.

\subsection{ADB Sector Forward Strategy}

Under the CPS 2017-2020, ADB operations will focus on (i) improving physical connectivity to catalyze private sector investment in the economy to generate employment and income, (ii) developing skills that support growth in the nonresource sectors and improving access to health services to enhance labor productivity, and (iii) ensuring sustainable natural resource management and climate

\footnotetext{
JICA email message to ADB, 19 February 2018.

AFD interview with ADB, 28 February 2018.

Included is the Village Off-Grid Promotion and Support program that saw the installation of 25,000 SHS.

105 World Bank. Projects \& Operations. http://projects.worldbank.org/search?lang=en\&searchTerm=\&countryco de_exact=LA (accessed 2 March 2018).

106 The World Bank's financing package also included an International Development Association partial risk guarantee and Multilateral Investment Guarantee Agency political risk insurance guarantees on debt and equity.
} 
resilience. ${ }^{107}$ Gender equity and governance are crosscutting themes. The energy sector directly supports outcomes under priority (i) above, including supporting regional cooperation and integration through improved rural electrification and increased energy trade as well as the promotion of renewable energy and energy efficiency. The CPS will flexibly respond to government priorities as they evolve. The CPS priorities are aligned with the 8th NSEDP and will help the Lao PDR achieve its commitments to the United Nations Sustainable Development Goals and Nationally Determined Contributions. The CPS also incorporates lessons learned from past ADB operations.

\subsection{Lending and Non-Lending Program and Resource Needs}

In support of the first strategic pillar of the CPS 2017-2020, ADB's public and private sector operations will complement the government's initiatives to (i) complete the electrification agenda, (ii) expand the national transmission and distribution network with cross-border interconnections, and (iii) develop large hydropower and renewable energy sources in an environmentally and socially sustainable manner. The GMS Economic Cooperation Program ${ }^{108}$ will continue to be a key platform from which ADB will deliver support. ADB will also support the expansion of on-grid and off-grid distribution, particularly in border areas. ADB's Private Sector Operations Department will continue to look for opportunities in the generation and transmission sectors, and the Office of Public-Private Partnership will explore the feasibility of supporting investments in transmission. The program will include both lending and non-lending products as detailed in the sector results framework.

\subsubsection{Lending Products}

\section{Distribution Expansion}

ADB plans to continue funding investments in cross-border power trade and new grid expansion projects. An investment project, the Rural Power Distribution and Efficiency Improvement Project, scheduled for 2019 as standby, aims to (i) expand distribution networks in the provinces of Phongsaly, Huaphanh, and Xieng Khuang; and (ii) provide at least 3,640 household connections. Project preparatory activities for this project were initiated in April 2018.

\section{Large Hydropower and Renewables}

ADB will continue to monitor the development of renewable energy generation in the Lao PDR and explore possibilities for supporting investments in renewablebased mini-grids, battery storage, and floating solar. ADB's Private Sector Operations

107 ADB. 2017. Country Partnership Strategy: Lao People's Democratic Republic, 2017-2020-More Inclusive and Sustainable Economic Growth. Manila.

108 ADB. 2014. Harmonizing the Greater Mekong Subregion Power Systems to Facilitate Regional Power Trade. Manila (RETA 8830); and ADB. 2015. Technical Assistance for Integrated Resource Planning with Strategic Environmental Assessment for Sustainable Power Sector Development in the Greater Mekong Subregion. Manila (RETA 9003). 
Department will continue to seek investment opportunities in sustainable hydropower generation and other renewable sources.

\subsubsection{Non-Lending Products}

\section{Regional Cooperation and Power Trade}

Energy cooperation, a major pillar of the wider GMS Economic Cooperation Program, is motivated by rapid growth in demand and concerns about energy security throughout the GMS and is facilitated by the RPTCC. Established in 2002, the RPTCC focuses on strengthening regional transmission networks, promoting cross-border investments in energy resources, and developing a regional electricity market in a phased manner. Regional electricity trade can make use of the diverse regional energy resources and power supply in meeting varying demand profiles and contribute to improved reliability, lower costs, and reduced emission levels across the subregion. ADB strongly supports regional power trade as an important element of its policy to emphasize regional economic cooperation.

In the Lao PDR, ADB will assist the government to explore options for additional electricity export due to excess domestic hydropower generation. Under the GMS Economic Cooperation Program (footnote 108), a technical assistance activity for $\$ 1.5$ million has been approved to support feasibility studies for priority interconnection projects, including a Lao PDR-Myanmar connection (Luang Namtha-Shan State) and Northern Lao PDR-Viet Nam connection (Xam NeuaNho Quan).

\section{Capacity Building and Institutional Reform}

ADB and the World Bank provide technical support to the RPTCC and its two working groups: the Working Group on Regulatory Issues and the Working Group on Performance Standards and Grid Code (footnote 108). The Working Group on Regulatory Issues is in the process of harmonizing regulations regarding open (third-party) access to transmission systems, developing a framework for calculating wheeling charges for use of common transmission facilities, and creating a standard template for long-term power purchase agreements (PPAs). The Working Group on Performance Standards and Grid Code has developed common performance standards and is currently preparing a regional grid code.

\subsection{Risks and Assumptions}

The fundamental assumption for ADB's proposed strategy of support for the energy sector is that the government will implement the 8th NSEDP, 2016-2020, which includes targets for the provision of reliable and sustainable energy for domestic and export markets. The government's Energy Policy 2015 and PDP for 2010-2020 serve as the basis for ADB's energy strategy for the Lao PDR.

Mobilizing financing, particularly for the build-out of transmission infrastructure for power export, is a key challenge the government must overcome if it wishes to meet 
the targets for the energy sector. ADB and other development partners can help by leveraging both public and private sector funding.

ADB's proposed strategy of support for the Lao PDR energy sector is subject to three main risks. First, the Lao PDR has a limited capacity to plan for, evaluate, and manage energy projects. Well-trained staff are required to identify and appraise potential projects; assess financial, social, and environmental impacts; and implement and manage projects. Second, the rising interest of private developers in projects in the Lao PDR may increase the risk that unsolicited or even unnecessary projects are accepted without considering financial implications or mitigating the environmental and social impacts. Finally, delays in securing IPPs and/or off-take arrangements from neighboring countries would severely impact the government's export target. For ADB's program, this would affect support for high-voltage transmission interconnection projects.

The proposed ADB strategy in support of the Lao PDR energy sector includes risk mitigation. Capacity building for MEM, EDL, and Ministry of Natural Resources and Environment staff will be integrated into ADB projects and programs. With appropriate training, the staff of the MEM and EDL will be better able to evaluate the technical, financial, and economic feasibility of project proposals. Well-trained and experienced staff will also be able to properly prioritize power projects and ensure that project developers apply best practice in meeting the standards of ADB's social and environmental safeguards. The third risk will be mitigated through greater support to project readiness. ADB's strategy includes support in partnership with both the public sector (for transmission network projects) and the private sector (for hydropower projects).

In summary, the proposed ADB strategy in support of the Lao PDR energy sector is based on the needs of the country, as identified by the government. While there are some risks associated with the implementation of the strategy, appropriate risk mitigation measures have been incorporated. 


\section{Sector Road Map and Results Framework, 2018-2023}

\begin{tabular}{|c|c|c|c|c|c|}
\hline \multicolumn{2}{|c|}{ Country Sector Outcomes } & \multicolumn{2}{|c|}{ Country Sector Outputs } & \multicolumn{2}{|c|}{ ADB Sector Operations } \\
\hline $\begin{array}{c}\text { Sector Outcomes } \\
\text { with ADB } \\
\text { Contribution }\end{array}$ & $\begin{array}{l}\text { Indicators with } \\
\text { Targets and } \\
\text { Baselines }\end{array}$ & $\begin{array}{l}\text { Sector Outputs with } \\
\text { ADB Contribution }\end{array}$ & $\begin{array}{c}\text { Indicators with } \\
\text { Incremental Targets }\end{array}$ & $\begin{array}{l}\text { Planned and } \\
\text { Ongoing ADB } \\
\text { Interventions }\end{array}$ & $\begin{array}{c}\text { Main Outputs } \\
\text { Expected from ADB } \\
\text { Interventions }\end{array}$ \\
\hline \multirow{14}{*}{$\begin{array}{l}\text { Increased } \\
\text { grid-electricity } \\
\text { consumption } \\
\text { and cross-border } \\
\text { electricity trade } \\
\text { Improved } \\
\text { connectivity } \\
\text { of physical } \\
\text { infrastructure } \\
\text { Enhanced } \\
\text { institutional, } \\
\text { regulatory, and } \\
\text { human resource } \\
\text { capacity to provide } \\
\text { reliable and } \\
\text { sustainable energy/ } \\
\text { electricity supply }\end{array}$} & \multirow{3}{*}{$\begin{array}{l}\text { Power demand } \\
\text { increases to } 2,000 \\
\text { MW by } 2023(2017 \\
\text { baseline: } 928 \mathrm{MW})\end{array}$} & \multirow{4}{*}{$\begin{array}{l}\text { Electricity } \\
\text { transmission } \\
\text { and distribution } \\
\text { system expanded, } \\
\text { improved, and well } \\
\text { managed }\end{array}$} & \multirow{4}{*}{$\begin{array}{l}920 \mathrm{~km} \text { of } \\
\text { additional HV } \\
\text { transmission } \\
\text { lines constructed } \\
\text { by } 2023(2017 \\
\text { baseline: } 8,753 \mathrm{~km})\end{array}$} & \multirow{2}{*}{$\begin{array}{l}\text { Planned key } \\
\text { activity areas }\end{array}$} & \multirow{5}{*}{$\begin{array}{l}\text { Pipeline projects } \\
\text { About } 120 \mathrm{~km} \text { of } \\
\text { distribution lines } \\
\text { in Phongsaly, } \\
\text { Huaphanh, and } \\
\text { Xieng Khuang } \\
\text { constructed }\end{array}$} \\
\hline & & & & & \\
\hline & & & & \multirow{4}{*}{$\begin{array}{l}\text { Transmission } \\
\text { and distribution } \\
\text { network expansion, } \\
\text { including HV } \\
\text { lines for domestic } \\
\text { connections and } \\
\text { international power } \\
\text { trade }\end{array}$} & \\
\hline & \multirow{11}{*}{$\begin{array}{l}\text { Electricity exports } \\
\text { increased to } \\
30.0 \text { TWh/year by } \\
2023 \\
\text { ( } 2017 \text { baseline: } \\
24.9 \text { TWh/year) } \\
\text { Household } \\
\text { electrification rate } \\
\text { increases to } 95 \% \\
\text { in } 2020 \text { (2017 } \\
\text { baseline: } 92 \%)\end{array}$} & & & & \\
\hline & & \multirow{10}{*}{$\begin{array}{l}\text { Institutions and } \\
\text { institutional } \\
\text { capacity } \\
\text { established for } \\
\text { renewable energy } \\
\text { and energy } \\
\text { efficiency } \\
\text { Increased use of } \\
\text { renewable energy } \\
\text { and practice of } \\
\text { energy efficiency }\end{array}$} & \multirow{4}{*}{$\begin{array}{l}500 \mathrm{~km} \text { of } \\
\text { additional MV } \\
\text { sub-transmission } \\
\text { lines constructed } \\
\text { by } 2023 \\
(2017 \text { baseline: } \\
30,720 \mathrm{~km})\end{array}$} & & \\
\hline & & & & & $\begin{array}{l}\text { Electrify at least } \\
3,640 \text { households }\end{array}$ \\
\hline & & & & Development of a & Ongoing projects \\
\hline & & & & & Electrify up to \\
\hline & & & $\begin{array}{l}500 \mathrm{~km} \text { of } \\
\text { additional } \\
\text { LV distribution }\end{array}$ & $\begin{array}{l}\text { for energy } \\
\text { efficiency and } \\
\text { conservation }\end{array}$ & $\begin{array}{l}\text { and provide no- } \\
\text { interest credit to } \\
8,600 \text { households }\end{array}$ \\
\hline & & & $\begin{array}{l}\text { lines constructed } \\
\text { by } 2023 \\
\text { ( } 2017 \text { baseline: } \\
19,279 \mathrm{~km})\end{array}$ & $\begin{array}{l}\text { Pipeline projects } \\
\text { with estimated } \\
\text { amounts }\end{array}$ & $\begin{array}{l}398 \mathrm{~km} \text { of } 115 \mathrm{kV} \\
\text { transmission lines } \\
\text { with associated } \\
115 \mathrm{kV} \text {-to- } 22 \mathrm{kV}\end{array}$ \\
\hline & & & & $\begin{array}{l}\text { Rural Power } \\
\text { Distribution } \\
\text { and Efficiency } \\
\text { Improvement } \\
\text { Project (2019: }\end{array}$ & $\begin{array}{l}\text { substations, and } \\
1,100 \mathrm{~km} \text { of } 22 \mathrm{kV} \\
\text { distribution lines to } \\
\text { expand the grid in } \\
\text { three provinces }\end{array}$ \\
\hline & & & & $\begin{array}{l}\$ 30 \text { million OCR) } \\
\text { Ongoing projects }\end{array}$ & $\begin{array}{l}\text { Capacity building } \\
\text { for EDL and MEM }\end{array}$ \\
\hline & & & & $\begin{array}{l}\text { with approved } \\
\text { amounts }\end{array}$ & $\begin{array}{l}\text { National policy on } \\
\text { energy efficiency }\end{array}$ \\
\hline & & & & $\begin{array}{l}\text { GMS Northern } \\
\text { Power Transmission } \\
\text { Project }(\$ 20 \text { million } \\
\text { and } \$ 37.9 \text { million } \\
\text { cofinancing) }\end{array}$ & conservation \\
\hline
\end{tabular}

$\mathrm{ADB}=$ Asian Development Bank, $\mathrm{EDL}=$ Électricité du Laos, GMS = Greater Mekong Subregion, HV = high-voltage, $\mathrm{km}=$ kilometer, $\mathrm{kV}=\mathrm{kilovolt}$, Lao PDR = Lao People's Democratic Republic, LV = low-voltage, MEM = Ministry of Energy and Mines, MV = medium-voltage, $M W=$ megawatt, $\mathrm{MWh}=$ megawatt-hour, $\mathrm{OCR}=$ ordinary capital resources, $\mathrm{TWh}=$ terawatt-hour.

Source: ADB. 


\section{Appendix 1}

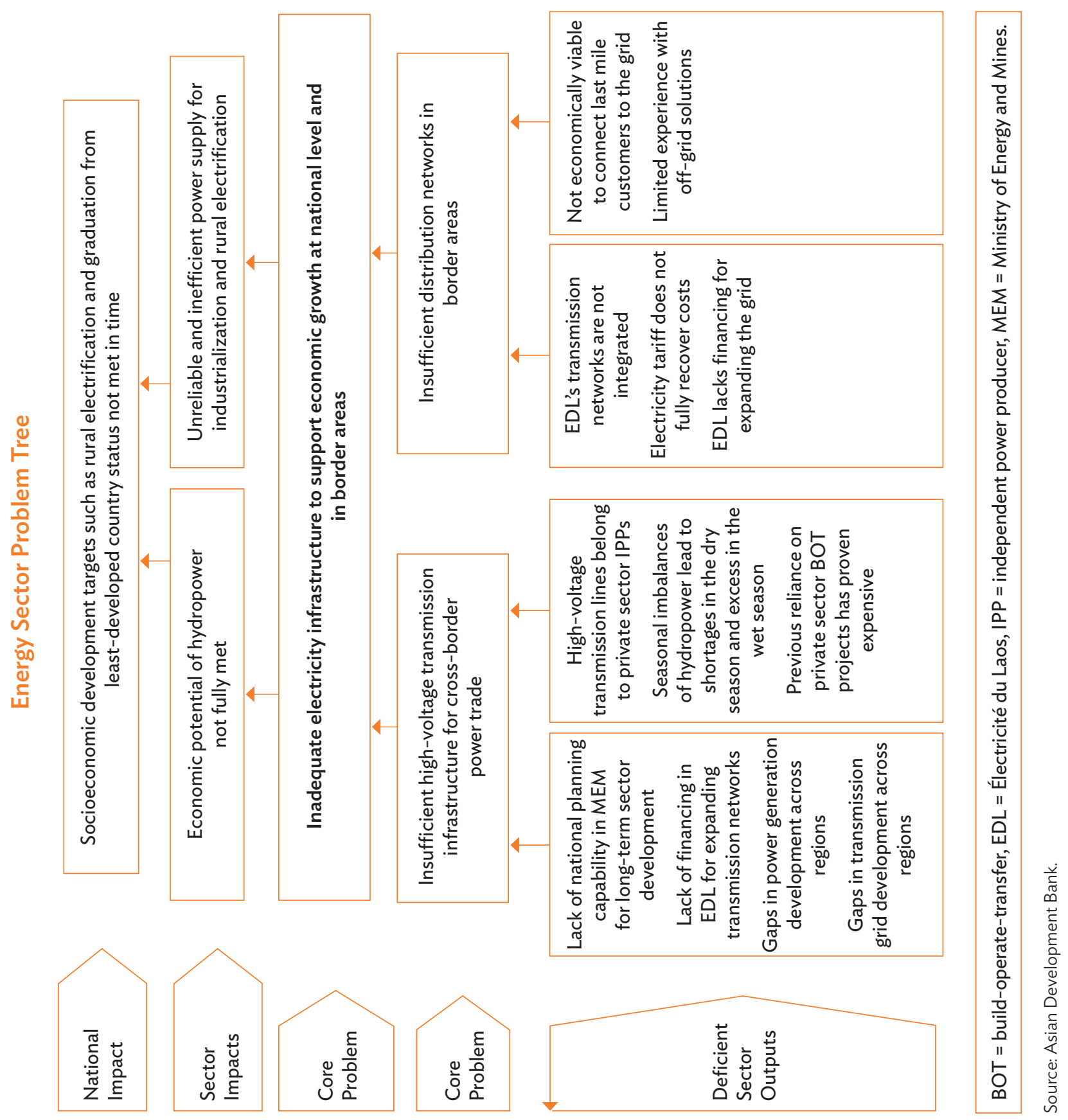




\section{Appendix 2}

Power Plants of the Lao People's Democratic Republic, as of 2017

\begin{tabular}{|c|c|c|c|c|c|c|}
\hline \multirow[b]{2}{*}{ Plant Name } & \multirow[b]{2}{*}{ Region } & \multirow[b]{2}{*}{ Fuel } & \multicolumn{3}{|c|}{$\begin{array}{c}\text { Capacity } \\
(\mathrm{MW})\end{array}$} & \multirow[b]{2}{*}{ COD } \\
\hline & & & Total & Domestic & Export & \\
\hline Nam Dong & North & Hydro & 1.0 & 1.0 & & 1970 \\
\hline Nam Ko & North & Hydro & 1.5 & 1.5 & & 1996 \\
\hline Nam Boun 1 & North & Hydro & 0.1 & 0.1 & & 1996 \\
\hline Nam Mong & North & Hydro & 0.1 & 0.1 & & 1996 \\
\hline Nam Ngay & North & Hydro & 1.2 & 1.2 & & 2001 \\
\hline Nam Nhone & North & Hydro & 3.0 & 3.0 & & 2011 \\
\hline Nam Tha 3 & North & Hydro & 1.3 & 1.3 & & 2011 \\
\hline Houay Ngou & North & Hydro & 0.0 & 0.0 & & 2011 \\
\hline Nam Sae & North & Hydro & 0.1 & 0.1 & & 2012 \\
\hline Nam Long & North & Hydro & 5.5 & 5.5 & & 2013 \\
\hline Hongsa Lignite & North & Lignite & $1,878.0$ & 100.0 & $1,778.0$ & 2015-2016 \\
\hline Nam Karn 2 & North & Hydro & 130.0 & 130.0 & & 2015 \\
\hline Nam Ou 9 & North & Hydro & 0.5 & 0.5 & & 2015 \\
\hline Nam Ou 2 & North & Hydro & 120.0 & 120.0 & & 2016 \\
\hline Nam Beng & North & Hydro & 36.0 & 36.0 & & 2016 \\
\hline Nam Ou 5 & North & Hydro & 240.0 & 240.0 & & 2016 \\
\hline Nam Ou 6 & North & Hydro & 180.0 & 180.0 & & 2016 \\
\hline Nam Karn 3 & North & Hydro & 60.0 & 60.0 & & 2016 \\
\hline Nam Peun 2 & North & Hydro & 12.0 & 12.0 & & 2017 \\
\hline \multirow[t]{2}{*}{ Nam Nga 2} & North & Hydro & 14.5 & 14.5 & & 2017 \\
\hline & & North & $2,684.7$ & 906.7 & $1,778.0$ & \\
\hline Nam Ngum 1 & Central 1 & Hydro & 155.0 & 155.0 & & 1971 \\
\hline Nam San & Central 1 & Hydro & 0.1 & 0.1 & & 1995 \\
\hline Nam Et & Central 1 & Hydro & 0.1 & 0.1 & & 1995 \\
\hline Nam Sat & Central 1 & Hydro & 0.3 & 0.3 & & 1999 \\
\hline Nam Leuk & Central 1 & Hydro & 60.0 & 60.0 & & 2000 \\
\hline Nam Mang 3 & Central 1 & Hydro & 40.0 & 40.0 & & 2005 \\
\hline Nam Lik 1/2 & Central 1 & Hydro & 100.0 & 100.0 & & 2010 \\
\hline Nam Ngum 2 & Central 1 & Hydro & 615.0 & & 615.0 & 2012 \\
\hline Nam Song & Central 1 & Hydro & 6.0 & 6.0 & & 2012 \\
\hline Nam Ngum 5 & Central 1 & Hydro & 120.0 & 120.0 & & 2012 \\
\hline
\end{tabular}


continued

\begin{tabular}{|c|c|c|c|c|c|c|}
\hline \multirow[b]{2}{*}{ Plant Name } & \multirow[b]{2}{*}{ Region } & \multirow[b]{2}{*}{ Fuel } & \multicolumn{3}{|c|}{$\begin{array}{c}\text { Capacity } \\
\text { (MW) }\end{array}$} & \multirow[b]{2}{*}{ COD } \\
\hline & & & Total & Domestic & Export & \\
\hline Nam Ka 1/2 & Central 1 & Hydro & 0.1 & 0.1 & & 2013 \\
\hline Nam Ngiep 3A & Central 1 & Hydro & 44.0 & 44.0 & & 2014 \\
\hline Tadlang (Nam Saen) & Central 1 & Hydro & 5.0 & 5.0 & & 2014 \\
\hline Nam Ngiep 2 & Central 1 & Hydro & 180.0 & 180.0 & & 2015 \\
\hline Nam Sana & Central 1 & Hydro & 14.0 & 14.0 & & 2015 \\
\hline Nam San 3B & Central 1 & Hydro & 45.0 & 45.0 & & 2015 \\
\hline Nam San 3A & Central 1 & Hydro & 69.0 & 69.0 & & 2016 \\
\hline Nam Mang 1 & Central 1 & Hydro & 64.0 & 64.0 & & 2016 \\
\hline Nam Kuen & Central 1 & Hydro & 0.0 & 0.0 & & 2016 \\
\hline Nam Song & Central 1 & Hydro & 3.0 & 3.0 & & 2016 \\
\hline Nam Ngiep 2C & Central 1 & Hydro & 14.6 & 14.6 & & 2017 \\
\hline Nam Phal & Central 1 & Hydro & 86.0 & 86.0 & & 2017 \\
\hline \multirow[t]{2}{*}{ Naxaythong Solar Farm } & Central 1 & Solar & 32.0 & 32.0 & & 2017 \\
\hline & & Central 1 & $1,653.1$ & 1038.1 & 615.0 & \\
\hline Theun-Hinboun & Central 2 & Hydro & 220.0 & & 220.0 & 1998 \\
\hline Nam Theun 2 & Central 2 & Hydro & $1,075.0$ & 75.0 & $1,000.0$ & 2010 \\
\hline Nam Phao & Central 2 & Hydro & 1.7 & 1.7 & & 2011 \\
\hline Nam Gnouang 8 & Central 2 & Hydro & 60.0 & 60.0 & & 2012 \\
\hline Tadsalen & Central 2 & Hydro & 3.2 & 3.2 & & 2012 \\
\hline Theun-Hinboun Extension & Central 2 & Hydro & 220.0 & 0.0 & 220.0 & 2012 \\
\hline \multirow[t]{2}{*}{ Mit Lao Biomass Factory } & Central 2 & Biomass & 5.0 & 5.0 & & 2012 \\
\hline & & Central 2 & $1,584.9$ & 144.9 & $1,440.0$ & \\
\hline Selabam & South & Hydro & 5.0 & 5.0 & & 1969 \\
\hline Xeset 1 & South & Hydro & 45.0 & 45.0 & & 1991 \\
\hline Houay Ho & South & Hydro & 152.0 & 2.0 & 150.0 & 1999 \\
\hline Xeset 2 & South & Hydro & 76.0 & 76.0 & & 2009 \\
\hline Houay Samong & South & Hydro & 0.1 & 0.1 & & 2013 \\
\hline Xekamman 3 & South & Hydro & 250.0 & 25.0 & 225.0 & 2013 \\
\hline Xe Namnoy 1 & South & Hydro & 14.8 & 14.8 & & 2013 \\
\hline Houg Anh Biomass Power House & South & Biomass & 20.0 & 20.0 & & 2015 \\
\hline Houay Lamphangnay & South & Hydro & 88.0 & 88.0 & & 2015 \\
\hline Xe Namnoy 6 & South & Hydro & 5.0 & 5.0 & & 2016 \\
\hline Xeset 3 & South & Hydro & 25.0 & 25.0 & & 2016 \\
\hline Xenamnoy 2-Xekatam 1 & South & Hydro & 10.0 & 10.0 & & 2017 \\
\hline Xekaman 1 & South & Hydro & 290.0 & 32.0 & 258.0 & 2017 \\
\hline \multirow[t]{3}{*}{ Nam Kong 2} & South & Hydro & 66.0 & 66.0 & & 2017 \\
\hline & & South & 1,046.9 & 413.9 & 633.0 & \\
\hline & & National & 6,969.6 & $2,503.6$ & 4,466.0 & \\
\hline
\end{tabular}

$\mathrm{COD}=$ commercial operation date, $\mathrm{MW}=$ megawatt.

Note: Numbers may not sum precisely because of rounding.

Sources: Government of the Lao People's Democratic Republic, Ministry of Energy and Mines. 2017. Electricity Statistics 2016. Vientiane; and Japan International Cooperation Agency. 2018. The Study on Power System Network Master Plan in Lao PDR. Presentation prepared for a preliminary meeting for power export scenario setting. Vientiane. April. 


\section{Appendix 3}

Key Transmission Projects Proposed in the Lao People's Democratic Republic

\begin{tabular}{|c|c|c|c|c|c|}
\hline \multirow[b]{2}{*}{ No. } & \multicolumn{2}{|c|}{ Domestic Transmission Line Projects } & \multirow{2}{*}{$\begin{array}{c}\text { Voltage } \\
(\mathrm{kV})\end{array}$} & \multirow{2}{*}{$\begin{array}{l}\text { Length } \\
(\mathrm{km})\end{array}$} & \multirow[b]{2}{*}{ COD } \\
\hline & From & To & & & \\
\hline \multicolumn{6}{|c|}{ North and Central 1 Regions } \\
\hline 1 & Thafa & Luangnamtha 1 & 115 & 91 & 2017 \\
\hline 2 & Thafa & Pha Oudom & 115 & 22 & 2017 \\
\hline 3 & Thafa & Houayxai & 115 & 51 & 2017 \\
\hline 4 & Xayabuli & Paklay & 115 & 123 & 2017 \\
\hline 5 & Paklay & Non Hai & 115 & 104 & 2017 \\
\hline 6 & Paklay & Ken Thao (Border) & 115 & 67 & 2017 \\
\hline 7 & Nam Ou 7 & Nam Ou 6 & 230 & 39 & 2020 \\
\hline 8 & Nam Ou 4 & Nam Ou 2 & 230 & 33 & 2020 \\
\hline 9 & Nam Ou 3 & Pak Mong & 230 & 33 & 2020 \\
\hline 10 & Hin Huep & Thalat 2 & 230 & 30 & 2017 \\
\hline 11 & Thalat 2 & $\mathrm{Na}$ Bong & 230 & 58 & 2017 \\
\hline 12 & Tha Bok & $\mathrm{Na}$ Bong & 230 & 23 & 2017 \\
\hline \multicolumn{6}{|c|}{ Central 2 and South Regions } \\
\hline 13 & Tha Vieng & Lak 20 & 230 & 220 & 2017 \\
\hline 14 & Ban Hat & Don Sahong HPP & 230 & 27 & 2019 \\
\hline
\end{tabular}

$\mathrm{COD}=$ commercial operation date, $\mathrm{HPP}=$ hydropower project, $\mathrm{km}=$ kilometer, $\mathrm{kV}=$ kilovolt.

\begin{tabular}{|c|c|c|c|c|c|}
\hline \multirow[b]{2}{*}{ No. } & \multicolumn{2}{|c|}{ Cross-Border Interconnection Projects } & \multirow{2}{*}{$\begin{array}{c}\text { Voltage } \\
\text { (kV) }\end{array}$} & \multirow[b]{2}{*}{ Status } & \multirow[b]{2}{*}{ Estimated $\mathrm{CO}$} \\
\hline & From & To & & & \\
\hline \multicolumn{6}{|c|}{ North Region } \\
\hline 1 & Paklay & Tha li (Thailand) & 115 & Under construction & 2018 \\
\hline 2 & Ton Pheung & Mae Chan (Thailand) & 115 & Proposed & $2020-2024$ \\
\hline 3 & Ton Pheung & Tachileck (Myanmar) & 115 & Proposed & $2020-2024$ \\
\hline 4 & M. Long & Shan State (Myanmar) & 230 & Planned & $2020-2025$ \\
\hline 5 & MK_Xayabuly & Loei 2 (Thailand) & 500 & Under construction & 2019 \\
\hline 6 & Na Mo & $\mathrm{Ban} \mathrm{Na}(\mathrm{PRC})$ & 500 & Under study & 2021 \\
\hline 7 & Muang Houn & Nan 2 (Thailand) & 500 & Planned & 2024 \\
\hline 8 & Xam Nuea & Nho Quan (Viet Nam) & --- & Under study & TBD \\
\hline \multicolumn{6}{|c|}{ South Region } \\
\hline 9 & Ban Hat & Stung Treng (Cambodia) & 230 & Proposed & TBD \\
\hline 10 & Ban Lak 25 & Ubon 3 (Thailand) & 500 & Under construction & 2019 \\
\hline 11 & Hat Xan & Plei ku (Viet Nam) & 500 & Under study & $2021-2025$ \\
\hline
\end{tabular}

$\mathrm{COD}=$ commercial operation date, $\mathrm{kV}=$ kilovolt, $\mathrm{PRC}=$ People's Republic of China, $\mathrm{TBD}=$ to be determined.

Source: Government of the Lao People's Democratic Republic, Ministry of Energy and Mines. 


\section{Appendix 4}

Pipeline of Hydropower Projects of the Lao People's Democratic Republic

Projects to be commissioned over 2018-2023 are the following:

\begin{tabular}{|c|c|c|c|c|c|c|}
\hline \multirow[b]{2}{*}{ Plant name } & \multirow[b]{2}{*}{ Region } & \multirow[b]{2}{*}{ Status } & \multirow[b]{2}{*}{ COD } & \multicolumn{3}{|c|}{$\begin{array}{l}\text { Capacity } \\
\text { (MW) }\end{array}$} \\
\hline & & & & Total & Domestic & Export \\
\hline Nam Peun 1 & North & Under construction & 2018 & 15.0 & 15.0 & \\
\hline Nam Sim & North & Under construction & 2018 & 9.0 & 9.0 & \\
\hline Nam Tha 1 & North & Under construction & 2018 & 168.0 & 168.0 & \\
\hline Nam Hao & North & Under construction & 2019 & 15.0 & 15.0 & \\
\hline Nam Mon 1 & North & Under construction & 2019 & 10.0 & 10.0 & \\
\hline Nam Dick 1 & North & Under construction & 2020 & 15.0 & 15.0 & \\
\hline Nam Ngao & North & Under construction & 2020 & 15.0 & 15.0 & \\
\hline Nam Ou 1 & North & Under construction & 2020 & 180.0 & 180.0 & \\
\hline Nam Ou 3 & North & Under construction & 2020 & 210.0 & 210.0 & \\
\hline $\mathrm{Nam} \mathrm{Ou} 4$ & North & Under construction & 2020 & 132.0 & 132.0 & \\
\hline Nam Ou 7 & North & Under construction & 2020 & 210.0 & 210.0 & \\
\hline Nam Tha 2 & North & Under construction & 2020 & 14.8 & 14.8 & \\
\hline Nam Xam 3 & North & Under construction & 2020 & 156.0 & 156.0 & \\
\hline Nam Xam 1 & North & PDA & 2020 & 75.0 & 75.0 & \\
\hline Nam Long New & North & Under construction & 2021 & 13.1 & 13.1 & \\
\hline Nam Ngum 4 & North & Under construction & 2021 & 240.0 & 240.0 & \\
\hline Nam Seung 1 & North & PDA & 2021 & 30.0 & 30.0 & \\
\hline Nam Ta Lan 2 & North & Under construction & 2021 & 5.0 & 5.0 & \\
\hline MK Pakbeng & North & PDA & 2022 & 912.0 & 114.0 & 798.0 \\
\hline Nam Pha & North & CA & 2022 & 180.0 & 180.0 & \\
\hline Nam Seung 2 & North & PDA & 2022 & 108.0 & 108.0 & \\
\hline \multirow[t]{2}{*}{ Nam Xam 4} & North & PDA & 2023 & 150.0 & 150.0 & \\
\hline & & North & & $2,862.9$ & $2,064.9$ & 798.0 \\
\hline Nam Chiene & Central 1 & Under construction & 2018 & 104.0 & 104.0 & \\
\hline Nam Aow (Nam Pot) & Central 1 & Under construction & 2018 & 15.0 & 15.0 & \\
\hline $\begin{array}{l}\text { Nam Ngum } 1 \\
\text { (extension phase) }\end{array}$ & Central 1 & Under construction & 2018 & 80.0 & 80.0 & \\
\hline Nam PhaGnai & Central 1 & Under construction & 2018 & 19.0 & 19.0 & \\
\hline
\end{tabular}


continued

\begin{tabular}{|c|c|c|c|c|c|c|}
\hline \multirow[b]{2}{*}{ Plant name } & \multirow[b]{2}{*}{ Region } & \multirow[b]{2}{*}{ Status } & \multirow[b]{2}{*}{ COD } & \multicolumn{3}{|c|}{$\begin{array}{l}\text { Capacity } \\
(\mathrm{MW})\end{array}$} \\
\hline & & & & Total & Domestic & Export \\
\hline MK Xayaboury & Central 1 & Under construction & 2019 & $1,285.0$ & 60.0 & $1,225.0$ \\
\hline Nam Houng Down & Central 1 & Under construction & 2019 & 12.5 & 12.5 & \\
\hline Nam Lik 1 & Central 1 & Under construction & 2019 & 64.0 & 64.0 & \\
\hline Nam Ngiep 1 (off-take) & Central 1 & Under construction & 2019 & 294.0 & & 294.0 \\
\hline Nam Ngiep 2A & Central 1 & Under construction & 2019 & 12.6 & 12.6 & \\
\hline Nam Ngiep 2B & Central 1 & Under construction & 2019 & 9.4 & 9.4 & \\
\hline Nam Ngiep Regulation & Central 1 & Under construction & 2019 & 18.0 & 18.0 & \\
\hline Nam The & Central 1 & Under construction & 2019 & 15.0 & 15.0 & \\
\hline Nam Mone & Central 1 & Under construction & 2020 & 6.0 & 6.0 & \\
\hline $\begin{array}{l}\text { Nam Ngum } 1 \\
\text { (extension phase) }\end{array}$ & Central 1 & Under construction & 2020 & 40.0 & 40.0 & \\
\hline Nam Ngum 3 & Central 1 & Under construction & 2020 & 480.0 & 480.0 & \\
\hline Nam Samoi & Central 1 & Under construction & 2020 & 5.0 & 5.0 & \\
\hline Nam Samuay & Central 1 & Under construction & 2020 & 5.0 & 5.0 & \\
\hline Kengseuaten & Central 1 & CA & 2021 & 54.0 & 54.0 & \\
\hline Nam Chee 1 & Central 1 & PDA & 2021 & 5.0 & 5.0 & \\
\hline Nam Chee 2 & Central 1 & PDA & 2021 & 7.9 & 7.9 & \\
\hline Nam Mat (Xieng Kuang) & Central 1 & PDA & 2021 & 15.0 & 15.0 & \\
\hline Nam Mat 1 & Central 1 & PDA & 2021 & 15.0 & 15.0 & \\
\hline Nam Chat 2 & Central 1 & PDA & 2022 & 8.0 & 8.0 & \\
\hline Nam Ken & Central 1 & PDA & 2022 & 5.0 & 5.0 & \\
\hline Nam Mo 2 & Central 1 & CA & 2022 & 120.0 & 120.0 & \\
\hline Nam Ngum Keng Kaun & Central 1 & Under construction & 2022 & 1.0 & 1.0 & \\
\hline Nam Phoun & Central 1 & PPA & 2022 & 45.0 & 45.0 & \\
\hline Nam Sor (Borikhamxai) & Central 1 & PPA & 2022 & 5.0 & 5.0 & \\
\hline Nam Theun 1 & Central 1 & Under construction & 2022 & 650.0 & 130.0 & 520.0 \\
\hline Nam Bak 1 & Central 1 & PDA & 2023 & 160.0 & 160.0 & \\
\hline Nam Mo 1 (Nam Kan) & Central 1 & PDA & 2023 & 60.0 & 60.0 & \\
\hline Nam Mouan & Central 1 & Feasibility study & 2023 & 100.0 & 100.0 & \\
\hline Nam Phouan & Central 1 & PDA & 2023 & 52.8 & 52.8 & \\
\hline \multirow[t]{2}{*}{ Nam Poui } & Central 1 & PDA & 2023 & 60.0 & 60.0 & \\
\hline & & Central 1 & & $3,828.2$ & $1,789.2$ & $2,039.0$ \\
\hline Nam Hinboun & Central 2 & Under construction & 2018 & 30.0 & 30.0 & \\
\hline Nam Hinboun (Down) & Central 2 & Under construction & 2020 & 15.0 & 15.0 & \\
\hline Tadsakhoy & Central 2 & PDA & 2021 & 30.0 & & 30.0 \\
\hline $\begin{array}{l}\text { Xebanghieng 2A } \\
\text { Tatsakhoy }\end{array}$ & Central 2 & PDA & 2021 & 30.0 & 30.0 & \\
\hline \multirow[t]{2}{*}{ Xelanong 1} & Central 2 & Under construction & 2021 & 70.0 & 70.0 & \\
\hline & & Central 2 & & 175.0 & 145.0 & 30.0 \\
\hline
\end{tabular}


continued

\begin{tabular}{|c|c|c|c|c|c|c|}
\hline \multirow[b]{2}{*}{ Plant name } & \multirow[b]{2}{*}{ Region } & \multirow[b]{2}{*}{ Status } & \multirow[b]{2}{*}{ COD } & \multicolumn{3}{|c|}{$\begin{array}{c}\text { Capacity } \\
(\mathrm{MW})\end{array}$} \\
\hline & & & & Total & Domestic & Export \\
\hline Xekaman-Xanxai & South & Under construction & 2018 & 32.0 & 32 & \\
\hline Xeset-Houaytapong & South & CA & 2018 & 13.0 & 13 & \\
\hline Houay pow & South & Under construction & 2019 & 15.0 & 15.0 & \\
\hline MK. Donsahong & South & Under construction & 2019 & 260.0 & 260.0 & \\
\hline Xeplen-Xenamnoy & South & Under construction & 2019 & 410.0 & 40.0 & 370.0 \\
\hline Xeset-Kengxan & South & Under construction & 2019 & 13.0 & 13.0 & \\
\hline Dakcha Liew 1 & South & PPA & 2020 & 11.0 & 11.0 & \\
\hline Dakcha Liew 2 & South & PPA & 2020 & 13.0 & 13.0 & \\
\hline Houay Chiae & South & Under construction & 2020 & 8.0 & 8.0 & \\
\hline Houay Pa Gnoo Down & South & PDA & 2020 & 15.0 & 15.0 & \\
\hline Xekatam & South & PDA & 2020 & 81.0 & 81.0 & \\
\hline Xekong (Downstream) A & South & PDA & 2020 & 76.0 & 76.0 & \\
\hline Houay Palai & South & Under construction & 2021 & 26.0 & 26.0 & \\
\hline Houay Phok & South & PPA & 2021 & 12.0 & 12.0 & \\
\hline Houay Yoi-Houaykod & South & Under construction & 2021 & 15.0 & 15.0 & \\
\hline Houaylay & South & PDA & 2021 & 3.0 & 3.0 & \\
\hline Nam kong 1 & South & PPA & 2021 & 160.0 & 160.0 & \\
\hline Nam Kong 3 & South & CA & 2021 & 45.0 & 45.0 & \\
\hline Nam Pak & South & PDA & 2021 & 150.0 & 150.0 & \\
\hline Houay kaphuek Down & South & PDA & 2022 & 7.0 & 7.0 & \\
\hline Houay La Nge & South & PDA & 2022 & 60.0 & 60.0 & \\
\hline Houy Palal down & South & Under construction & 2022 & 4.0 & 4.0 & \\
\hline Houykapheu 1 & South & Under construction & 2022 & 5.0 & 5.0 & \\
\hline Nam Bi 1 & South & PDA & 2022 & 50.0 & 50.0 & \\
\hline Nam Bi 2 & South & PDA & 2022 & 68.0 & 68.0 & \\
\hline Nam Bi 3 & South & PDA & 2022 & 12.0 & 12.0 & \\
\hline Sekong 5 & South & Feasibility study & 2022 & 330.0 & 330.0 & \\
\hline Xekong 4A & South & MOU & 2022 & 175.0 & & 175.0 \\
\hline Xekong 4B & South & MOU & 2022 & 165.0 & & 165.0 \\
\hline Xelanong 2 & South & PDA & 2022 & 35.0 & 35.0 & \\
\hline Houay Champi & South & PDA & 2023 & 5.0 & 5.0 & \\
\hline Xekaman 2B & South & Feasibility study & 2023 & 185.0 & 185.0 & \\
\hline Xekaman 4 & South & PDA & 2023 & 70.0 & 70.0 & \\
\hline \multirow[t]{3}{*}{ Xenamnoy 5} & South & PDA & 2023 & 5.0 & 5.0 & \\
\hline & & South & & $2,534.0$ & $1,824.0$ & 710.0 \\
\hline & & National & & $9,400.1$ & $5,823.1$ & $3,577.0$ \\
\hline
\end{tabular}

$\mathrm{CA}=$ construction agreement, $\mathrm{COD}=$ commercial operation date, $\mathrm{MOU}=$ memorandum of understanding, $\mathrm{MW}=$ megawatt, $\mathrm{PDA}=$ project development agreement.

Sources: Government of the Lao People's Democratic Republic, Ministry of Energy and Mines. 2017. Electricity Statistics 2016. Vientiane; and Japan International Cooperation Agency. 2018. The Study on Power System Network Master Plan in Lao PDR. Presentation prepared for a preliminary meeting for power export scenario setting. Vientiane. April. 


\title{
Appendix 5
}

\author{
Laws and Regulations for Power Project Development \\ in the Lao People's Democratic Republic
}

Salient laws and regulations pertaining to the development of power projects in the Lao PDR:

Law/Regulation

The Lao Land Law (1997)

of Cultural, Historical, and

Natural Heritage (1997)

Forestry Law (2007 revision)

Constitution of

the Lao People's

Democratic Republic

(2003 and 2015 revisions)

Environmental

Protection Law

(2012 and 2013 revisions)

Water and Water Resource Law (1996 and 2013)

\section{Aspects Relating to Electricity Generation}

Stipulation of land as a state-owned asset and provision of rights for its utilization, lease, transfer, and inheritance

Subsequent regulations relate to the expropriation of land and compensation (Decree on Compensation and Resettlement No. 192/PM 2005), as well as the compensation and relocation for those displaced by development projects (Regulation for the Agreement on Lao National Environmental Standards, 2010).

Designation of national heritage areas that require preservation (Articles 5 and 8)

Stipulation of natural forests and forested areas being state-owned assets

Note that the Lao PDR's Forestry Strategy to the Year 2020, tabled as a project to meet its INDC commitments, seeks to increase forest cover to 70\% of total land area by 2020.

Revised in 2003 (Article 19) to state that there is a national obligation to protect the environment and natural resources

Further revised in 2015 (Article 17) to increase the authority of the state, such that "natural resources such as land, minerals, water, air, forest, non-timber forest products, aquatic organisms, and wildlife are owned by the national community represented by the government, and the State ensures the rights to use, transfer and inherit them nationwide in accordance with the laws."

Enacted in 1999 as a law "embodying Article 19 of the constitution" of the Lao PDR, requiring environmental assessment for any projects that affect, conserve, or utilize natural resources Later expanded from 2010 onward to include specific requirements, regulations, and guidelines for the environmental assessments (In particular, the Decree on Environmental Impact Assessment (2010) set out that any hydropower project above $15 \mathrm{MW}$ requires an environmental impact assessment, with those projects less than $15 \mathrm{MW}$ requiring an initial environmental examination.)

2013 revision states that a strategic environmental assessment is required when developing policies, strategic plans, and programs in the energy sector.

The imposition of a service fee for water use was introduced in December 2015, equating to $5 \%$ or more of total income from all export-oriented hydropower projects and domestic hydropower projects exceeding $15 \mathrm{MW}$. Those domestic hydropower projects less than 15 $\mathrm{MW}$ are subject to a water usage fee of $5 \%$ of total income.

The Water and Water Resource Law was due to be revised in April 2017 to reflect data and information gathering requirements pertaining to the use of hydrological resources (e.g., in electricity generation).

INDC = intended nationally determined contribution, Lao PDR = Lao People's Democratic Republic, MW = megawatt.

Source: Government of the Lao People's Democratic Republic, Ministry of Energy and Mines. 


\section{Lao People's Democratic Republic Energy Sector Assessment, Strategy, and Road Map}

Expanded access to modern and affordable sources of energy and more efficient use of energy resources are needed for the Lao People's Democratic Republic to achieve its development goals. This publication provides an overview of the country's energy sector, examines its performance, the challenges it faces, and the government's energy strategy. It also reflects on lessons learned from past Asian Development Bank assistance and proposes potential areas for future support.

\section{About the Asian Development Bank}

ADB is committed to achieving a prosperous, inclusive, resilient, and sustainable Asia and the Pacific, while sustaining its efforts to eradicate extreme poverty. Established in 1966, it is owned by 68 members

-49 from the region. Its main instruments for helping its developing member countries are policy dialogue, loans, equity investments, guarantees, grants, and technical assistance. 